no.

GL-91-13

c. 3

Corps neers
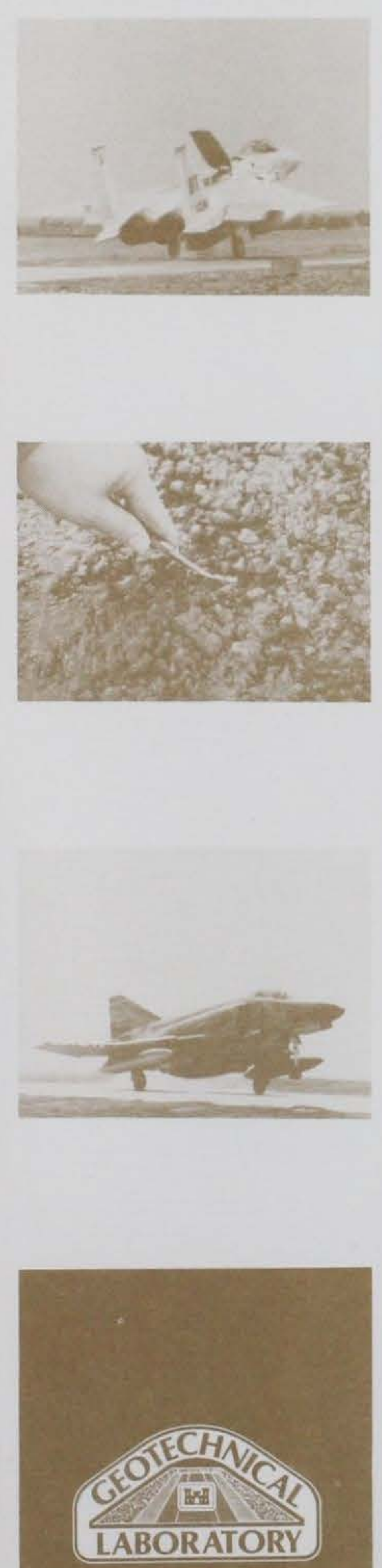

\section{INVESTIGATION OF AIRFIELD RUNWAYS AT JACKSONVILLE NAVAL AIR STATION}

by

Randy C. Ahlrich

Geotechnical Laboratory

DEPARTMENT OF THE ARMY

Waterways Experiment Station, Corps of Engineers

3909 Halls Ferry Road, Vicksburg, Mississippi 39180-6199

\section{US-CE-C Profegr OF THE \\ UNITED STATES GOVERNMENT}

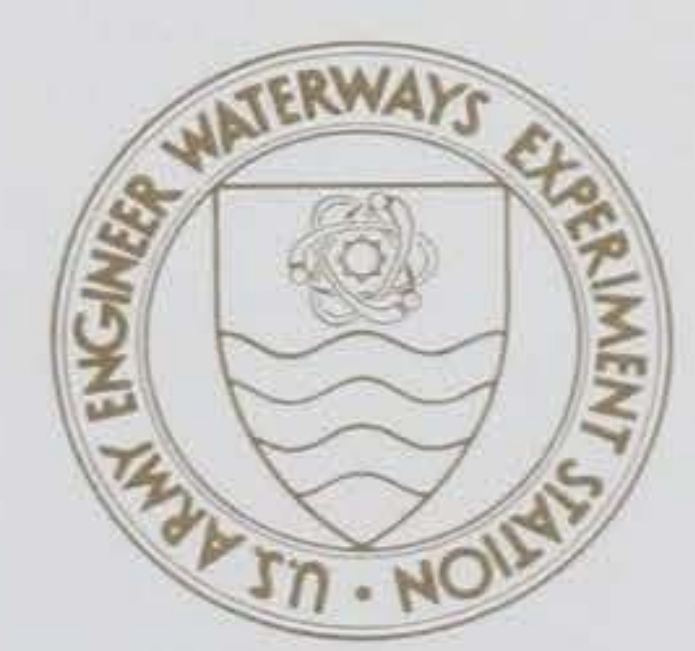

June 1991

Final Report

Approved For Public Release; Distribution Unlimited

\author{
RESEARCH LIBRARY \\ US ARMY ENGINEER WATERWAYS \\ EXPERIMENT STATION \\ VICKSBURG, MISSISSIPPI
}


Public reporting burden for this collection of information is estimated to average 1 hour per response, including the time for reviewing instructions, searching existing data sources, gathering and maintaining the data needed, and completing and reviewing the collection of information. Send comments regarding this burden estimate or any other aspect of this Davis Highway. Suite 1204. Arlington, VA 22202-4302, and to the Office of Management and Budget, Paperwork Reduction Project (0704-0188), Washington, DC 20503.
Dis lefferson

\begin{tabular}{|l|c|c|}
\hline 1. AGENCY USE ONLY (Leave blank) & $\begin{array}{c}\text { 2. REPORT DATE } \\
\text { June } 1991\end{array}$ & $\begin{array}{c}\text { 3. REPORT TYPE AND DATES COVERED } \\
\text { Final report }\end{array}$
\end{tabular}

4. TITLE AND SUBTITLE

Investigation of Airfield Runways at

Jacksonville Naval Air Station

\section{AUTHOR(S)}

Randy C. Ahlrich

\section{PERFORMING ORGANIZATION NAME(S) AND ADDRESS(ES)}

USAE Waterways Experiment Station

Geotechnical Laboratory

3909 Halls Ferry Road

Vicksburg, MS 39180-6199

9. SPONSORING / MONITORING AGENCY NAME(S) AND ADDRESS(ES)

\section{FUNDING NUMBERS}

8. PERFORMING ORGANIZATION

REPORT NUMBER

Miscellaneous Paper GL $-91-13$

Naval Facilities Engineering Command, Southern Division

2155 Eagle Drive

Charleston, SC 29411-0068

\section{SUPPLEMENTARY NOTES}

Available from the National Technical Information Service, 5285 Port Royal Road, Springfield, VA 22161

12a. DISTRIBUTION/AVAILABILITY STATEMENT

12b. DISTRIBUTION CODE

Approved for public release; distribution unlimited

\section{ABSTRACT (Maximum 200 words)}

In October 1990, the US Army Engineer Waterways Experiment Station (WES) was requested by the Naval Facilities Engineering Command, Southern Division, Charleston, South Carolina, to provide technical assistance in analyzing the airfield pavement distresses at Jacksonville Naval Air Station in Florida. Runways $9 / 27$ and $14 / 32$ had been rehabilitated and resurfaced with asphalt concrete in 1988. Within 1 year, significant amounts of loose fine aggregate appeared on the pavement surface. The asphalt concrete had begun to prematurely deteriorate and exhibit pavement surface distresses. The primary surface distresses were an open-textured surface, raveling, and the evidence of roots in the asphalt concrete.

14. SUBJECT TERMS Airfield pavement Asphalt concrete

Field compaction

\section{SECURITY CLASSIFICATION OF REPORT}

Unclassified
Gradations

Gyratory Testing Machine

In-place voids

18. SECURITY CLASSIFICATION OF THIS PAGE

Unclassified

19. SECURITY CLASSIFICATION OF ABSTRACT

Unclassified 


\section{3. (Concluded).}

The Materials Research and Construction Technology branch of the Geotechnical Laboratory at WES was requested to inspect the airfield pavements and perform laboratory tests on asphalt concrete samples to determine properties of the asphalt cement, aggregates, and asphalt concrete mixture. The purpose of this analysis was to evaluate the in-place materials for compliance with specifications, determine possible causes for these pavement distresses, and recommend options for the repair of the airfield pavements.

The laboratory evaluation of the asphalt concrete material indicated that pavement raveling was due to an improperly produced and constructed asphalt concrete mixture. Several factors that contributed to this improper asphalt mixture were: (a) field density and compaction results were low and below minimum compaction requirements, (b) aggregate gradations were consistently out of specification, (c) natural sand contents were extremely high, (d) inplace asphalt contents were extremely low, and (e) void properties did not meet standard criteria for airfield pavements.

14. (Concluded).

Natural sand

Raveling

Recompaction analysis 


\section{PREFACE}

This pavement investigation was conducted by the Geotechnical Laboratory (GL), US Army Engineer Waterways Experiment Station, Vicksburg, Mississippi, for the Naval Facilities Engineering Command (NFEC), Southern Division, Charleston, South Carolina, to provide technical assistance in analyzing the pavement at Jacksonville Naval Air Station in FLorida. This study was authorized by the Jacksonville Naval Air Station in MIPR N0020791MIPR001. This work was conducted from October 1990 to March 1991. The Technical Monitors were Messrs. Ray Pearre, Bill Woodard, and Wilbert Beverly of NFEC, Southern Division.

The study was conducted under the general supervision of Dr. William F. Marcuson III, Chief, GL, and Mr. Harry H. Ulery, Jr., Chief, Pavement Systems Division (PSD). This report was written under direction supervision of Mr. Timothy W. Vollor, Acting Chief, Material Research and Construction Technology Branch, PSD. PSD personnel engaged in the sampling, testing, evaluating, and analyzing this project included Messrs. Jerry Duncan, Herbert McKnight, Tim McCaffrey, David Reed, and Joey Simmons. The project Principal Investigator was $\mathrm{Mr}$. Randy $\mathrm{C}$. Ahlrich who also wrote the report.

The Commander and Director of WES during the conduct of the project and preparation of this report was COL Larry B. Fulton, EN. The Technical Director was Dr. Robert W. Whalin. 
CONTENTS

Page

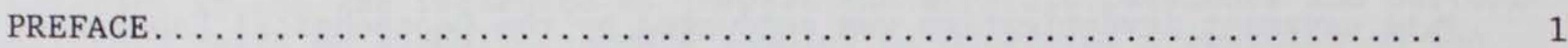

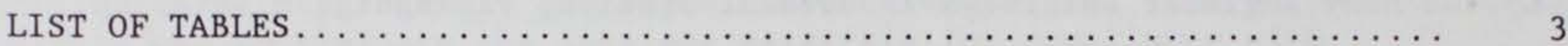

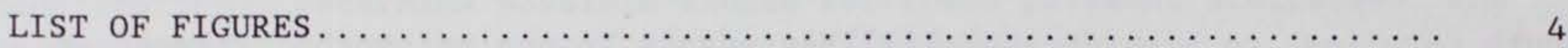

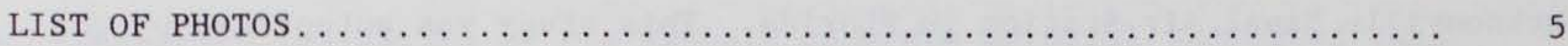

CONVERSION FACTORS, NON-SI TO SI (METRIC) UNITS OF MEASUREMENT....... 6

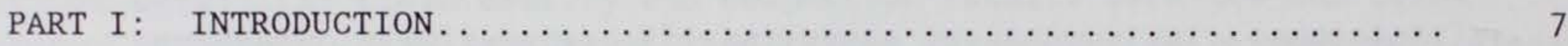

PART II: ANALYSIS OF PAVEMENT MATERIALS $\ldots \ldots \ldots \ldots \ldots \ldots \ldots \ldots \ldots \ldots \ldots$

PART III: DISCUSSION OF LABORATORY RESULTS $\ldots \ldots \ldots \ldots \ldots \ldots \ldots \ldots \ldots \ldots$

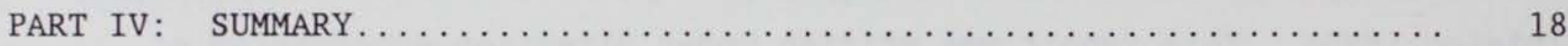

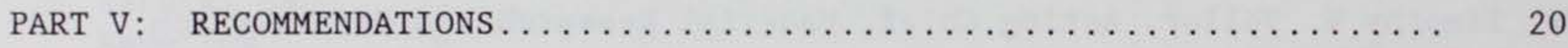

APPENDIX A: FIELD INSPECTION OF AIRFIELD RUNWAYS AT JACKSONVILLE NAS.. A1

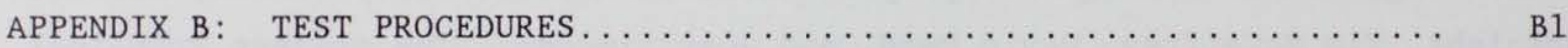




\section{LIST OF TABLES}

No.

1 Slab Location and Pavement Surface Characteristics........... 8

2 Laboratory Test Plan............................ 10

3 Pavement Thickness and Field Density Results............. 21

4 Surface Course Aggregate Analysis - Runway $9 / 27 \ldots \ldots \ldots \ldots \ldots \ldots 22$

5 Surface Course Aggregate Analysis - Runway $14 / 32 \ldots \ldots \ldots \ldots \ldots 23$

6 Recovered Asphalt Cement Analysis...................... 24

7 Surface Course Mixture Recompaction Analysis - Runway 9/27, $290^{\circ} \mathrm{F}$ Compaction Temperature - 75 Blow Hand Hammer ......... 25

8 Surface Course Mixture Recompaction Analysis - Runway 14/32, $290^{\circ} \mathrm{F}$ Compaction Temperature - 75 Blow Hand Hammer ......... 26

9 Surface Course Mixture Recompaction Analysis - Runway 9/27, $250^{\circ} \mathrm{F}$ Compaction Temperature - 75 Blow Hand Hammer ......... 27

10 Surface Course Mixture Recompaction Analysis - Runway 14/32, $250^{\circ} \mathrm{F}$ compaction Temperature - 75 Blow Hand Hammer ......... 28

11 Gyratory Analysis of Surface Course Mixture - Runway 9/27 . . . . 29

12 Gyratory Analysis of Surface Course Mixture - Runway 14/32 . . . 30

13 Effect of Moisture on Surface Course Mixture.............. 31

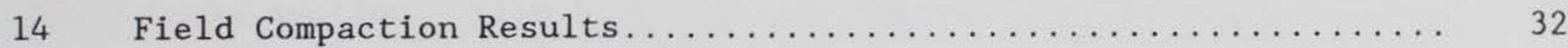

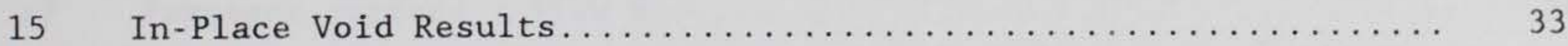




\section{LIST OF FIGURES}

No.

$\underline{\text { Page }}$

1 Layout of slab sample locations for Runway $9 / 27$ and $14 / 32 \ldots \ldots 34$

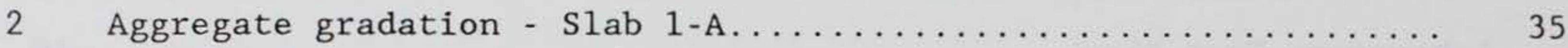

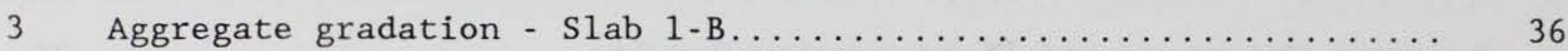

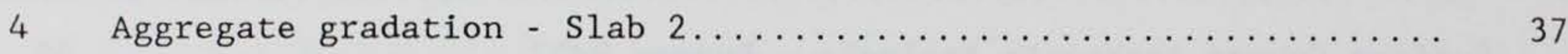

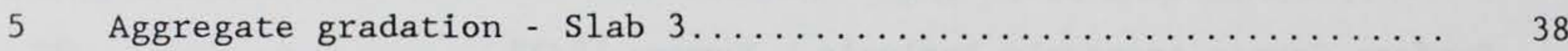

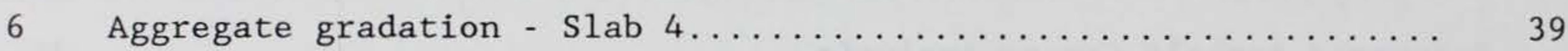

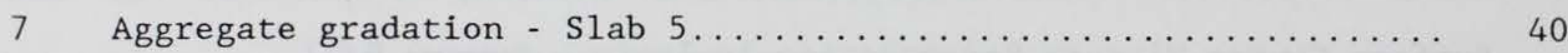

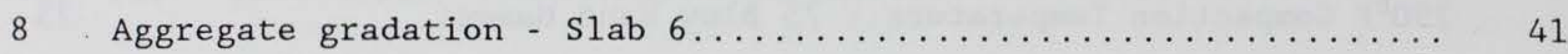

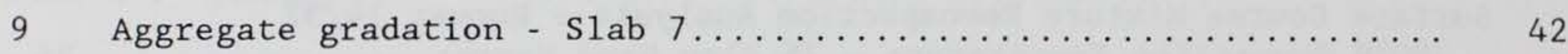

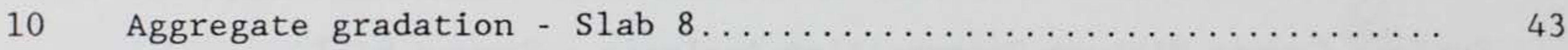




\section{LIST OF PHOTOS}

No.

$\underline{\text { Page }}$

1 Typical slab sample dimensions..................... 44

2 Concrete saw used to remove slab samples................. 44

3 Typical view of removed slab sample.................. 45

4 Overall view of eight slab samples.................. 45

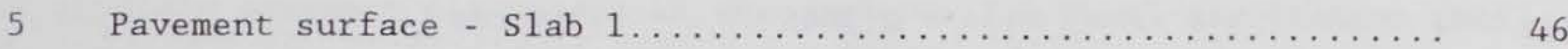

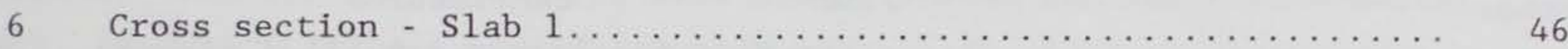

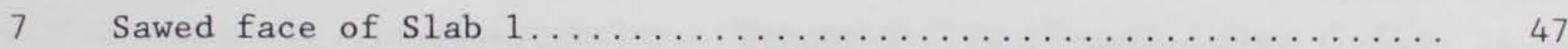

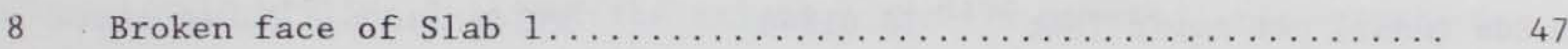

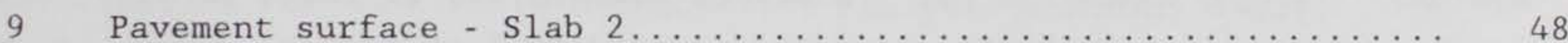

$10 \quad$ Cross section $-\mathrm{Slab} 2 \ldots \ldots \ldots \ldots \ldots \ldots \ldots \ldots \ldots \ldots \ldots \ldots \ldots \ldots$

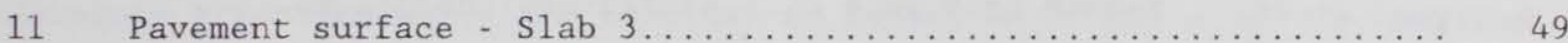

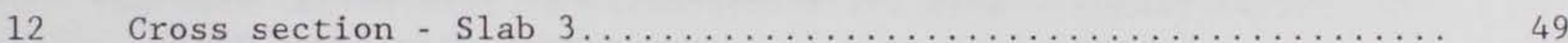

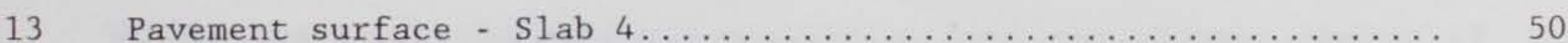

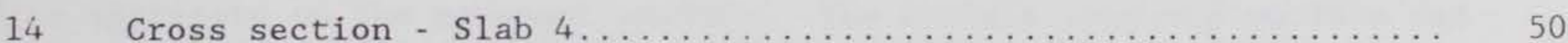

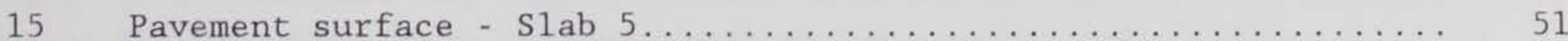

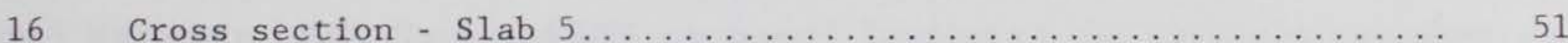

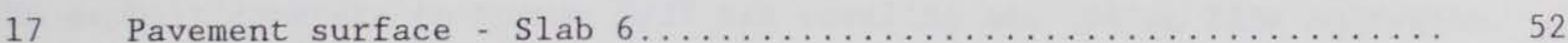

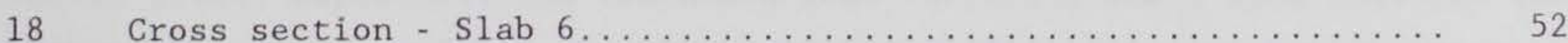

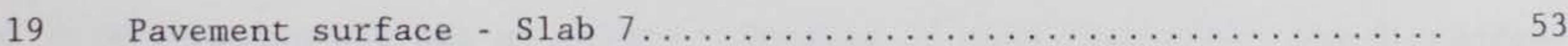

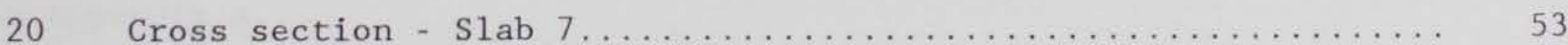

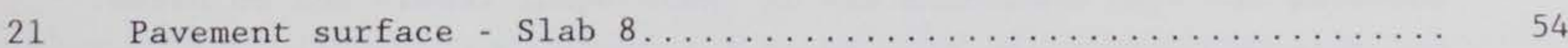

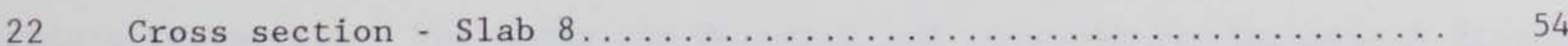




\section{CONVERSION FACTORS, NON-SI TO SI (METRIC) \\ UNITS OF MEASUREMENT}

Non-SI units of measurement used in this report can be converted to SI (metric) units as follows:

\section{Multiply}

degrees (angle)

Fahrenheit degrees

feet

inches

pounds (force)

pounds (force) per square inch pounds (mass) per cubic foot
By

0.01745329

$5 / 9$

0.3048

2.54

4.448222

6.894857

16.01846
To Obtain

radians

Celsius degrees or Kelvins* metres

centimetres

newtons

kilopascals

kilograms per cubic metre

* To obtain Celsius (C) temperature readings from Fahrenheit (F) readings, use the following formula: $C=(5 / 9)(F-32)$. To obtain Kelvin $(K)$ readings, use: $\mathrm{K}=(5 / 9)(\mathrm{F}-32)+273.15$. 


\section{Investigation of Airfield Runways at Jacksonville \\ Naval Air Station}

\section{PART I: INTRODUCTION}

The U.S. Army Engineer Waterways Experiment Station (WES) was requested by the Southern Division, Naval Facilities Engineering Command, Charleston, South Carolina, in October 1990, to provide technical assistance in analyzing the airfield pavement distresses at the Jacksonville Naval Air Station (NAS), Florida. Runways $9 / 27$ and $14 / 32$ were rehabilitated and resurfaced during 1988. Runway $14 / 32$ was resurfaced with an asphalt slurry seal followed by a 1-1/2-in. asphalt concrete overlay. The rehabilitation of Runway $9 / 27$ included cold milling $3 \mathrm{in}$. of the existing asphalt pavement and resurfacing with $2-1 / 2$ to 6 in. of new asphalt concrete. Two different asphalt concrete mix designs were used during the rehabilitation of Runways $9 / 27$ and 14/32. The asphalt concrete mixture placed on Runway $9 / 27$ had a 3/4-in.-maximum size aggregate gradation while the material on Runway $14 / 32$ had a $1 / 2$-in.-maximum size aggregate gradation. The rehabilitation project was completed in December 1988 .

Within one year, the airfield manager noticed significant amounts of fine aggregate on the pavement surface. The asphalt concrete surface had begun to deteriorate and showed surface distresses. The primary surface distresses were raveling and the evidence of roots in the asphalt concrete. On 6 November 1990, Navy and WES personnel inspected the airfield pavement. The asphalt concrete on Runway $9 / 27$ was raveling and losing fine aggregate. Traffic areas, especially the touchdown zone, were extremely open-textured and exhibiting severe raveling. Runway $14 / 32$ had similar defects, but the degree of deterioration was not as severe. Details of site inspection are discussed in Appendix A.

Based on the visual inspection, it was concluded that the pavement deterioration was caused by several factors that dealt with material and mixture properties. The Materials Research and Construction Technology Branch of the Geotechnical Laboratory was requested by Jacksonville NAS to perform laboratory tests on asphalt concrete samples to determine properties of the asphalt cement, aggregate, and asphalt concrete mixture. The purpose of this 
analysis was to evaluate the in place materials for compliance with specifications, determine possible causes for these pavement distresses, and recommend options for the repair of the airfield pavement.

On 15 December 1990, eight slab samples approximately $2 \mathrm{ft}$ by $2 \mathrm{ft}$ in size were extracted from Runways $9 / 27$ and 14/32. Six samples were obtained from Runway 9/27, and two samples were obtained from Runway 14/32. These slab samples were selected in order to evaluate typical asphalt concrete materials throughout the airfield pavement. The individual slab sample location and pavement surface characteristics are listed in Table 1 and shown in Figure 1.

Table 1 .

\section{Slab Location and Pavement Surface Characteristics}

\begin{tabular}{|c|c|c|c|c|c|}
\hline$\underline{\mathrm{S} l a b}$ & Runway & $\underline{\text { Station }}$ & $\begin{array}{c}\text { Centerline } \\
\text { Offset } \\
\text { (ft) } \\
\end{array}$ & $\begin{array}{c}\text { Amount of } \\
\text { Traffic }\end{array}$ & $\begin{array}{c}\text { Visual Pavement } \\
\text { Surface Condition }\end{array}$ \\
\hline 1 & $9 / 27$ & $109+05$ & $15 \mathrm{~L}$ & $\begin{array}{l}\text { Heavy } \\
\text { Touchdown Zone }\end{array}$ & $\begin{array}{l}\text { Raveled, open-textured } \\
\text { excessive rubber } \\
\text { buildup }\end{array}$ \\
\hline 2 & $9 / 27$ & $109+85$ & $80 \mathrm{R}$ & Low & Good \\
\hline 3 & $9 / 27$ & $132+72$ & $28 \mathrm{~L}$ & Medium & Raveled \\
\hline 4 & $9 / 27$ & $145+13$ & $4 \mathrm{~L}$ & Heavy & Raveled, open-textured \\
\hline 5 & $9 / 27$ & $165+97$ & $65 \mathrm{~L}$ & Low & Raveled \\
\hline 6 & $9 / 27$ & $146+26$ & $34 \mathrm{R}$ & Medium & Raveled, open-textured \\
\hline 7 & $14 / 32$ & - & $80 \mathrm{~L}$ & Low & S1ightly raveled \\
\hline 8 & $14 / 32$ & - & $2 \mathrm{~L}$ & Heavy & Good \\
\hline
\end{tabular}

The slab samples were removed by full-depth saw cutting. This process produced asphalt concrete slabs with approximate dimensions of $2 \mathrm{ft}$ by $2 \mathrm{ft}$ with a depth equivalent to the full depth of the asphalt concrete surfacing. These samples were easily separated from the compacted granular limerock base course and shipped to the WES laboratories. During removal of the slab samples, voids throughout the surface course layer were evident, especially at the bottom of the wearing surface. Typical scenes of the slab removal are shown in Photos 1-3. 
On 17 December 1990, the eight slab samples arrived at the WES pavement laboratory. The samples were intact and undamaged from shipping. Photos 4-22 show the condition of the pavement samples upon arrival at wES prior to testing. Photos 5, 11, 13, 15, 17, and 19 show that surface raveling had occurred in these pavement slab samples. Photos $6,7,12,14,16,18$, and 20 show a large number of internal voids in asphalt concrete mixture. 


\section{PART II: ANALYSIS OF PAVEMENT MATERIALS}

Due to the nature of the pavement distresses, primarily surface raveling, only the surface course material was tested and analyzed. The laboratory test plan used to evaluate these slab samples is listed in Table 2. The test method designations and titles applicable to this laboratory study are listed in Appendix B.

Table 2

\section{Laboratory Test Plan}

1. Conduct the following tests on slab samples:
a. Thickness
b. Field density (MIL STD 620B, Method 101)
c. Asphalt extraction (ASTM D2172)
d. Recompaction analysis (ASTM D1559, D3387, MIL STD 620B, Method 100)
e. Abson recovery (ASTM D1856)
f. Aggregate tests

2. Conduct the following tests on recovered asphalt cement:
a. Penetration (ASTM D5)
b. Absolute viscosity (ASTM D2171)
c. Kinematic viscosity (ASTM D2170)
d. Ductility (ASTM D113)
e. Specific gravity (ASTM D70)

3. Conduct the following tests on the recovered aggregate material:
a. Specific gravity (ASTM C127, C128)
b. Absorption (ASTM C127, C128)
c. Percent fractured faces
d. Natural sand content
e. LA abrasion (ASTM C131)
f. Gradation (ASTM C117, C136)

4. Determine the following properties on the recompacted asphalt concrete mixture:
a. Marshal1 stability and flow (ASTM D1559, MIL STD 620B, Method 100)
b. Voids total mix (MIL STD 620B, Method 101)
c. Voids filled with asphalt (MIL STD 620B, Method 101)
d. Voids in mineral aggregate (MIL STD 620B, Method 101)
e. Recompacted density (ASTM D1559, D3387, MIL STD 620B, Method 100)
f. Retained stability (MIL STD 620B, Method 104)
g. Theoretical density (ASTM D2041, MIL STD 6208, Method 101)
h. Gyratory analysis (ASTM D3387)
i. Effect of moisture (ASTM D4867) 
The first step in evaluating the in-place material was to determine the thickness of the entire slab and then the surface course layer. Three 4-in. cores were taken from each slab sample so that the in-place field density could be determined (MIL STD 620B, Method 101). Pavement thickness and in place field density values are listed in Table 3.

Prior to any material testing, the surface course layer for each individual slab was separated from the remaining pavement layers. All loose material that had broken off of the slab samples was discarded and not tested. The next step in preparing the asphalt concrete material was to trim and remove all cut edges from the samples. This was accomplished by heating the cut edges and removing at least $3 / 4 \mathrm{in}$. of material with a hot spatula. This procedure is performed to ensure that the aggregate gradation is not affected by the sampling technique and that a true representative sample is evaluated. After this sample preparation was completed, the material representing individual slabs was broken down and thoroughly mixed before testing.

A complete laboratory analysis was conducted on each of the eight slab samples. Due to the condition of Slab 1 (Photos 5-8), two separate sets of tests were conducted for the raveled and nonraveled portions of the slab. A total of nine individual samples were evaluated. The laboratory evaluation for each sample included extractions, asphalt recoveries, recompaction analyses, and material tests.

Four asphalt extractions (ASTM D2172), two aggregate gradations (ASTM C136 and C117) and one Abson recovery (ASTM D1586) were conducted on each individual slab sample. Extractions and recoveries were conducted on splitout representative samples. Technical grade trichloroethylene and a two-stage extraction procedure using a high-speed centrifuge were employed to optimize the results of this procedure. The aggregates from this procedure were used to conduct aggregate gradation, specific gravity, fractured face, natural sand content, and LA abrasion tests. These results are summarized in Tables 4-5. The asphalt cements recovered from the Abson recovery procedure were used to conduct penetration, viscosity, specific gravity, and ductility tests. The results of these tests are listed in Table 6 . The aggregate gradations from the in-place material are compared to the job-mix-formula (JMF) provided by the contractor and the JMF tolerances in Figures 2-10. 
The remaining material from each slab sample was then used for a recompaction analysis. Three different compaction procedures were used to recompact the asphalt concrete material. The first procedure used was in accordance with ASTM D1559 which required a compaction temperature of $290^{\circ} \mathrm{F}$ and a compactive effort of 75 blows on each side with a hand hammer. The second compaction procedure followed the guidelines in MIL STD 620B, Method 100 , which required a compaction temperature of $250^{\circ} \mathrm{F}$ and a compactive effort of 75 blows on each side with the hand hammer. The third compaction procedure was conducted according to ASTM D3387 which uses the Corps of Engineers gyratory testing machine (GTM). The GTM was used to compact asphalt specimens at $250^{\circ} \mathrm{F}$ using $200 \mathrm{psi}, 30$ revolutions, and 1 -degree gyration angle, which is equivalent to a 75-blow hand hammer compactive effort.

The specimens produced by the three compaction procedures were used to determine standard Marshall mix design properties which include density, stability, flow, and void requirements. The results of these recompaction analyses are listed in Tables 7-12. Recompacted specimens were also evaluated using ASTM D4867 and MIL STD 620B, Method 104. These tests evaluated the effect of moisture on the asphalt concrete materials, and the results are listed in Tables 9,10 , and 13 . 
Asphalt concrete thickness and field density. The asphalt concrete thickness and field density results are listed in Tables 3, 14, and 15 . The total asphalt concrete pavement thicknesses for Runway 9/27 varied between 4-3/4 in. and $8 \mathrm{in}$. with the average thickness being approximately $6-1 / 4 \mathrm{in}$. The total asphalt concrete thicknesses of the two slab samples from Runway $14 / 32$ were $6-1 / 2$ in. and 5-3/4 in. The surface course layer thickness for Runway $9 / 27$ varied between $1-1 / 8$ in. and 1-3/4 in. The surface course thicknesses for Runway 14/32 were 1-3/8 in. and 1-7/8 in. Based on the absence of pavement structural failures, the thicknesses of the asphalt concrete represented by these samples are adequate for the amount and type of air traffic for these runways.

The field density results were determined from 4-in. cored specimens taken from each slab sample. The field density values were determined only for the surface course layer. The field density values for Runways $9 / 27$ and $14 / 32$ varied from 130.0 pcf to 136.8 pcf. The average field compaction results listed in Table 14 for these slab samples indicated that a majority of the in-place asphalt concrete did not meet the minimum compaction requirement of 97 percent. The field compaction results for the laboratory densities recompacted at $250^{\circ} \mathrm{F}$ varied from 93.4 to 98.1 percent. The field compaction results for the laboratory densities recompacted at $290^{\circ} \mathrm{F}$ were lower and varied from 92.8 to 97.3 percent.

The field compaction results and the visual voids on the cut faces of the slabs (Photos 6, 7, 12, 14, 16, 18, and 20) indicated that the in-place voids in the asphalt concrete mixtures were high. The in-place voids were calculated using field density values and two theoretical density values determined by MIL STD 620 B and ASTM D2041. The in-place void results are listed in Table 15. The in-place void results calculated using MIL STD 620B varied between 7.5 and 12.9 percent for Runway $9 / 27$ and between 10.8 and 11.2 percent for Runway 14/32. The in-place void results calculated using ASTM D2041 varied between 8.6 and 13.1 percent for Runway $9 / 27$ and between 9.0 and 9.6 for Runway 14/32. Asphalt concrete mixtures with in-place voids above 8 percent are considered permeable. Asphalt concrete mixtures that are permeable and allow water and air intrusion are subjected to oxidation which 
leads to weathering of the pavement surface. Excessive weathering of an asphalt concrete mixture decreases the durability and service life of a pavement.

Aggregate analysis. The results of the analyses performed on the aggregates recovered from the extraction process are listed in Tables 4 and 5 . The sieve analysis results have also been graphically shown in Figures 2-10. The aggregate gradations determined for the slab samples from Runway $9 / 27$ indicated that all samples have aggregate gradations that do not meet the contract specifications. The predominant problem with the aggregate gradations for the surface course mixtures is that the gradations were too coarse and not well graded. Slab samples $1 \mathrm{~A}, 3,4$, and 5 are extremely coarser than the specified limits. These slab samples also have an extremely open-textured surface (Photos 5, 11, 13, and 15). Slab samples 1B, 2, and 6 have aggregate gradations that exceed the upper limit on the No. 50 sieve and vary from the lower to upper limits of the specified limits. As a whole, the aggregate gradations determined from the slab samples taken from Runway 9/27 do not meet the required limits for heavy-duty airfield pavements.

The aggregate gradations determined from slab samples taken from Runway $14 / 32$ are inconsistent. Slab sample 7 had a gradation that did not meet the specifications and was similar to the coarse aggregate gradations found on Runway 9/27. Slab sample 8 had the only aggregate gradation that was close to meeting the required contract specifications.

The natural sand content of the slab samples was determined by visually observing the aggregate particles smaller than the No. 4 sieve under a microscope. The percentage of natural sand is calculated by determining the number of sand particles in the aggregate gradation. The natural sand contents in the aggregate gradations from Runway $9 / 27$ were all above the maximum limit of 15 percent. The natural sand content varied from 18.5 to 35.4 percent for slab samples 1-6. Slab samples 1 B, 2, and 6 had high natural sand contents of $23.2,35.4$, and 24.4 percent, respectively. These high natural sand contents are also shown in Figures 3, 4, and 8 by the "hump" at the No. 50 sieve. The natural sand content for slab samples 7 and 8 from Runway $14 / 32$ were 15.0 and 20.4 percent, respectively.

The LA abrasion test (ASTM C131) was conducted on combined samples of extracted aggregate. A combined sample from slab samples 1-3 was evaluated 
using Grading B. The percent wear of these aggregates was 37.0. A combined sample of slab samples 1-6 was used to evaluate Grading C. The percent wear of these aggregates was 34.9. The Florida limerock aggregate does meet the requirements of the specification.

Asphalt cement analysis. The test results for the asphalt cement recovered from the Abson recovery process are listed in Table 6 . The test results indicated that this material had aged and hardened during plant production and a two-year service life. The initial penetration for the Chevron AC-20 asphalt cement was 87. Typical values for the recovered penetration ranged between 19 and 30 . These values indicated a reduction in penetration of 66 to 78 percent. Asphalt cements recovered from mixtures after plant production typically have reduced penetration values of 40 to 50 percent. The ductility and viscosity values also indicated that the asphalt cement had hardened significantly.

In the previous visual inspection on 6 November, it was observed that an obvious color difference existed between the outside paving lanes and the inside lanes. Slab samples 2 and 5 were taken from the outside lanes. The ductility values indicated that there was a difference in the asphalt cements. The ductility values for slab samples 2 and 5 were 2 to 4 times greater than the other slab samples, indicating that this binder was not as brittle and hard as the asphalt cements of the inside lanes.

Recompaction analysis. The test results from the three recompaction studies are listed in Tables 7-12. All three recompaction procedures, ASTM D1559, MIL STD 620B (Method 100), and ASTM D3387, indicated that the asphalt concrete mixtures do not meet the contract specifications.

The asphalt contents determined from the extraction process were very low. The asphalt contents determined for slab samples from Runway $9 / 27$ ranged from 4.3 to 5.6 percent. The asphalt content for slab samples from Runway $14 / 32$ were 5.4 and 6.9 percent. The asphalt content recommended by the contractor as the optimum asphalt content was 6.5 percent. The asphalt contents of the in-place material were between 0.9 and 2.2 percent below the optimum asphalt content. Low asphalt contents cause improper film coating of aggregate particles which leads to insufficient bonding and raveling.

The voids total $\operatorname{mix}(\mathrm{VTM})$ requirement of 3 to 5 percent was not met by these asphalt concrete mixtures from Runway $9 / 27$. The VTM values were 
extremely high for all three recompaction procedures and each theoretical density determination, ASTM D2041 and MIL STD 620B (Method 101). The VTM values computed from the recompaction analysis using ASTM D1559 procedure ranged from 5.0 to 6.6 percent (ASTM D2041) and from 5.3 to 6.9 percent (MIL STD 620B).

The VTM values computed from the recompaction analysis using MIL STD 620B (Method 100) procedure ranged from 6.7 to 8.0 percent (ASTM D2041) and from 5.3 to 7.7 percent (MIL STD 620B). The VTM values computed from the gyratory analysis ranged from 6.2 to 8.6 percent (ASTM D2041) and from 5.6 to 7.0 percent (MIL STD 620B).

The other Marshall void property, voids filled with asphalt (VF), was also determined for these asphalt concrete mixtures from Runway 9/27. The VF values were extremely low for an asphalt concrete mixture that is used on a heavy-duty airfield pavement. Typical voids filled with asphalt requirement is 70 to 80 percent for airfield pavements. The VF values computed from the ASTM D1559 procedure ranged from 58.7 to 68.9 percent (ASTM D2041) and from 59.5 to 67.7 percent (MIL STD 620B). The VF values computed for the MIL STD 620B (Method 100) procedure ranged from 53.2 to 64.3 percent (ASTM D2041) and from 55.6 to 69.2 percent (MIL STD 620B). The VF values computed from the gyratory analysis ranged from 51.1 to 64.0 percent (ASTM D2041) and from 56.3 to 67.8 percent (MIL STD 620B).

The recompaction analysis of slab samples from Runway 14/32 indicated that these asphalt concrete mixtures did not fully meet the specification requirements but were much closer than the previously discussed slab samples. The asphalt content for slab sample 7 was 5.4 percent, while the asphalt content for slab 8 was 6.9 percent. The VTM values for slab 7 varied from 4.2 to 6.4 percent for the three recompaction procedures. The VTM values for slab 8 were much lower and varied from 2.3 to 4.5 percent for the recompaction procedures. The VF values for slab sample 7 were slightly lower than recommended values and varied from 64.3 to 76.3 percent. The VF values for slab sample 8 indicated that too much asphalt was in the mixture. The VF values ranged from 76.7 to 86.6 percent. The gyratory analysis also indicated that slab sample 8 had an excessive amount of asphalt cement in the mixture. A gyratory stability index (GSI) value of 1.1 indicated the asphalt concrete mixture had an excessive asphalt content. 
Effect of moisture. The results of laboratory tests to evaluate the effect of moisture on the asphalt concrete mixtures are listed in Tables 9, 10, and 13. The tests conducted on these asphalt concrete specimens indicated that moisture had little effect on the asphalt concrete mixtures. The retained stability values for the slab samples varied between 91.4 and 100 percent which is well above the minimum 75 percent requirement. The retained tensile strength values also indicated moisture had little effect on these asphalt concrete specimens. The retained tensile strength values ranged from 76.6 to 100 percent. 
The performance of the asphalt concrete overlays, especially Runway 9/27, has been unacceptable due to the raveling of the pavement surface. Based on the visual inspection of the runways and test results from the laboratory analysis, the poor performance of the asphalt concrete overlay was due to an improperly produced and constructed asphalt concrete mixture. Several factors that contributed to this improper asphalt mixture are listed below:

Field density. The field density and compaction results are low and did not meet the minimum compaction requirements. The high in-place voids total mix indicated the asphalt concrete mixtures were susceptible to weathering and decreased service life.

Aggregate gradation. The aggregate gradations were consistently out of specification and were predominantly coarse. Coarse gradations promote an open-textured pavement surface which allows increased raveling when combined with a low asphalt content.

Natural sand. The natural sand content was above the maximum 15 percent limit. The use of high percentages of local natural sand increased the incidence of roots, sticks, and organics in the asphalt concrete mixtures.

Asphalt cement. The test results for the recovered asphalt cements indicated that these materials have aged and hardened significantly during the two years these pavements have been in service. Hardened asphalt cements produce brittle asphalt concrete mixtures that increase the potential for weathering and raveling.

Asphalt content. The asphalt contents determined from the extraction process indicated the asphalt concrete mixtures had less asphalt cement than recommended by the JMF. The asphalt contents were extremely low, 1 to 2 percent by weight lower than the optimum asphalt content. These low asphalt contents are a major contributor to the raveling problem.

Recompaction analysis. The recompaction analyses for these slab samples indicated that the asphalt concrete mixtures did not meet the contract specifications. The Marshall mix design void properties were not acceptable for heavy-duty airfield pavements. The voids total mix values were extremely high, and the voids filled with asphalt values were consistently low. These 
Marshall properties indicate the in-place asphalt concrete does not have enough asphalt cement to properly coat the aggregate particles and to prevent further deterioration and raveling.

The combination of the factors listed above have contributed to pavement surface raveling that has occurred on Runways $9 / 27$ and $14 / 32$. The test results for the laboratory evaluation indicate that the in-place material is not the quality pavement required by the specification. Based on the test results of this investigation, the pavement surface raveling will continue and eventually cause a foreign object damage (FOD) problem. 


\section{PART V: RECOMMENDATIONS}

Based on the visual inspection and laboratory analysis of the in-place materials at Jacksonville Naval Air Station, the following recommendations are given:

a. The in-place asphalt concrete surface course material on Runway $9 / 27$ is unacceptable for airfield pavements and should be removed to eliminate surface raveling and potential foreign object damage (FOD).

b. The existing asphalt concrete surface course should be removed by cold milling to a minimum depth of 2 in.

c. An asphalt concrete layer 2 in. thick should be placed and constructed for the new runway surface. Proper materials and construction procedures should be required to ensure an acceptable pavement surface.

d. The existing asphalt concrete material on Runway $14 / 32$ is not exhibiting severe pavement raveling as is Runway 9/27. However, the potential exists for future deterioration to occur. Periodic inspections should be conducted by Jacksonville NAS personnel to monitor the pavement surface on Runway $14 / 32$ for further deterioration. 
Table 3

\section{$\underline{\text { Pavement Thickness and Field Density Results }}$}

\begin{tabular}{|c|c|c|c|c|}
\hline$\underline{\text { Slab }}$ & $\begin{array}{c}\text { Core } \\
\text { No. } \\
\end{array}$ & $\begin{array}{c}\text { Total Pavement } \\
\text { Thickness } \\
\text { (in.) }\end{array}$ & $\begin{array}{c}\text { Surface Course } \\
\text { Thickness } \\
\text { (in.) }\end{array}$ & $\begin{array}{l}\text { Field } \\
\text { Density } \\
\text { (pcf) }\end{array}$ \\
\hline \multirow[t]{4}{*}{1} & 1 & $47 / 8$ & $13 / 4$ & 137.3 \\
\hline & 2 & $43 / 4$ & $13 / 4$ & 135.8 \\
\hline & 3 & $43 / 4$ & $13 / 4$ & 136.3 \\
\hline & AVG & $43 / 4$ & $13 / 4$ & 136.5 \\
\hline \multirow[t]{4}{*}{2} & 1 & $51 / 4$ & $11 / 2$ & 131.6 \\
\hline & 2 & $53 / 4$ & $11 / 2$ & 131.1 \\
\hline & 3 & $51 / 2$ & $11 / 2$ & 129.8 \\
\hline & AVG & $51 / 2$ & $\overline{11 / 2}$ & $\overline{130.8}$ \\
\hline \multirow[t]{4}{*}{3} & 1 & $61 / 4$ & $15 / 8$ & 129.1 \\
\hline & 2 & $61 / 4$ & $11 / 2$ & 130.6 \\
\hline & 3 & $61 / 4$ & $11 / 2$ & 131.8 \\
\hline & AVG & $\overline{61 / 4}$ & $11 / 2$ & 130.5 \\
\hline \multirow[t]{4}{*}{4} & 1 & 8 & $11 / 2$ & 136.8 \\
\hline & 2 & $77 / 8$ & $13 / 8$ & 136.5 \\
\hline & 3 & $\underline{8}$ & $11 / 2$ & 137.2 \\
\hline & AVG & 8 & $\overline{11 / 2}$ & $\overline{136.8}$ \\
\hline \multirow[t]{4}{*}{5} & 1 & $61 / 4$ & $19 / 16$ & 135.0 \\
\hline & 2 & $63 / 8$ & $111 / 16$ & 134.9 \\
\hline & 3 & $61 / 2$ & $111 / 16$ & 133.8 \\
\hline & AVG & $63 / 8$ & $15 / 8$ & 134.6 \\
\hline \multirow[t]{4}{*}{6} & 1 & $63 / 8$ & $11 / 8$ & 129.7 \\
\hline & 2 & $61 / 4$ & $13 / 16$ & 130.8 \\
\hline & 3 & $63 / 8$ & $11 / 8$ & 129.6 \\
\hline & AVG & $63 / 8$ & $11 / 8$ & 130.0 \\
\hline \multirow[t]{4}{*}{7} & 1 & $63 / 8$ & $13 / 8$ & 131.9 \\
\hline & 2 & $63 / 4$ & $15 / 8$ & 133.4 \\
\hline & 3 & $61 / 2$ & $11 / 4$ & 131.7 \\
\hline & AVG & $61 / 2$ & $13 / 8$ & $\overline{132.3}$ \\
\hline \multirow[t]{4}{*}{8} & 1 & $53 / 4$ & $115 / 16$ & 131.5 \\
\hline & 2 & $53 / 4$ & $17 / 8$ & 131.8 \\
\hline & 3 & $53 / 4$ & $17 / 8$ & 131.4 \\
\hline & AVG & $53 / 4$ & $17 / 8$ & $\overline{131.6}$ \\
\hline
\end{tabular}


Table 4

\section{Surface Course Aggregate Analysis - Runway $9 / 27$}

Sieve JMF

Size JMF Tolerances Slab 1A Slab 1B Slab 2 Slab 3 Slab 4 Slab 5 Slab 6

$\begin{array}{lllllllll}3 / 4 & \text { in. } 100 & 100 & 100 & 100 & 100 & 100 & 100 & 100\end{array}$

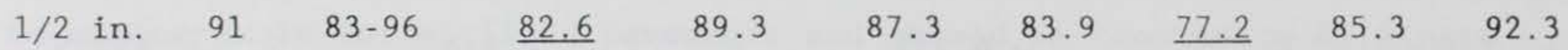

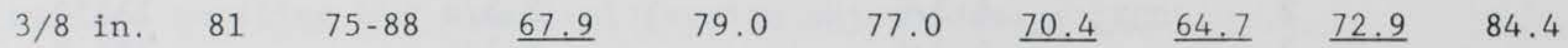

No. $4 \quad 64 \quad 59-71 \quad \underline{43.4} \quad \underline{55.3} \quad 62.0 \quad \underline{46.2} \quad \underline{43.2} \quad \underline{47.6} \quad 61.5$

No. $8 \quad 53 \quad 46-59 \quad \underline{35.0} \quad \underline{44.8} \quad 53.7 \quad \underline{36.5} \quad \underline{35.4} \quad \underline{38.8} \quad 48.3$

No. $16 \quad 40 \quad 34-46 \quad \underline{29.7} \quad 37.4 \quad 44.0 \quad \underline{31.2} \quad \underline{30.6} \quad \underline{32.6} \quad 39.5$

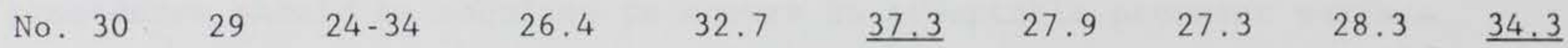

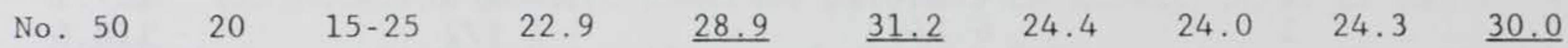

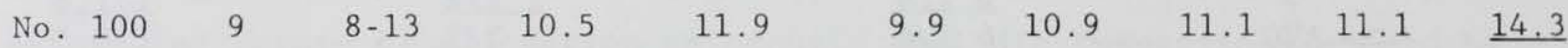

No. $\begin{array}{llllllllll}200 & 4 & 3-6 & 4.1 & 4.6 & 4.7 & 4.3 & 4.2 & 4.5 & 5.1\end{array}$

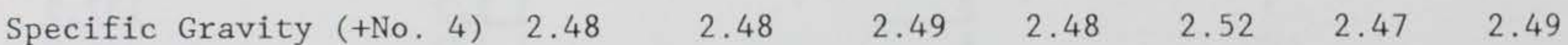

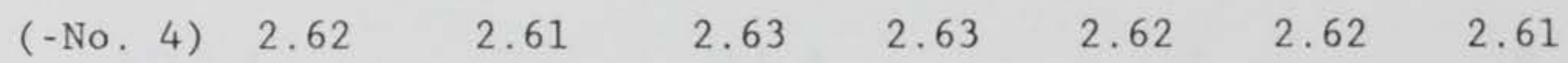

$\begin{array}{llllllll}\text { (Total) } & 2.54 & 2.55 & 2.56 & 2.55 & 2.56 & 2.54 & 2.56\end{array}$

Absorption

$(+$ No. 4) 1.9

2.0

2.4

2.0

2.6

2.3

2.0

$(-$ No. 4) 0.9

0.5

1.6

1.8

2.2

1.3

1.5

Fractured Faces

$\begin{array}{rrrrrrrr}(+ \text { No. 4) } & 100 & 100 & 96.2 & 99.3 & 99.6 & 99.4 & 100 \\ \text { (-No. 4) } & 100 & 100 & 100 & 100 & 100 & 99.5 & 99.5\end{array}$

Natural Sand Content

18.5

23.2

$35.4 \quad 20.2$

19.0

19.6

24.4

LA Abrasion

$\begin{array}{llllllll}\text { Grading B } & 37.0 & 37.0 & 37.0 & 37.0 & \ldots & \ldots & \ldots \\ \text { Grading C } & 34.9 & 34.9 & 34.9 & 34.9 & 34.9 & 34.9 & 34.9\end{array}$

NOTE: Underlined data are outside of JMF tolerances. 
Table 5

Surface Course Aggregate Analysis - Runway 14/32

\begin{tabular}{|c|c|c|c|c|}
\hline $\begin{array}{r}\text { Sieve } \\
\text { Size } \\
\end{array}$ & $\underline{\mathrm{JMF}}$ & $\begin{array}{c}\text { JMF } \\
\text { Tolerances } \\
\end{array}$ & $\underline{\mathrm{Slab} 7}$ & $\underline{\text { Slab } 8}$ \\
\hline $3 / 4$ in. & - - & - & 100 & 100 \\
\hline $1 / 2$ in. & 100 & 100 & $\underline{99.0}$ & $\underline{99.0}$ \\
\hline $3 / 8$ in. & 87 & $82-94$ & $\underline{81.9}$ & 90.1 \\
\hline No. 4 & 65 & $59-72$ & $\underline{51.8}$ & 65.7 \\
\hline No. 8 & 54 & $48-60$ & $\underline{40.3}$ & 49.0 \\
\hline No. 16 & 41 & $35-47$ & $\underline{31.9}$ & 38.3 \\
\hline No. 30 & 30 & $25-35$ & 25.9 & 31.2 \\
\hline No. 50 & 20 & $15-25$ & 20.2 & $\underline{25.1}$ \\
\hline No. 100 & 10 & $8-14$ & 10.9 & 13.3 \\
\hline No. 200 & 4.0 & $3-6$ & 5.2 & 5.3 \\
\hline Specific Gravity & $(+$ No. 4$)$ & & 2.52 & 2.54 \\
\hline & $(-$ No. 4$)$ & & 2.63 & 2.64 \\
\hline & (Total) & & 2.57 & 2.61 \\
\hline Absorption & (+No. 4) & & 2.9 & 2.7 \\
\hline & $(-$ No. 4$)$ & & 2.8 & 2.8 \\
\hline Fractured & $(+$ No. 4$)$ & & 100 & 99.7 \\
\hline & (-No. 4) & & 99.7 & 100 \\
\hline Natural Sand Con & t & & 15.0 & 20.4 \\
\hline
\end{tabular}

NOTE: Underlined data are outside of JMF tolerances. 
Table 6

Recovered Asphalt Cement Analysis

\begin{tabular}{|c|c|c|c|c|c|}
\hline$\underline{\mathrm{S} l a b}$ & $\begin{array}{c}\text { Penetration } \\
(0.1 \mathrm{~mm})\end{array}$ & $\begin{array}{r}\text { Absolute } \\
\text { Viscosity } \\
\text { (poises) } \\
\end{array}$ & $\begin{array}{c}\text { Kinematic } \\
\text { Viscosity } \\
(c S t) \\
\end{array}$ & $\begin{array}{l}\text { Specific } \\
\text { Gravity }\end{array}$ & $\begin{array}{l}\text { Ductility } \\
(\mathrm{cm})\end{array}$ \\
\hline $1 \mathrm{~A}$ & 24 & 45,085 & 1540 & 1.064 & 10 \\
\hline $1 \mathrm{~B}$ & 22 & 36,698 & 1355 & 1.057 & 8 \\
\hline 2 & 30 & 17,063 & 1101 & 1.050 & 42 \\
\hline 3 & 25 & 27,526 & 1194 & 1.060 & 9 \\
\hline 4 & 26 & 27,744 & 1134 & 1.059 & 10 \\
\hline 5 & 26 & 28,657 & 1451 & 1.056 & 22 \\
\hline 6 & 19 & 57,796 & 1614 & 1.060 & 7 \\
\hline 7 & 24 & 21,109 & 1530 & 1.048 & 40 \\
\hline 8 & 27 & 26,164 & 1531 & 1.054 & 32 \\
\hline
\end{tabular}


Table 7

Surface Course Mixture Recompaction Analysis - Runway 9/27

$\underline{290^{\circ} \mathrm{F} \text { Compaction Temperature }-75 \text { Blow Hand Hammer }}$

\begin{tabular}{|c|c|c|c|c|c|c|}
\hline Property & $\begin{array}{l}\text { Specs } \\
\text { (JMF) } \\
\end{array}$ & $\underline{\text { S1ab } 2}$ & $\underline{\mathrm{Slab} 3}$ & $\underline{\text { Slab } 4}$ & $\underline{\text { Slab } 5}$ & $\underline{\mathrm{S} 1 \mathrm{ab} 6}$ \\
\hline Asphalt Content $(q)$ & 6.5 & 5.5 & 4.3 & 5.3 & 4.6 & 5.2 \\
\hline $\begin{array}{l}\text { Recompacted Density } \\
(\operatorname{pcf})\end{array}$ & 135.9 & 138.6 & 140.6 & 140.6 & 140.1 & 141.1 \\
\hline $\begin{array}{l}\text { Theoretical Density } \\
\text { (pcf) }\end{array}$ & 141.3 & & & & & \\
\hline MIL STD $620 B$ & & 148.8 & 149.9 & 148.7 & 148.8 & 148.9 \\
\hline ASTM D2041 & & 148.4 & 150.1 & 149.8 & 149.9 & 148.5 \\
\hline Stability (1bs) & $1800 \mathrm{~min}$ & 3846 & 5246 & 5119 & 5392 & 6119 \\
\hline Flow (0.01 in.) & $8-16$ & 8 & 9 & 9 & 7 & 7 \\
\hline Voids Total Mix ( & $3-5$ & & & & & \\
\hline Mil STD $620 B$ & $(3.8)$ & 6.9 & 6.2 & 5.5 & 5.9 & 5.3 \\
\hline ASTM D2041 & & 6.6 & 6.4 & 6.2 & 6.5 & 5.0 \\
\hline Voids Filled ( 8$)$ & - & & & & & \\
\hline Mil STD $620 B$ & & 62.7 & 59.5 & 67.3 & 62.4 & 67.7 \\
\hline ASTM D2041 & & 63.7 & 58.7 & 64.6 & 60.1 & 68.9 \\
\hline Voids in Mineral & & & & & & \\
\hline $\begin{array}{l}\text { Aggregate }\left(\frac{8}{8}\right) \\
\text { Mil STD } 620 \mathrm{~B}\end{array}$ & 15 min & & 153 & 168 & 15.7 & 16.4 \\
\hline $\begin{array}{l}\text { Mil STD 620B } \\
\text { ASTM D2041 }\end{array}$ & $(16.2)$ & $\begin{array}{l}18.5 \\
18.2\end{array}$ & 15.5 & 17.5 & 16.3 & 16.1 \\
\hline
\end{tabular}


Table 8

Surface Course Mixture Recompaction Analysis - Runway 14/32

$\underline{290^{\circ} \mathrm{F} \text { Compaction Temperature- } 75 \text { Blow Hand Hammer }}$

\begin{tabular}{|c|c|c|c|}
\hline Property & $\begin{array}{l}\text { Specs } \\
\text { (JMF) } \\
\end{array}$ & $\underline{\mathrm{Slab} 7}$ & $\underline{\text { Slab } 8}$ \\
\hline Asphalt Content ( $\left(\frac{8}{)}\right.$ & 6.5 & 5.4 & 6.9 \\
\hline $\begin{array}{l}\text { Recompacted Density } \\
(\mathrm{pcf})\end{array}$ & 135.0 & 141.0 & 141.3 \\
\hline $\begin{array}{l}\text { Theoretical Density } \\
\text { (pcf) }\end{array}$ & 140.7 & & \\
\hline MIL STD $620 B$ & & 149.0 & 147.6 \\
\hline ASTM D2041 & & 146.3 & 144.6 \\
\hline Stability (lbs) & $1800 \mathrm{~min}$ & $6000+$ & 5275 \\
\hline Flow (0.01 in.) & $8-16$ & 8 & 8 \\
\hline Voids Total Mix ( $(8)$ & $3-5$ & & \\
\hline MIL STD $620 B$ & $(4.0)$ & 5.3 & 4.2 \\
\hline ASTM D2041 & & 5.0 & 2.3 \\
\hline Voids Filled ( $(z)$ & - & & \\
\hline MIL STD $620 B$ & & 68.6 & 77.9 \\
\hline ASTM D2041 & & 76.3 & 86.6 \\
\hline Voids in Mineral & & & \\
\hline Aggregate $(8)$ & $16 \mathrm{~min}$ & & \\
\hline MIL STD $620 B$ & $(15.6)$ & 16.9 & 19.0 \\
\hline ASTM D2041 & & 15.2 & 17.1 \\
\hline
\end{tabular}


Table 9

\section{Surface Course Mixture Recompaction Analysis - Runway $9 / 27$}

$250^{\circ} \mathrm{F}$ Compaction Temperature -75 B1ow Hand Hammer

\begin{tabular}{|c|c|c|c|c|c|c|c|c|}
\hline Property & $\begin{array}{l}\text { Specs } \\
\text { (JMF) }\end{array}$ & $\underline{\text { Slab } 1 \mathrm{~A}}$ & $\underline{\text { Slab 1B }}$ & $\underline{\text { Slab } 2}$ & $\underline{\text { Slab } 3}$ & $\underline{\text { Slab } 4}$ & $\underline{\text { Slab } 5}$ & $\underline{\text { Slab } 6}$ \\
\hline Asphalt Content ( $(8)$ & 6.5 & 4.3 & 5.6 & 5.5 & 4.3 & 5.3 & 4.6 & 5.2 \\
\hline $\begin{array}{l}\text { Recompacted Density } \\
(\operatorname{pcf})\end{array}$ & 135.9 & 140.0 & 139.6 & 137.4 & 139.2 & 139.5 & 138.5 & 138.6 \\
\hline $\begin{array}{l}\text { Theoretical Density } \\
\text { (pcf) }\end{array}$ & 141.3 & & & & & & & \\
\hline MIL STD $620 B$ & & 149.5 & 147.5 & 148.8 & 149.9 & 148.7 & 148.8 & 148.9 \\
\hline ASTM D2041 & & 152.2 & 149.4 & 148.4 & 150.1 & 149.8 & 149.9 & 148.5 \\
\hline Stability (1bs) & $1800 \mathrm{~min}$ & 5731 & 5029 & 3578 & 4992 & 4520 & 4725 & 5046 \\
\hline Flow (0.01 in.) & $8-16$ & 9 & 9 & 9 & 7 & 8 & 14 & 8 \\
\hline Voids Total Mix ( & $3-5$ & & & & & & & \\
\hline $\begin{array}{l}\text { MIL STD } 620 B \\
\text { ASTM D2041 }\end{array}$ & $(3.8)$ & $\begin{array}{l}6.3 \\
8.0\end{array}$ & $\begin{array}{l}5.3 \\
6.6\end{array}$ & $\begin{array}{l}7.7 \\
7.4\end{array}$ & $\begin{array}{l}7.2 \\
7.3\end{array}$ & $\begin{array}{l}6.2 \\
6.9\end{array}$ & $\begin{array}{l}7.0 \\
7.6\end{array}$ & $\begin{array}{l}7.0 \\
6.7\end{array}$ \\
\hline Voids Filled ( 8 ) & $\cdots$ & & & & & & & \\
\hline MIL STD 620B & & 59.1 & 69.2 & 59.9 & 55.6 & 64.4 & 58.1 & 60.9 \\
\hline ASTM D2041 & & 53.2 & 64.3 & 60.9 & 55.2 & 61.9 & 56.1 & 61.9 \\
\hline Voids in Mineral & & & & & & & & \\
\hline $\begin{array}{l}\text { Aggregate }\left(\frac{8}{8}\right) \\
\text { MIL STD } 620 \mathrm{~B}\end{array}$ & $\begin{array}{l}15 \mathrm{~min} \\
(16.2)\end{array}$ & 15.4 & 17.2 & 19.2 & 16.2 & 17.4 & 16.7 & 17.9 \\
\hline ASTM D2041 & & 17.1 & 18.5 & 18.9 & 16.3 & 18.1 & 17.3 & 17.6 \\
\hline Retained Stability $(8)$ & $75 \min$ & - & -- & 100.0 & 97.0 & 100.0 & 97.1 & 97.1 \\
\hline
\end{tabular}


Table 10

Surface Course Mixture Recompaction Analysis - Runway 14/32

$\underline{250^{\circ} \mathrm{F} \text { Compaction Temperature }-75 \text { Blow Hand Hammer }}$

\begin{tabular}{|c|c|c|c|}
\hline Property & $\begin{array}{l}\text { Specs } \\
\text { (JMF) }\end{array}$ & $\underline{\mathrm{S} l \mathrm{ab} 7}$ & $\underline{\mathrm{S} 1 \mathrm{ab} 8}$ \\
\hline Asphalt Content ( $(8)$ & 6.5 & 5.4 & 6.9 \\
\hline $\begin{array}{l}\text { Recompacted Density } \\
\text { (pcf) }\end{array}$ & 135.0 & 139.4 & 140.9 \\
\hline $\begin{array}{l}\text { Theoretical Density } \\
\text { (pcf) }\end{array}$ & 140.7 & & \\
\hline MIL STD 620B & & 149.0 & 147.6 \\
\hline ASTM D2041 & & 146.3 & 144.6 \\
\hline Stability (1bs) & $1800 \mathrm{~min}$ & 5354 & 4875 \\
\hline Flow (0.01 in.) & $8-16$ & 9 & 9 \\
\hline Voids Total Mix ( () & $3-5$ & & \\
\hline MIL STD 620B & $(4.0)$ & 6.4 & 4.5 \\
\hline ASTM D2041 & & 4.7 & 2.6 \\
\hline Voids Filled ( $(8)$ & $\cdots$ & & \\
\hline MIL STD $620 B$ & & 64.3 & 76.7 \\
\hline ASTM D2041 & & 71.0 & 85.1 \\
\hline Voids in Mineral & & & \\
\hline Aggregate $(z)$ & $16 \min$ & & \\
\hline MIL STD $620 \mathrm{~B}$ & $(15.6)$ & 17.9 & 19.3 \\
\hline ASTM D2041 & & 16.2 & 17.4 \\
\hline Retained Stability ( $(\&)$ & $75 \min$ & 91.4 & 100.0 \\
\hline
\end{tabular}


Table 11

Gyratory Analysis of Surface Course Mixture - Runway 9/27

Property

Asphalt Content ( 8 )

Recompacted Density

(pcf)

Theoretical Density (pcf)

MIL STD 620B

ASTM D2041

Stability (1bs)

Flow (0.01 in.)

Voids Total Mix ( 8 )

MIL STD 620B

ASTM D2041

Voids Filled ( 8 )

MIL STD 620B

ASTM D2041

Voids in Mineral

Aggregate ( 8 )

MIL STD 620B

ASTM D2041

Gyratory Stability

Index (GSI)

\section{$\underline{\text { Slab 1A Sla }}$}

$\begin{array}{lll}4.3 & 5.6 & 5.5\end{array}$

$\underline{\text { Slab } 3}$

$\underline{\text { Slab } 4} \underline{\text { Slab } 5}$ Slab 6

$\begin{array}{lllllll}139.1 & 139.2 & 138.6 & 139.4 & 140.2 & 138.9 & 139.3\end{array}$

$\begin{array}{lllllll}149.5 & 147.5 & 148.8 & 149.9 & 148.7 & 148.8 & 148.9\end{array}$ $\begin{array}{lllllll}152.2 & 149.4 & 148.4 & 150.1 & 149.8 & 149.9 & 148.5\end{array}$

$\begin{array}{lllllll}5252 & 4753 & 4059 & 4888 & 4706 & 5047 & 5228\end{array}$

$\begin{array}{lllllll}10 & 11 & 11 & 10 & 9 & 12 & 7\end{array}$

$\begin{array}{lllllll}7.0 & 5.6 & 6.9 & 7.0 & 5.7 & 6.7 & 6.5 \\ 8.6 & 6.8 & 6.6 & 7.1 & 6.4 & 7.3 & 6.2\end{array}$

$\begin{array}{lllllll}56.3 & 67.8 & 62.7 & 56.5 & 66.3 & 59.2 & 62.9\end{array}$

$\begin{array}{lllllll}51.1 & 63.4 & 63.7 & 56.2 & 63.6 & 57.1 & 64.0\end{array}$

$\begin{array}{lllllll}16.0 & 17.4 & 18.5 & 16.1 & 16.9 & 16.4 & 17.5\end{array}$

$\begin{array}{lllllll}17.6 & 18.6 & 18.2 & 16.2 & 17.6 & 17.0 & 17.2\end{array}$

$\begin{array}{lllllll}0.92 & 0.94 & 0.93 & 0.96 & 0.99 & 0.93 & 0.95\end{array}$ 
Gyratory Analysis of Surface Course Mixture - Runway 14/32

\section{Property}

Asphalt Content ( 8$)$

Recompacted Density (pcf)

Theoretical Density (pcf)

MIL STD 620B

ASTM D2041

Stability (1bs)

Flow (0.01 in.)

Voids Total Mix (

MIL STD $620 B$

ASTM D2041

Voids Filled ( 8$)$

MIL STD 620B

ASTM D2041

Voids in Mineral Aggregate ( 8 )

MIL STD 620B

ASTM D2041

Gyratory Stability Index (GSI)
$\underline{\mathrm{Slab} 7}$

5.4

6.9

140.1

141.3

149.0

147.6

146.3

144.6

5334

4992

12

9

5.9

4. 2

4. 2

2. 3

66.3

77.9

73.4

86.6

17.5

19.0

15.8

17.1

0.96

1.1 
Table 13

Effect of Moisture on Surface Course Mixture

\begin{tabular}{cccc}
$\underline{\text { Slab }}$ & $\begin{array}{c}\text { Tensile } \\
\text { Strength } \\
\text { (psi) }\end{array}$ & $\begin{array}{c}\text { Soaked } \\
\text { Tensile } \\
\text { Strength } \\
\text { (psi) }\end{array}$ & $\begin{array}{c}\text { Retained } \\
\text { Tensile } \\
\text { Strength } \\
\text { (psi) }\end{array}$ \\
3 & 206.0 & 196.5 & 95.4 \\
4 & 248.2 & 206.5 & 83.2 \\
5 & 212.7 & 201.8 & 94.9 \\
6 & 258.9 & 198.3 & 76.6 \\
7 & 239.4 & 229.5 & 95.9 \\
8 & 146.2 & 149.0 & 100 \\
\hline 198.4 & 191.4 & 96.5
\end{tabular}


Table 14

Field Compaction Results

\begin{tabular}{|c|c|c|c|c|c|}
\hline Slab & $\begin{array}{c}\text { Field } \\
\text { Density } \\
\text { (pcf) } \\
\end{array}$ & $\begin{array}{c}\text { Recompacted } \\
\text { Laboratory } \\
\text { Density } \\
\left(250^{\circ} \mathrm{F}\right) * \\
\end{array}$ & $\begin{array}{c}\text { Percent } \\
\text { Compaction }\end{array}$ & $\begin{array}{l}\text { Recompacted } \\
\text { Laboratory } \\
\text { Density } \\
\left(290^{\circ} \mathrm{F}\right) * * \\
\end{array}$ & $\begin{array}{c}\text { Percent } \\
\text { Compaction }\end{array}$ \\
\hline 1 & 136.5 & 139.8 & 97.6 & $\ldots$ & - \\
\hline 2 & 130.8 & 137.4 & 95.2 & 138.6 & 94.4 \\
\hline 3 & 130.5 & 139.2 & 93.8 & 140.6 & 92.8 \\
\hline 4 & 136.8 & 139.5 & 98.1 & 140.6 & 97.3 \\
\hline 5 & 134.6 & 138.5 & 97.2 & 140.1 & 96.1 \\
\hline 6 & 130.0 & 138.6 & 93.8 & 141.1 & 92.1 \\
\hline 7 & 132.3 & 139.4 & 94.9 & 141.0 & 93.8 \\
\hline 8 & 131.6 & 140.9 & 93.4 & 141.3 & 93.1 \\
\hline
\end{tabular}

* 75 blow hand hammer, MIL STD 620B, Method 100

** 75 blow hand hammer, ASTM D1559 
Table 15

\section{In place Void Results}

\begin{tabular}{|c|c|c|c|c|c|}
\hline$\underline{\text { Slab }}$ & $\begin{array}{c}\text { Field } \\
\text { Density } \\
(p c f)\end{array}$ & $\begin{array}{c}\text { MIL STD 620B } \\
\text { Theoretical } \\
\text { Density } \\
\text { (pcf) } \\
\end{array}$ & $\begin{array}{c}\text { In-place } \\
\text { Voids } \\
(8) \\
\end{array}$ & $\begin{array}{l}\text { ASTM D2041 } \\
\text { Theoretical } \\
\text { Density } \\
\text { (pcf) }\end{array}$ & $\begin{array}{c}\text { In-place } \\
\text { Voids } \\
(8)\end{array}$ \\
\hline $1 \mathrm{~A}$ & 136.5 & 149.5 & 8.7 & 152.2 & 10.3 \\
\hline $1 B$ & 136.5 & 147.5 & 7.5 & 149.4 & 8.6 \\
\hline 2 & 130.8 & 148.8 & 12.1 & 148.4 & 11.6 \\
\hline 3 & 130.5 & 149.9 & 12.9 & 150.1 & 13.1 \\
\hline 4 & 136.8 & 148.7 & 8.0 & 149.8 & 8.7 \\
\hline 5 & 134.6 & 148.8 & 9.5 & 149.9 & 10.2 \\
\hline 6 & 130.0 & 148.9 & 12.7 & 148.5 & 12.5 \\
\hline 7 & 132.3 & 149.0 & 11.2 & 146.3 & 9.6 \\
\hline 8 & 131.6 & 147.6 & 10.8 & 144.6 & 9.0 \\
\hline
\end{tabular}


$\overline{6}$
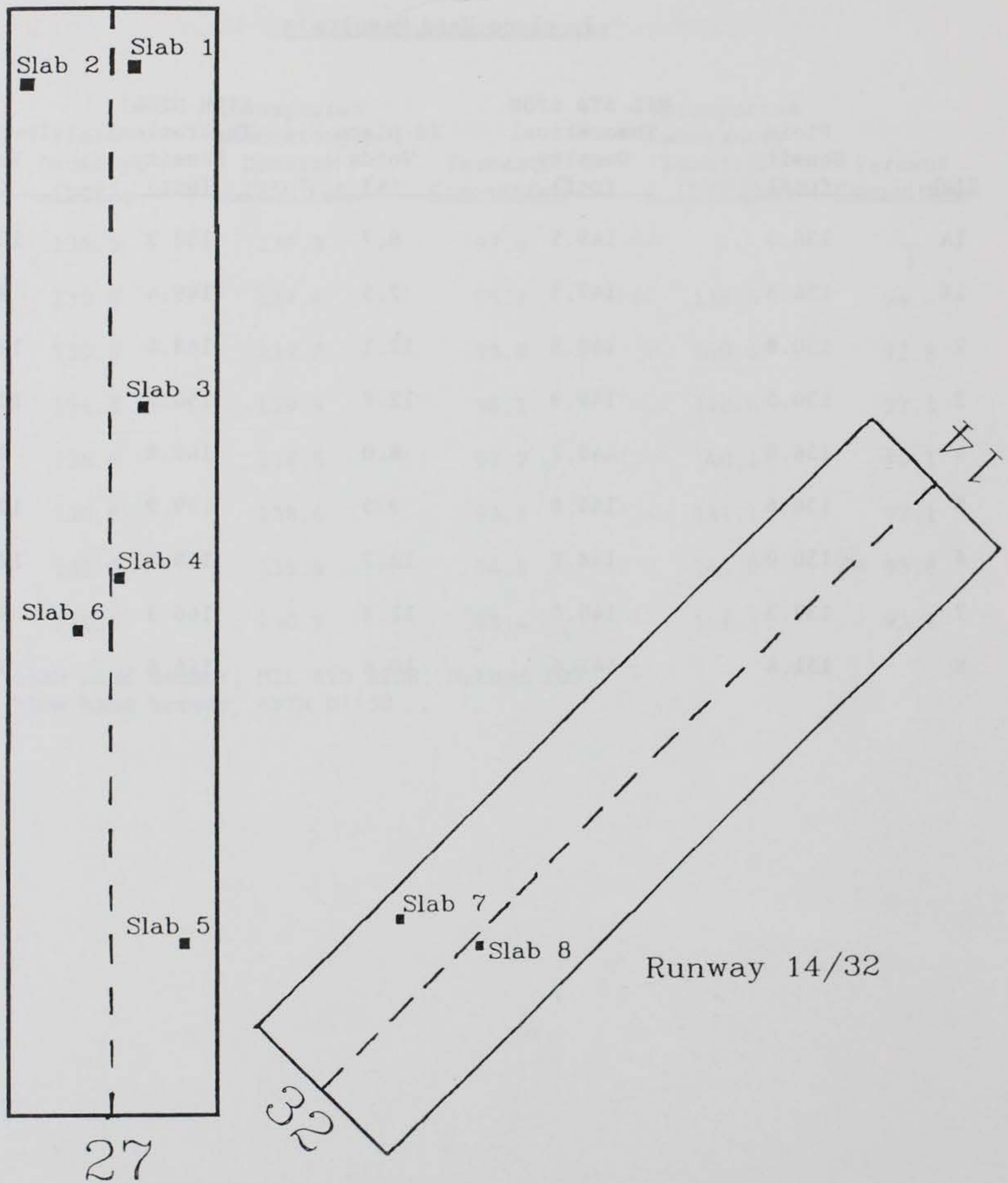

Runway $9 / 27$

Figure 1. Layout of slab sample locations for Runway $9 / 27$ and $14 / 32$ (Not to scale) 


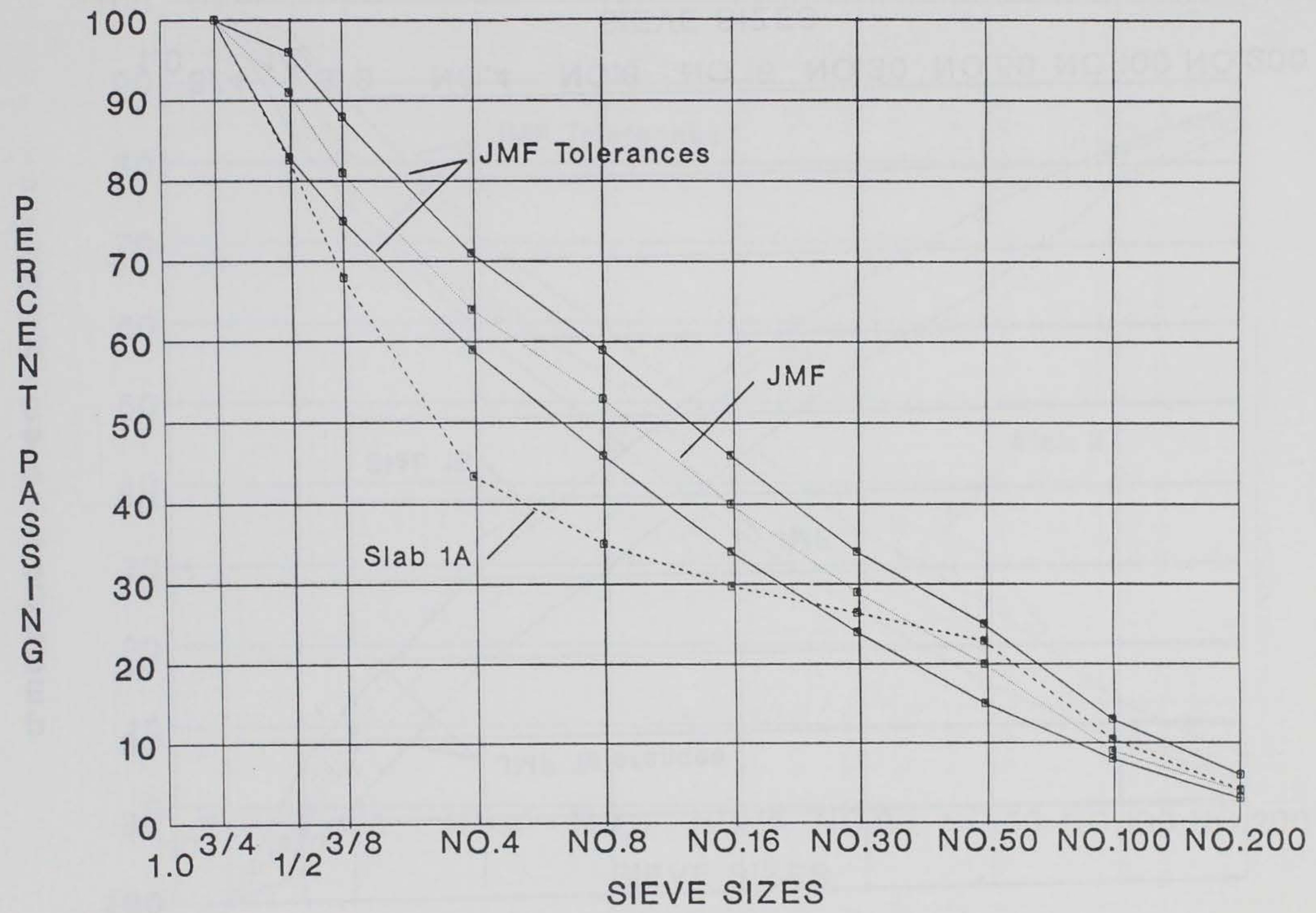

Figure 2. Aggregate gradation - Slab 1-A 


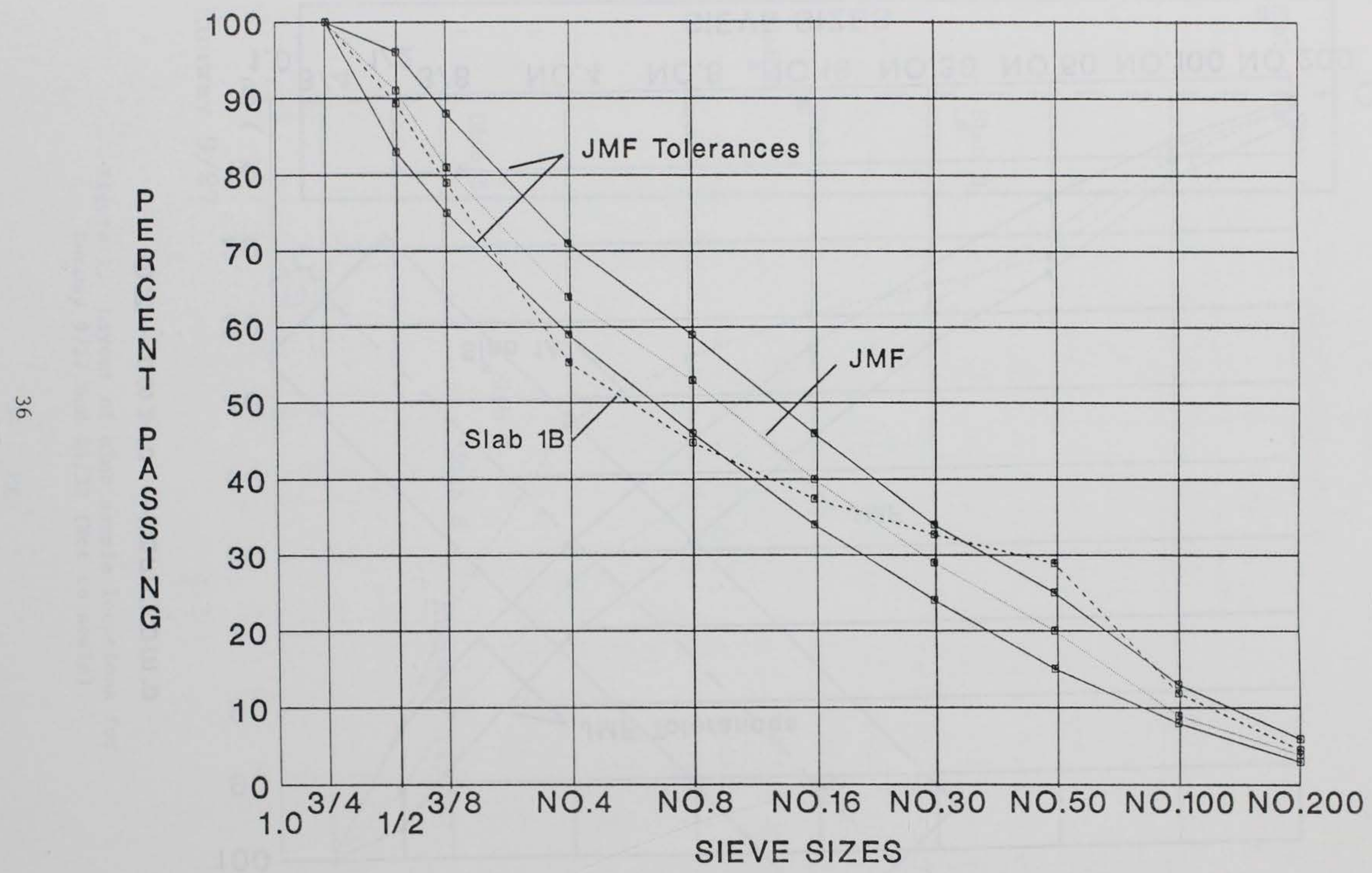

Figure 3. Aggregate gradation - Slab 1-B 


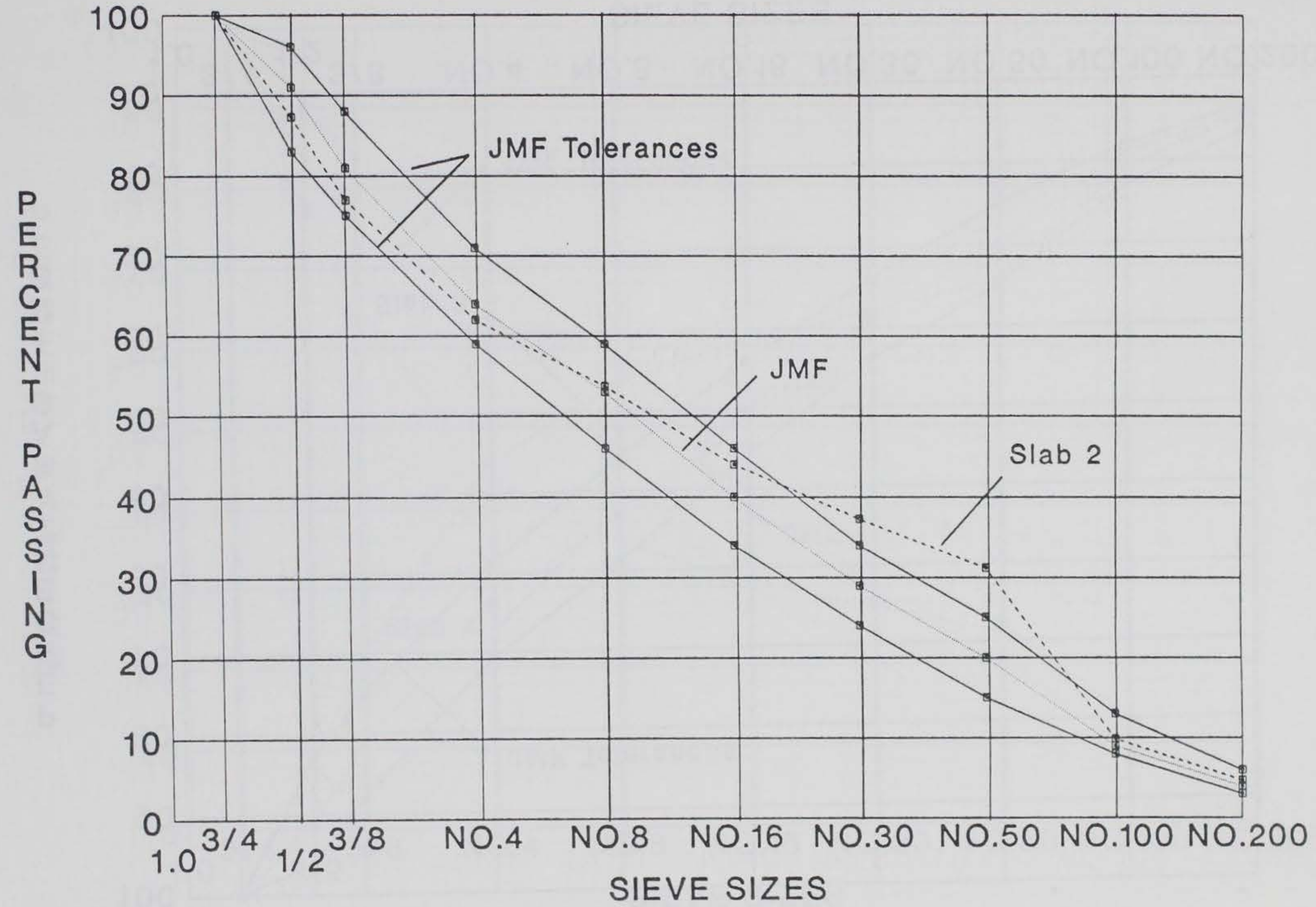

Figure 4. Aggregate gradation - Slab 2 


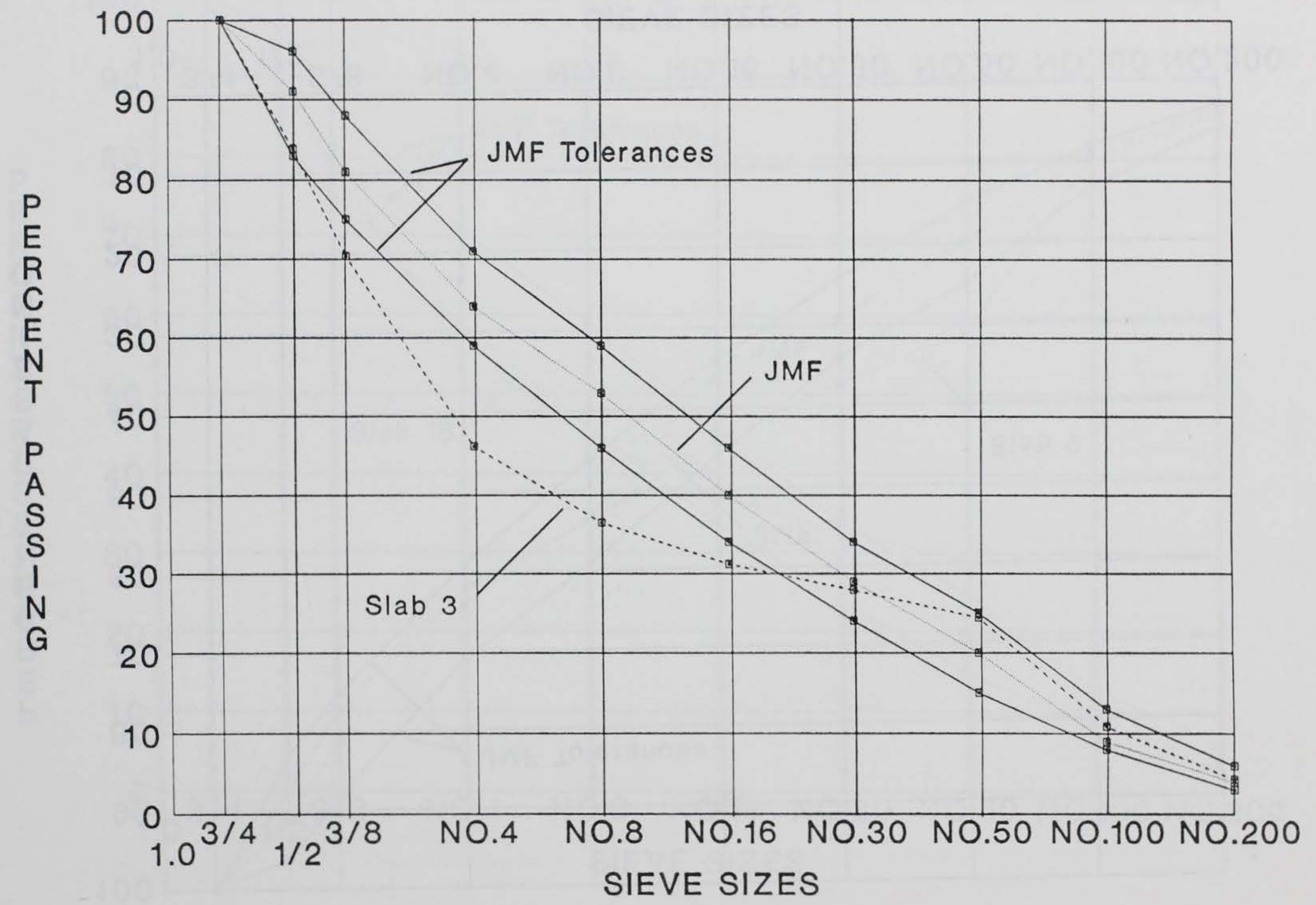

Figure 5. Aggregate gradation - Slab 3 


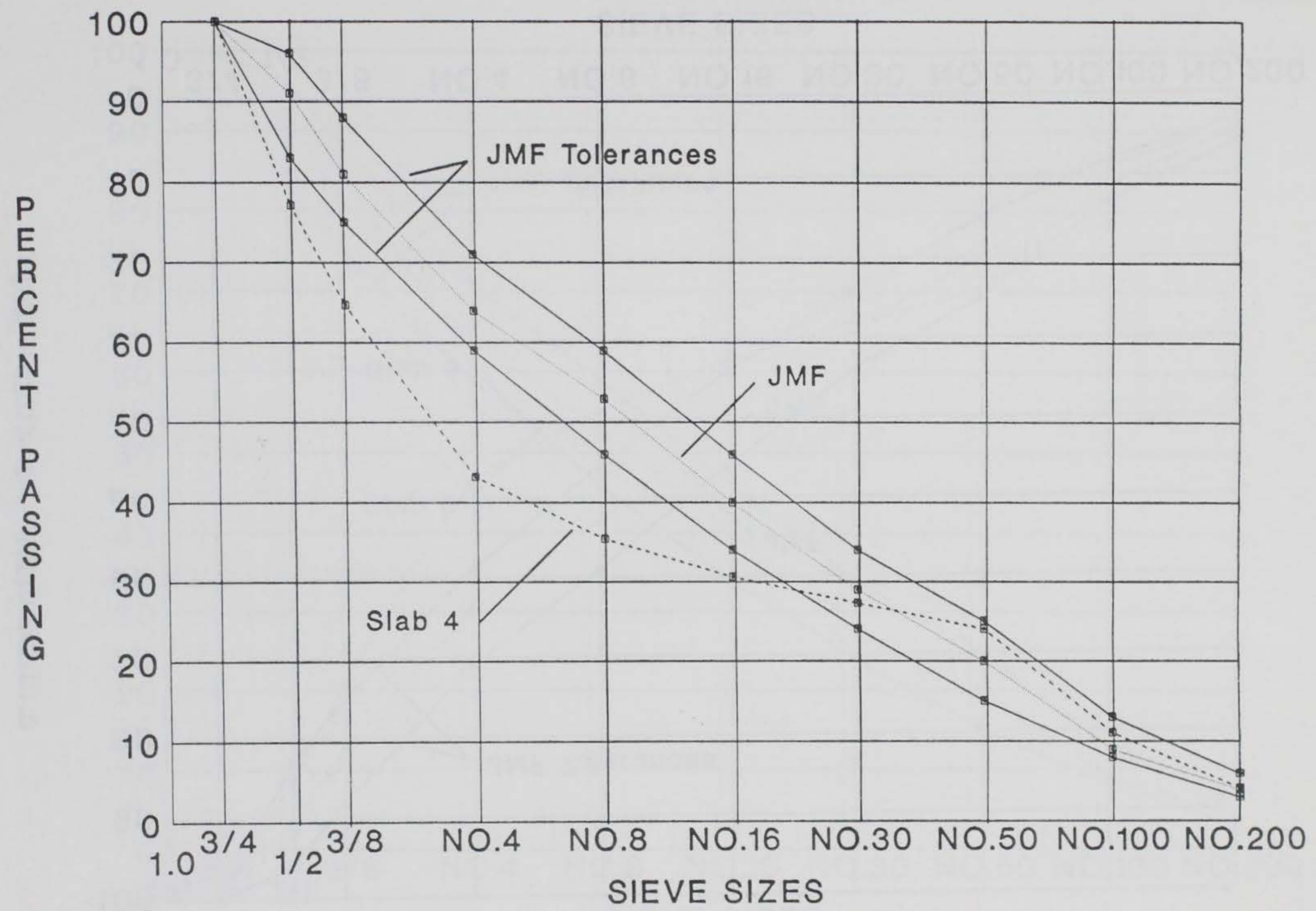

Figure 6. Aggregate gradation - Slab 4 


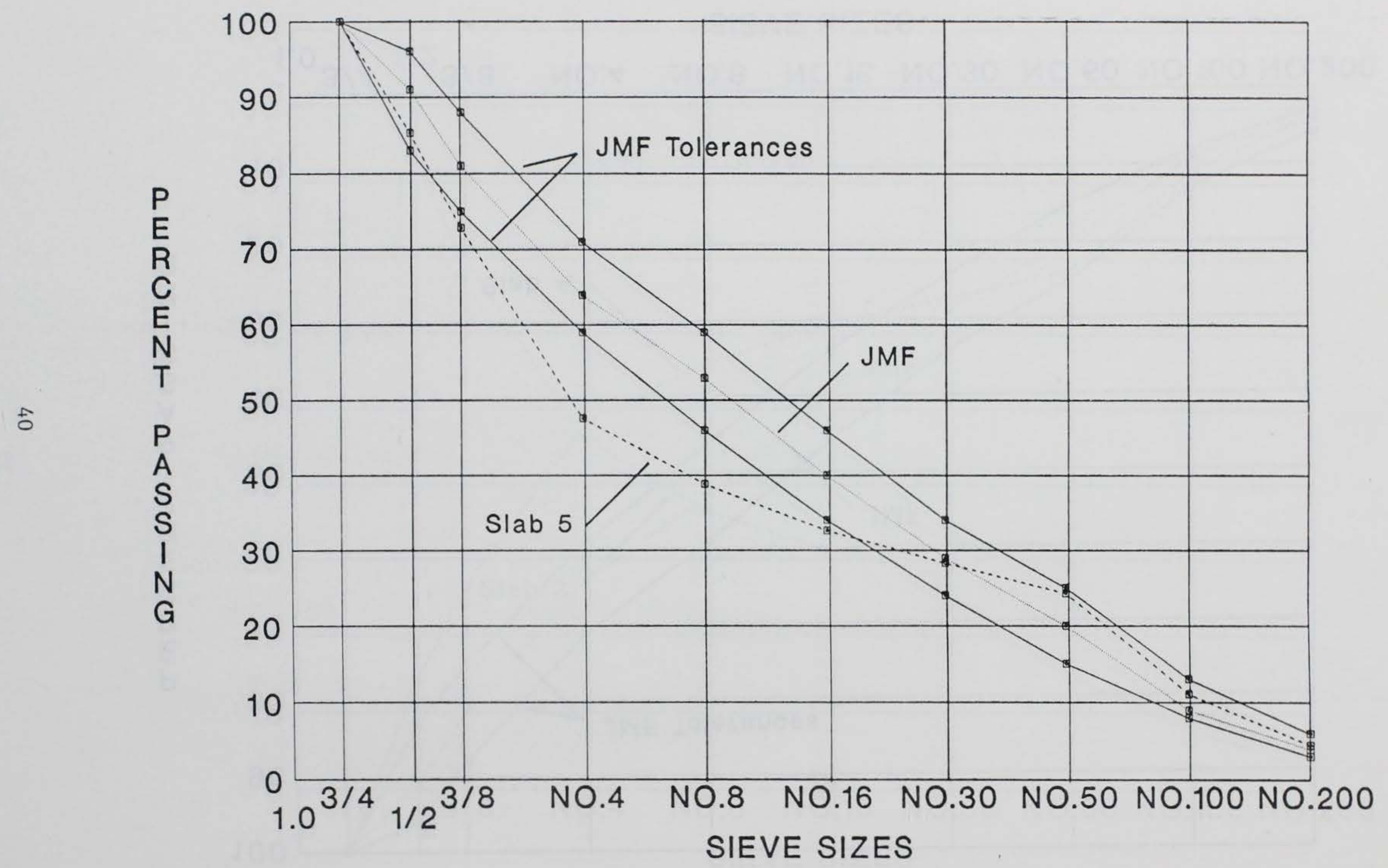

Figure 7. Aggregate gradation - Slab 5 


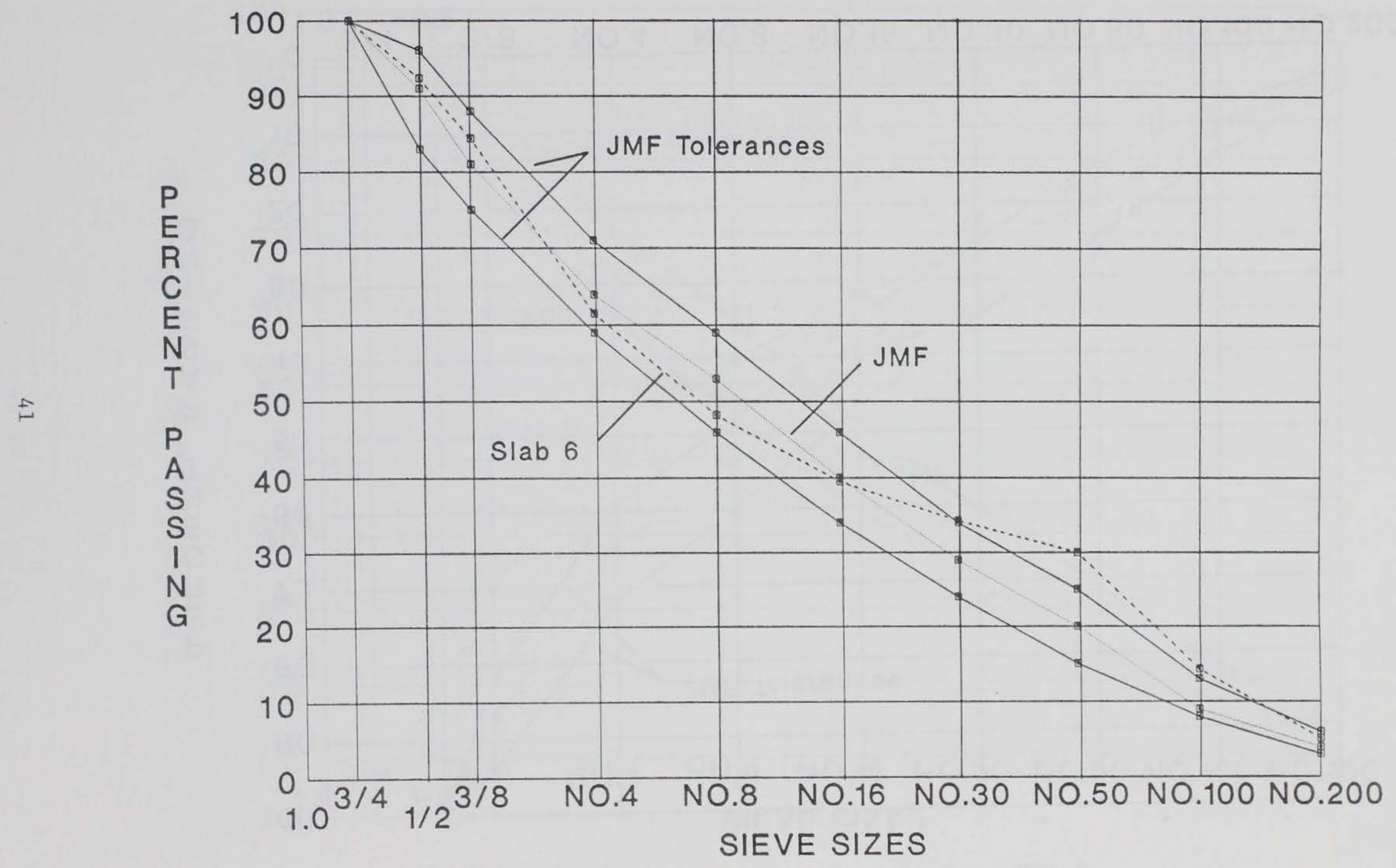

Figure 8. Aggregate gradation - S1ab 6 


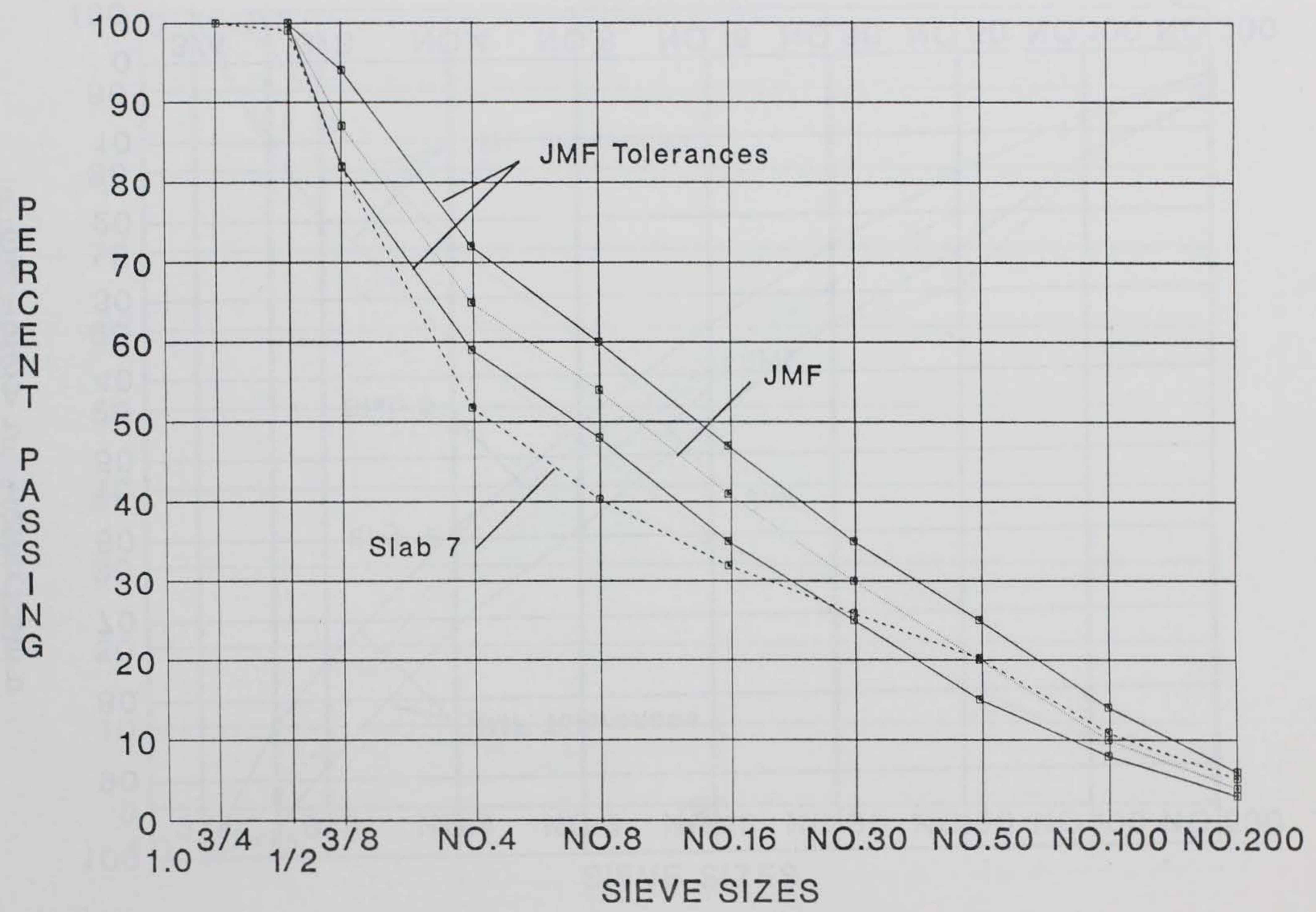

Figure 9. Aggregate gradation - Slab 7 


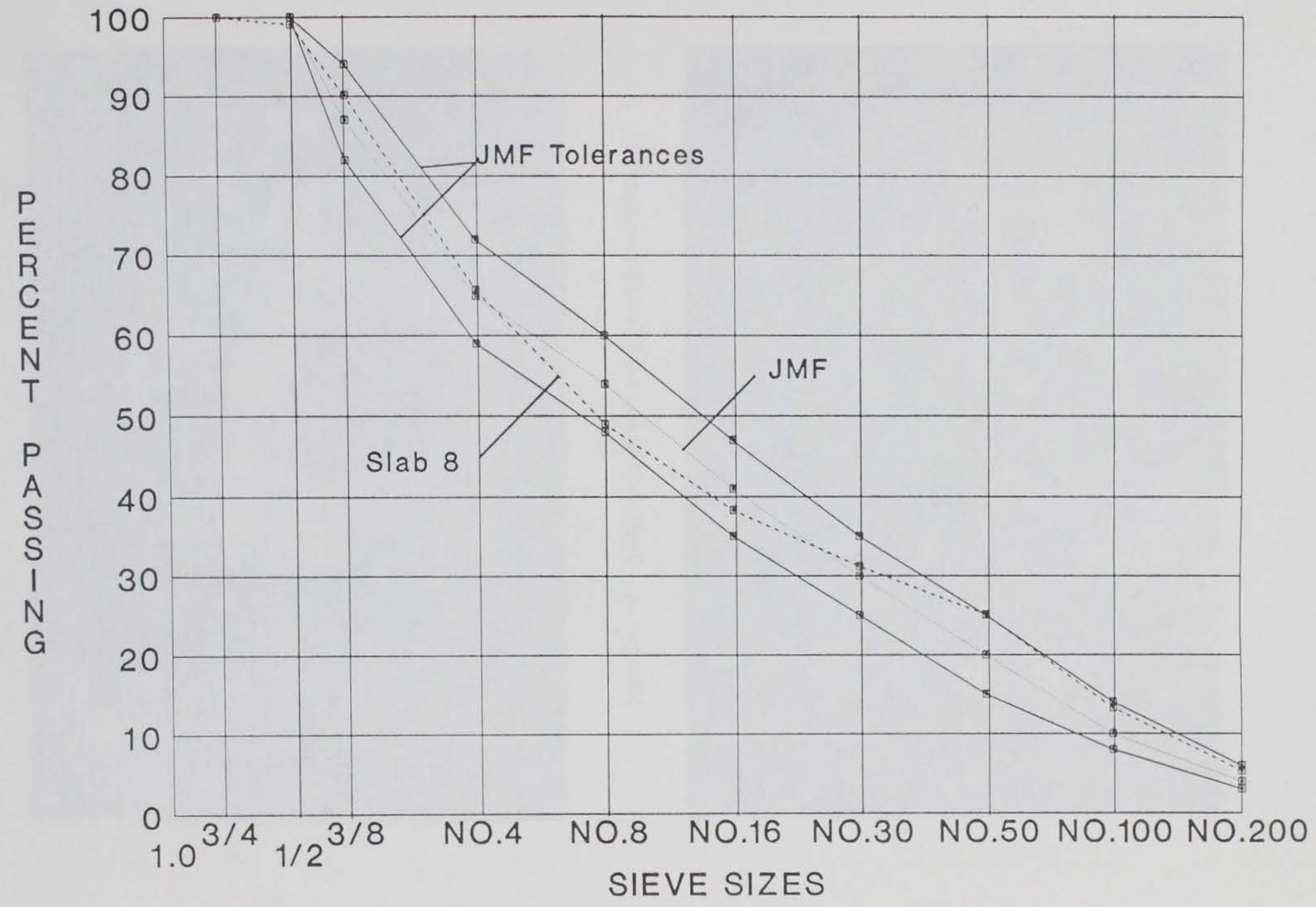

Figure 10. Aggregate gradation - Slab 8 


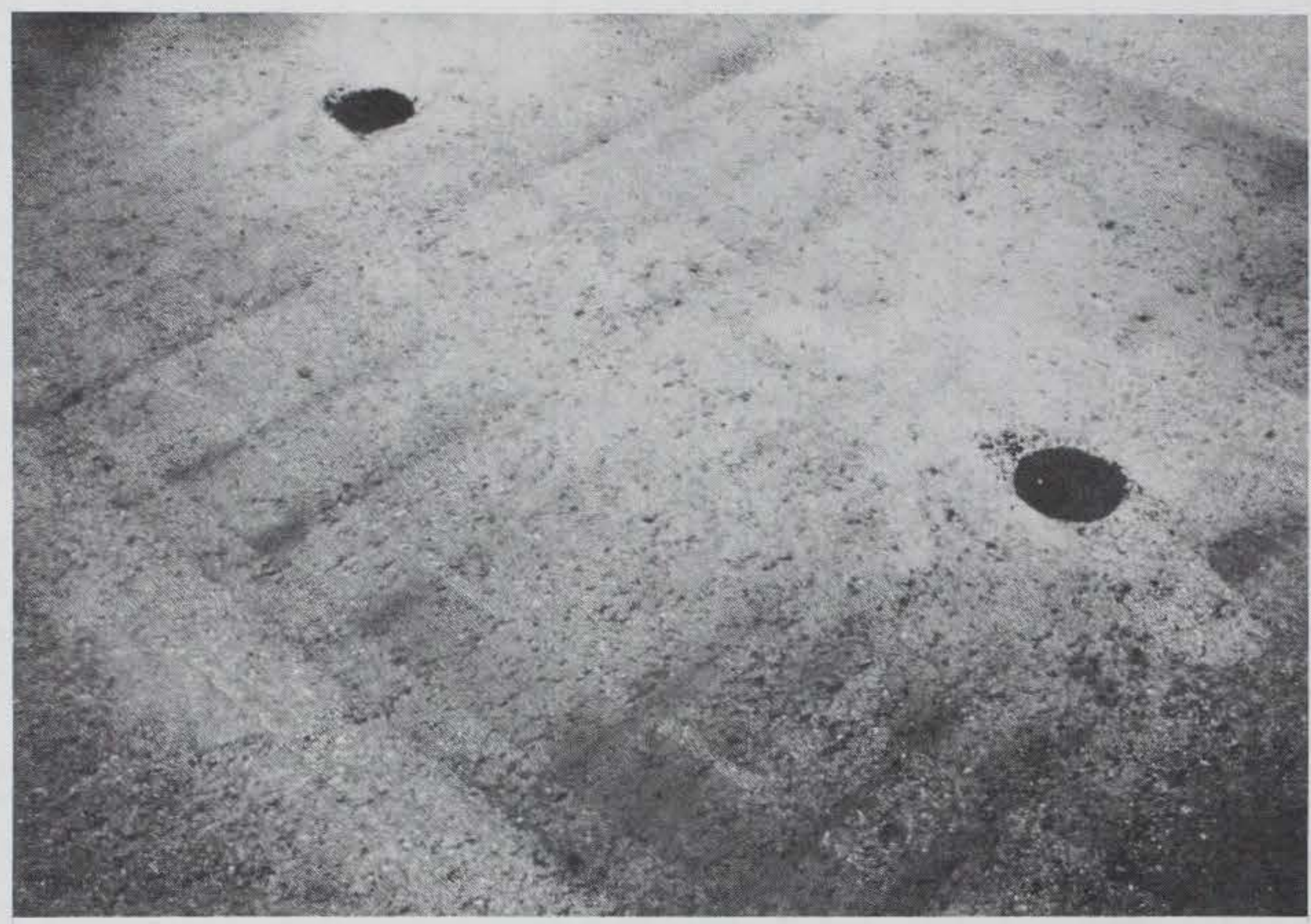

Photo 1. Typical slab sample dimensions

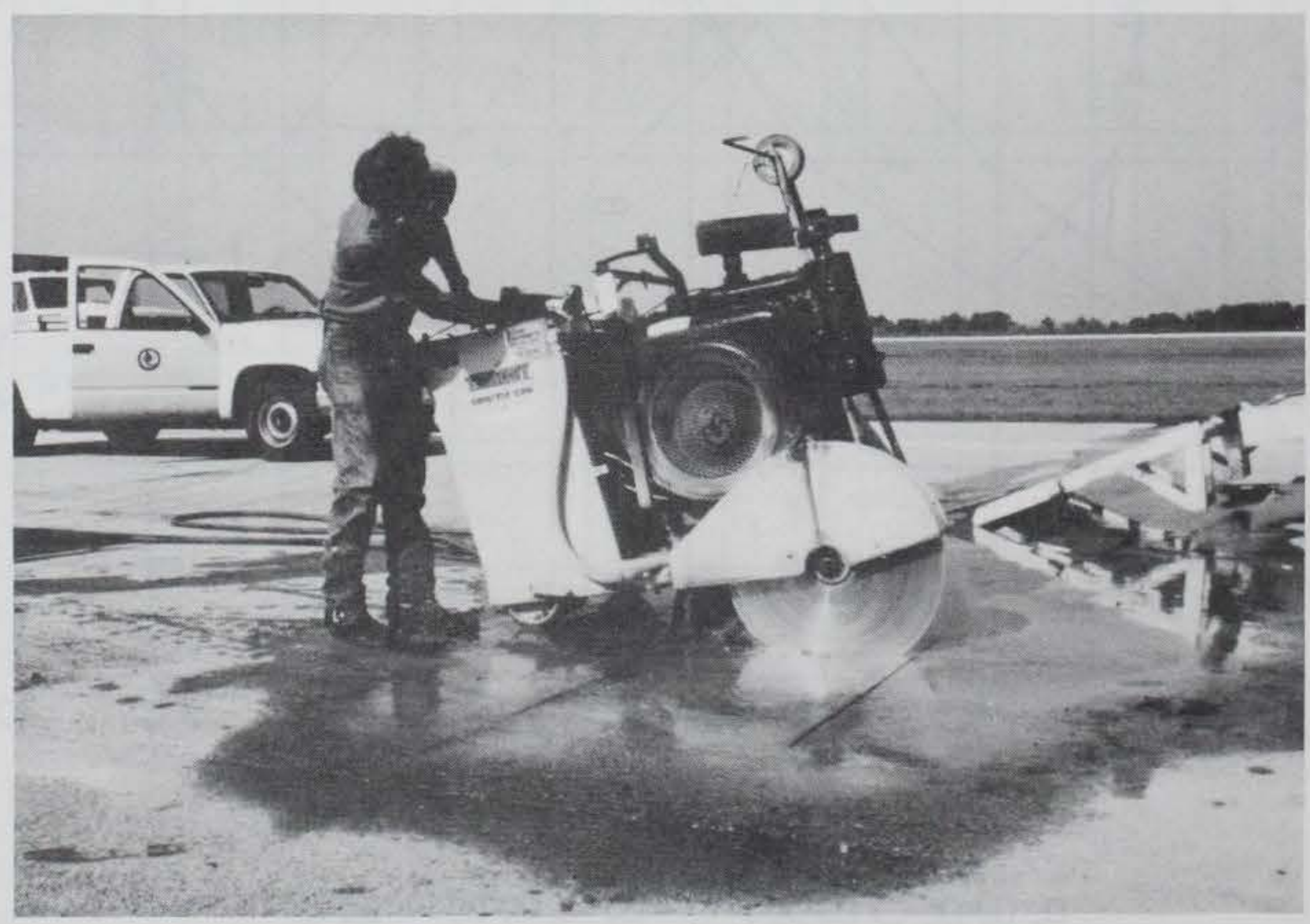

Photo 2. Concrete saw used to remove slab samples 


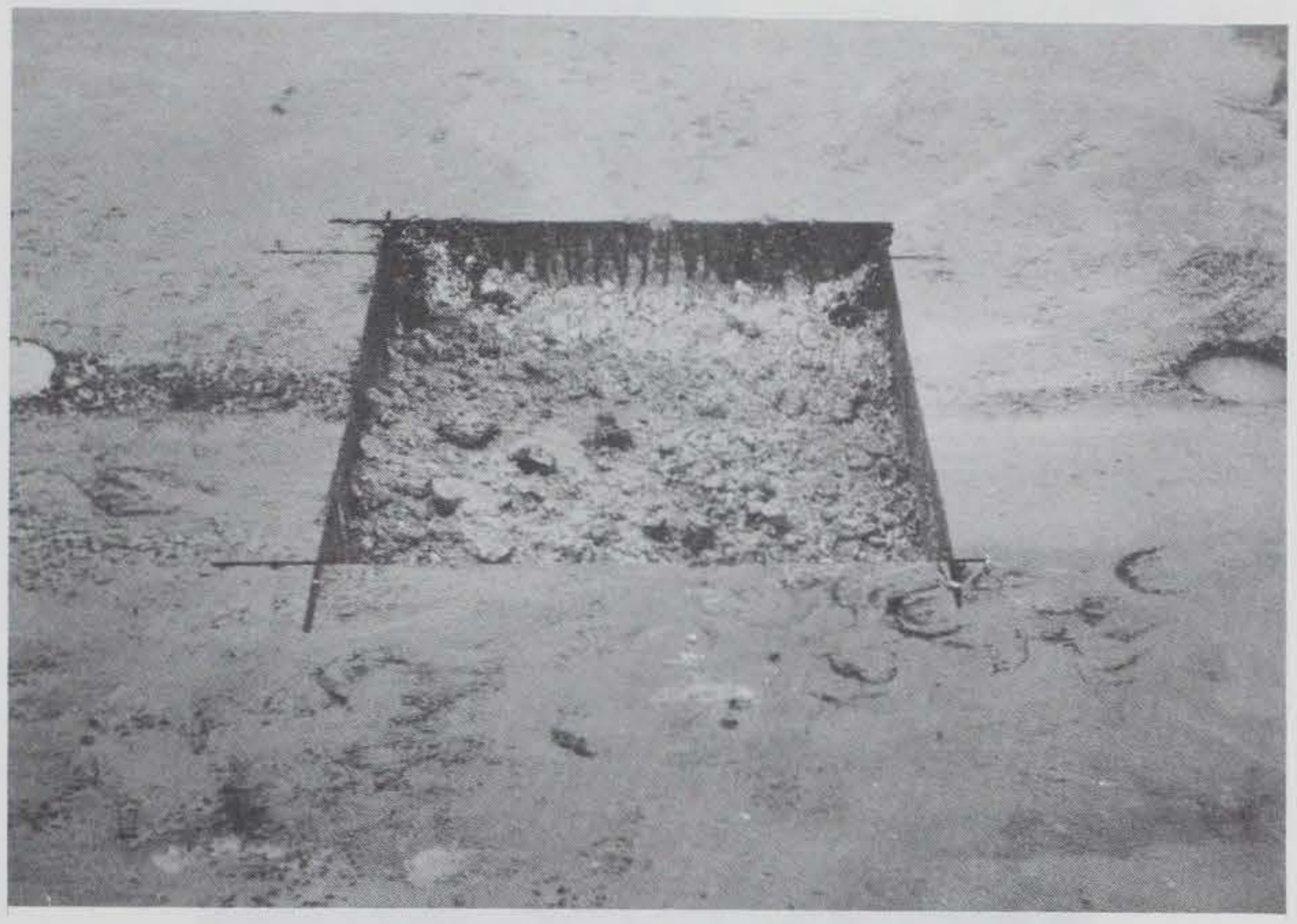

Photo 3. Typical view of removed slab sample

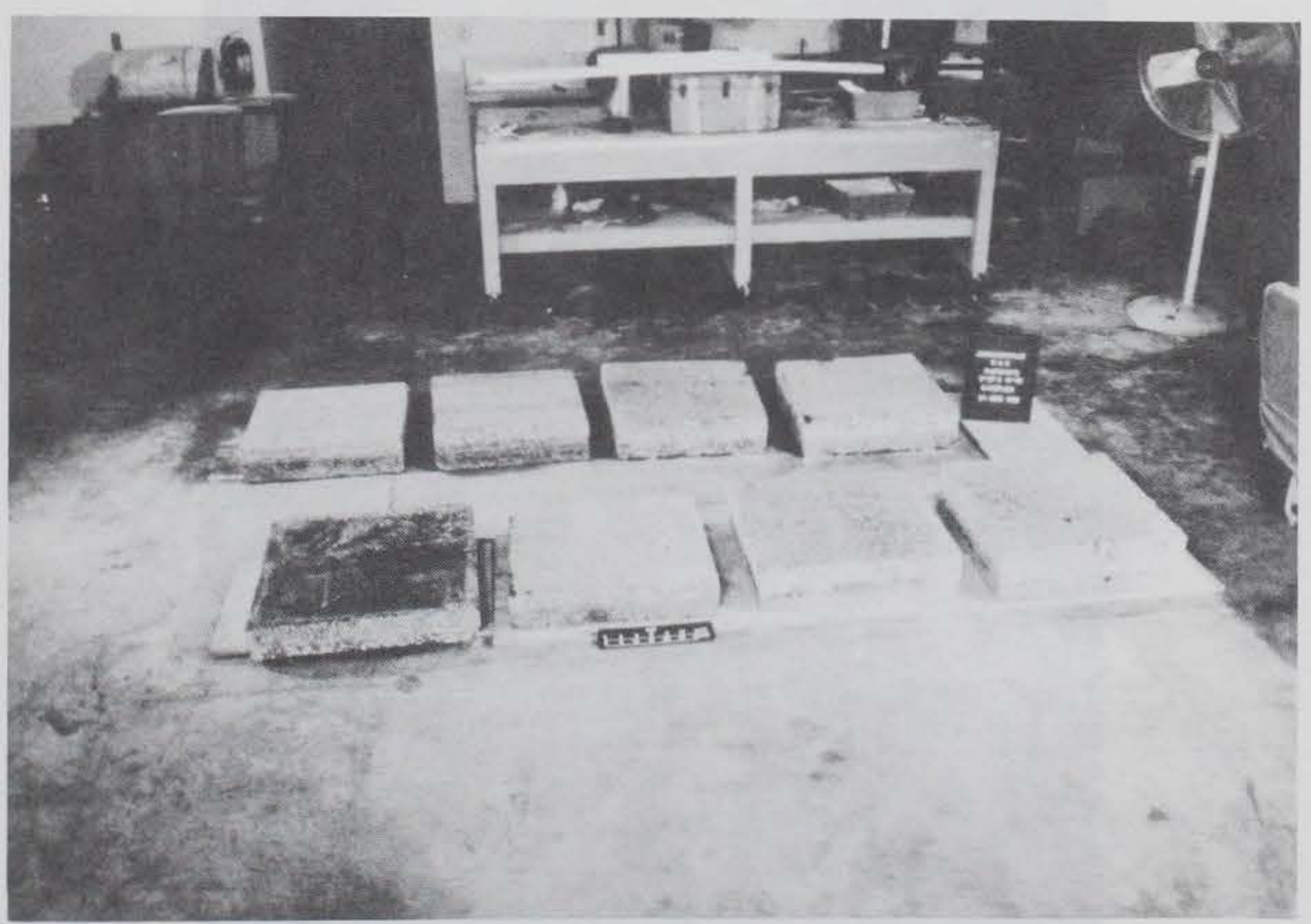

Photo 4. Overall view of eight slab samples 


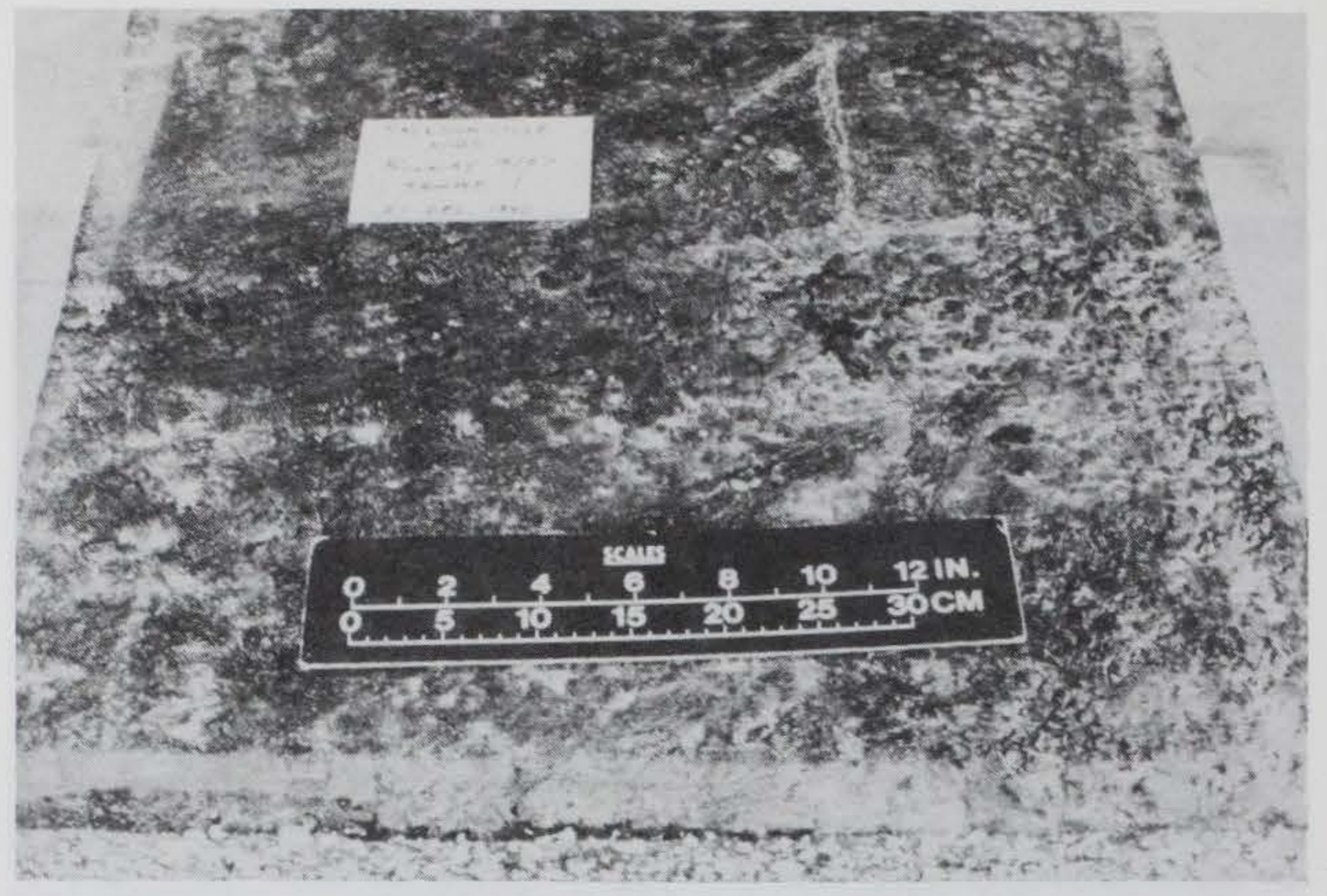

Photo 5. Pavement surface - Slab 1

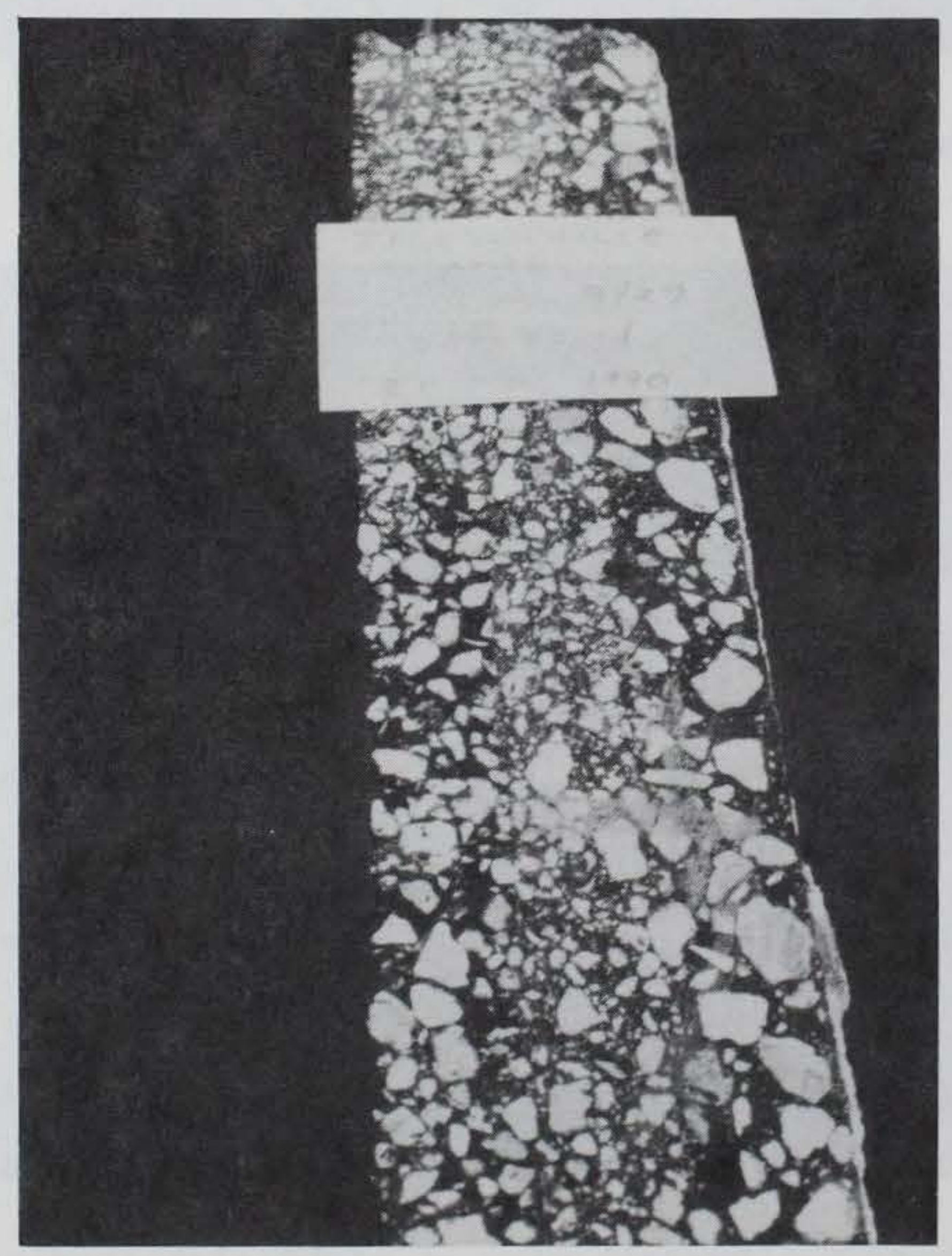

Photo 6. Cross section - Slab 1 


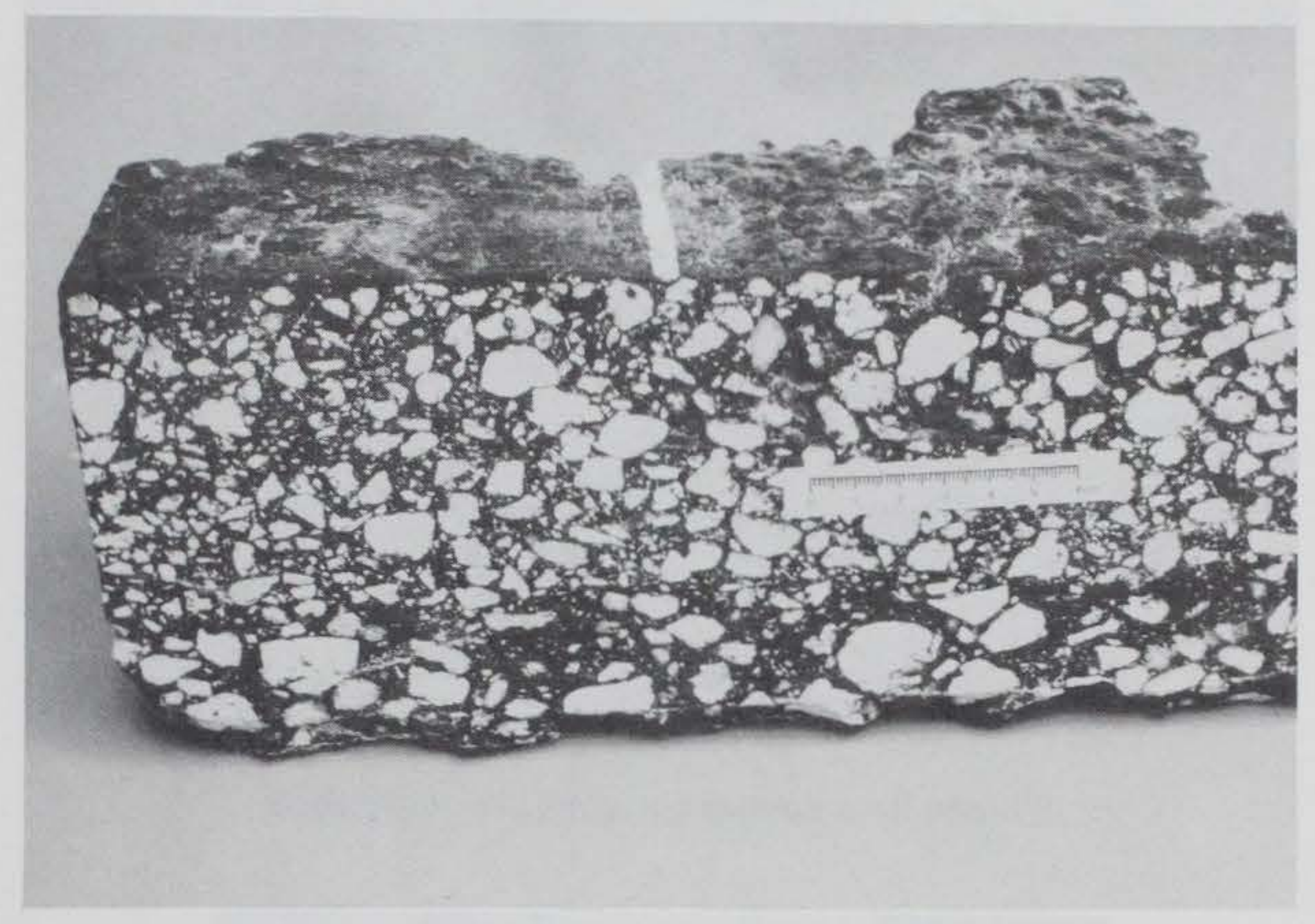

Photo 7. Sawed face of Slab 1

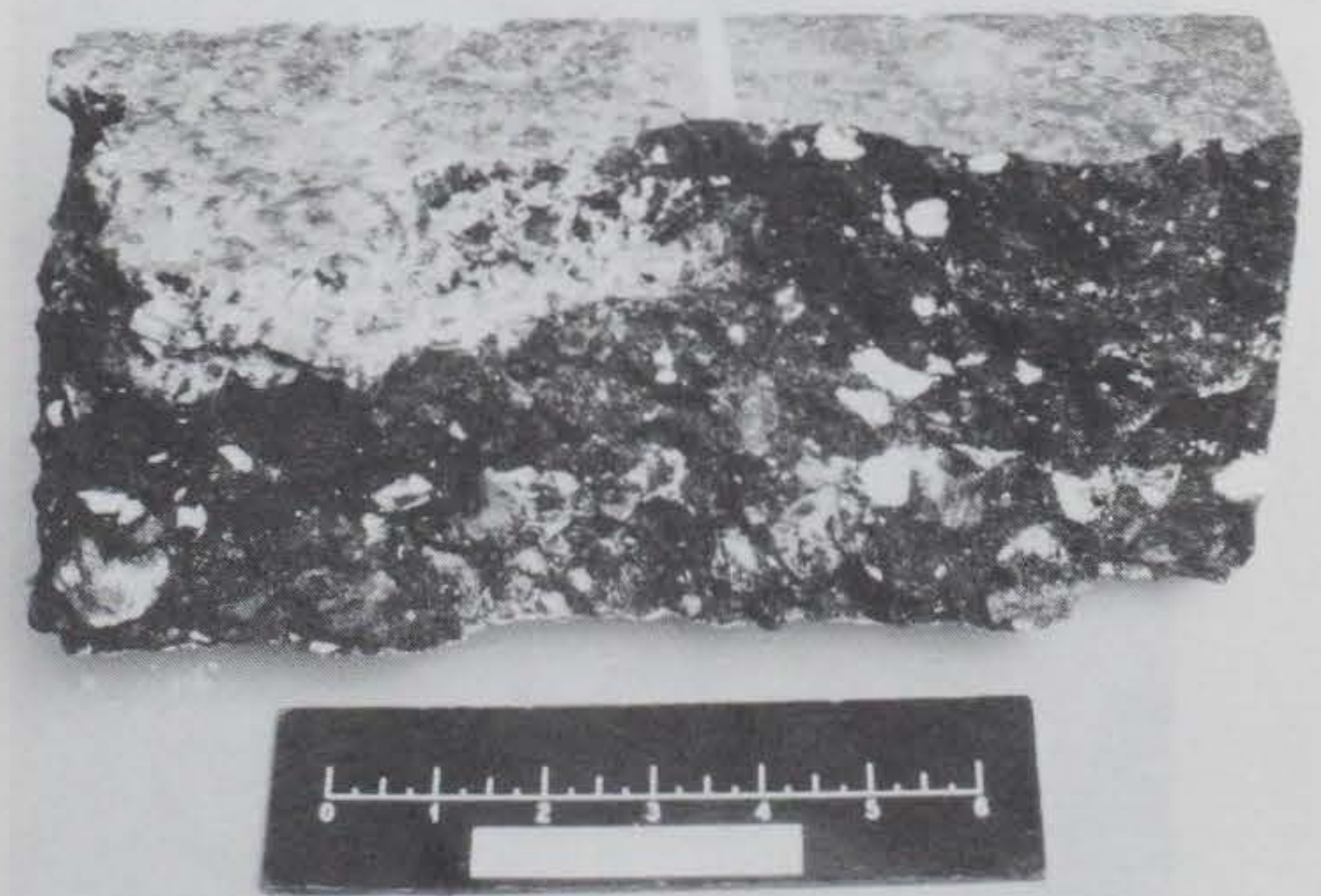

Photo 8. Broken face of Slab 1 


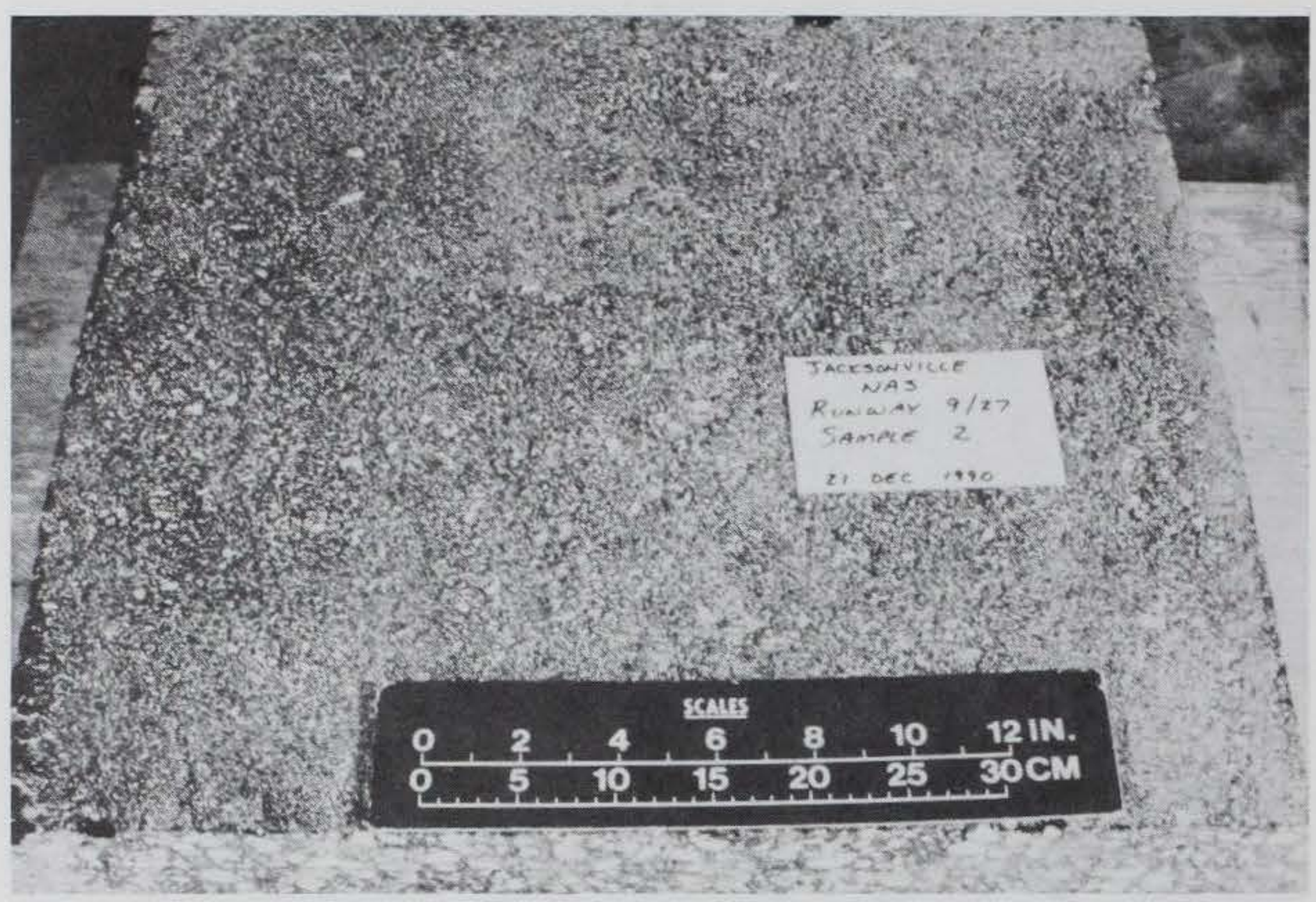

Photo 9. Pavement surface - Slab 2

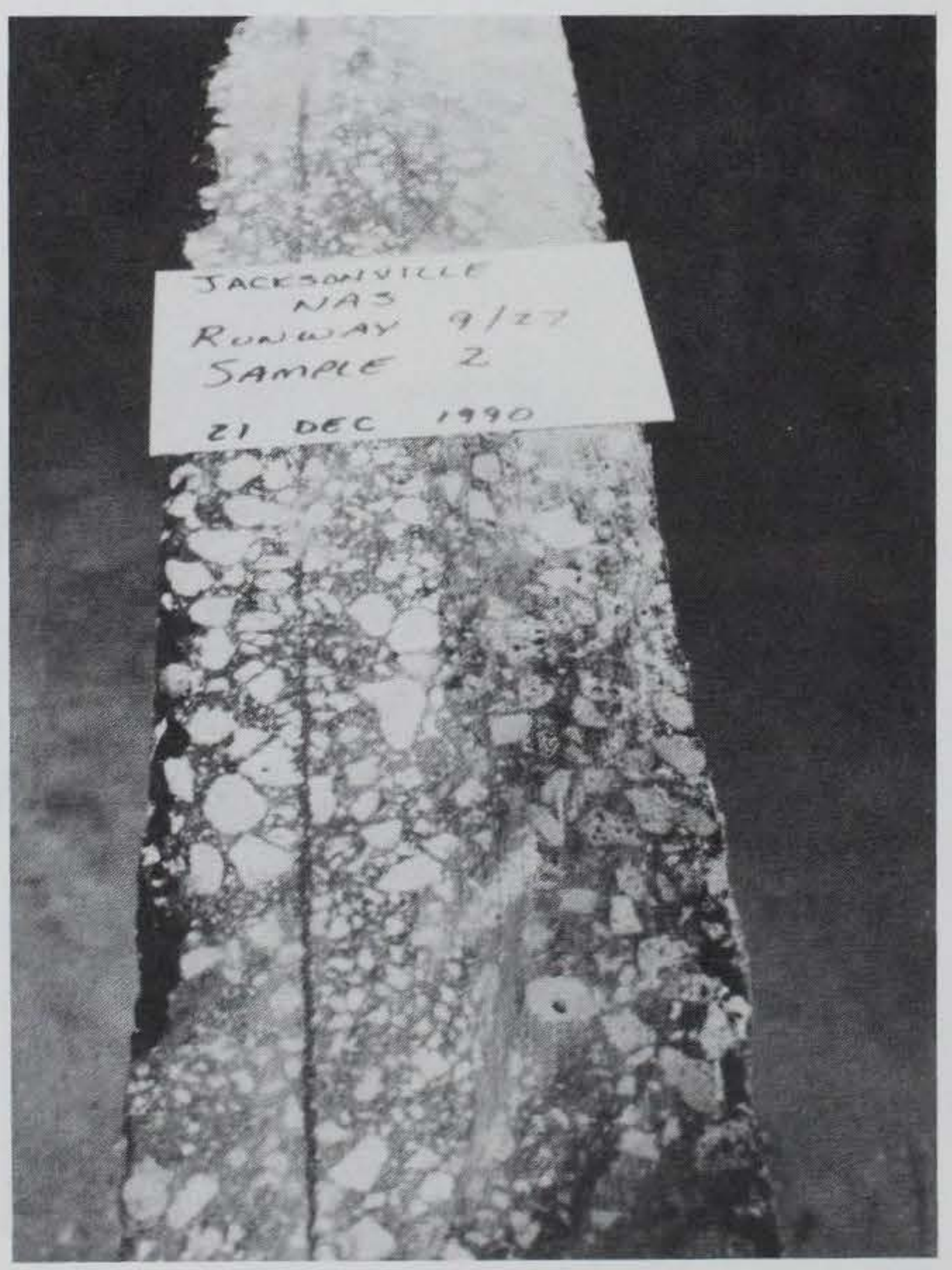

Photo 10. Cross section - Slab 2 


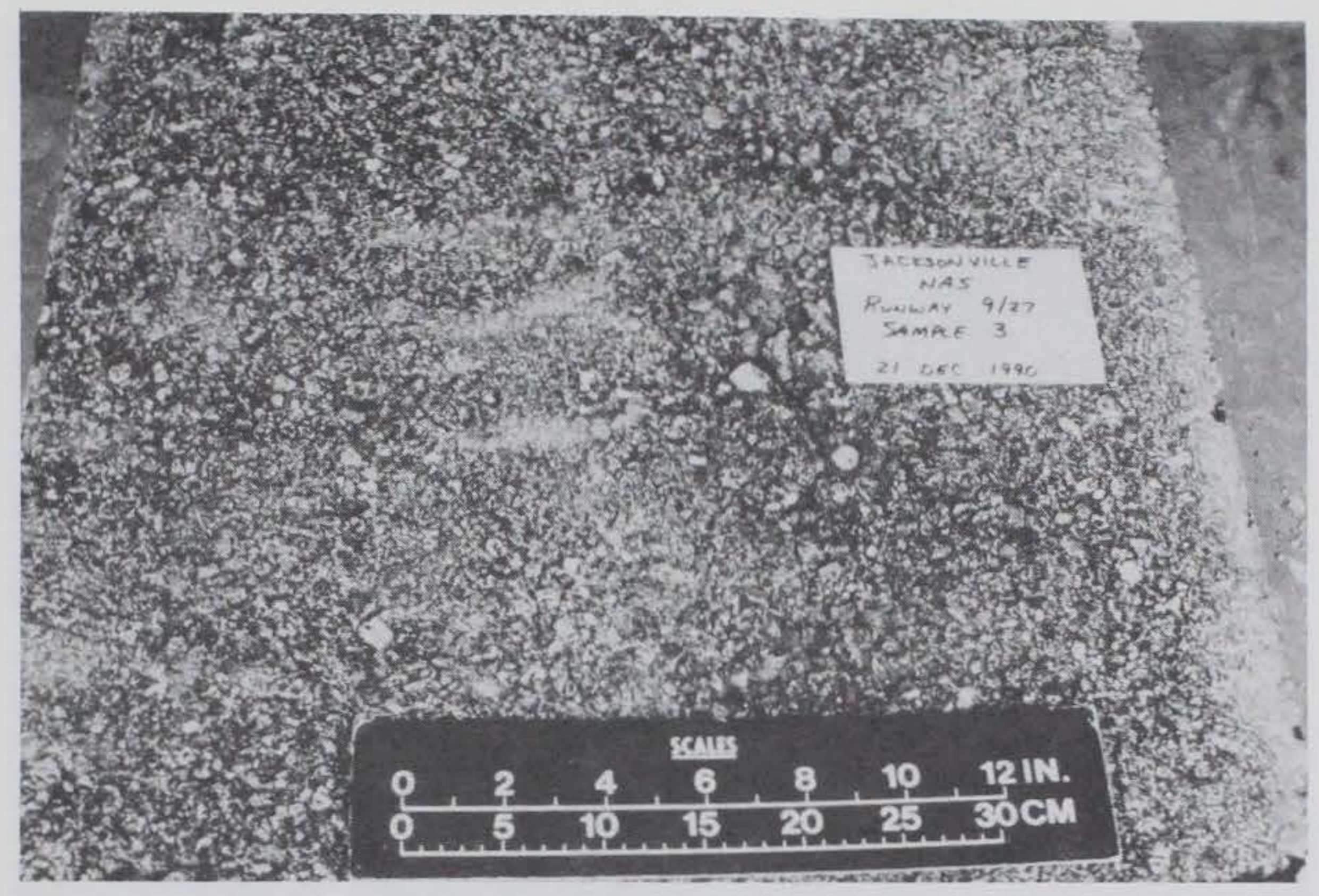

Photo 11. Pavement surface - Slab 3

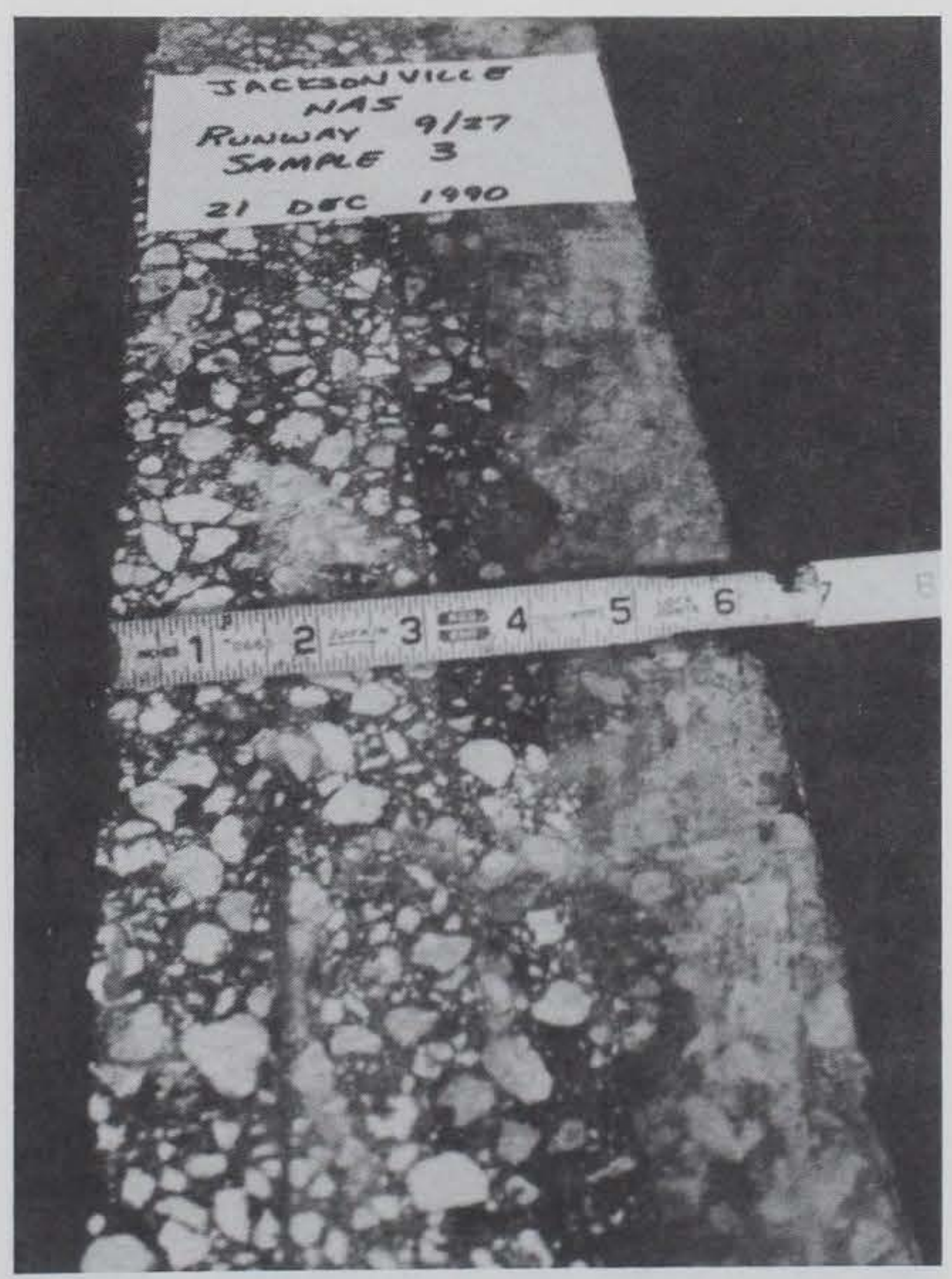

Photo 12. Cross section - Slab 3 


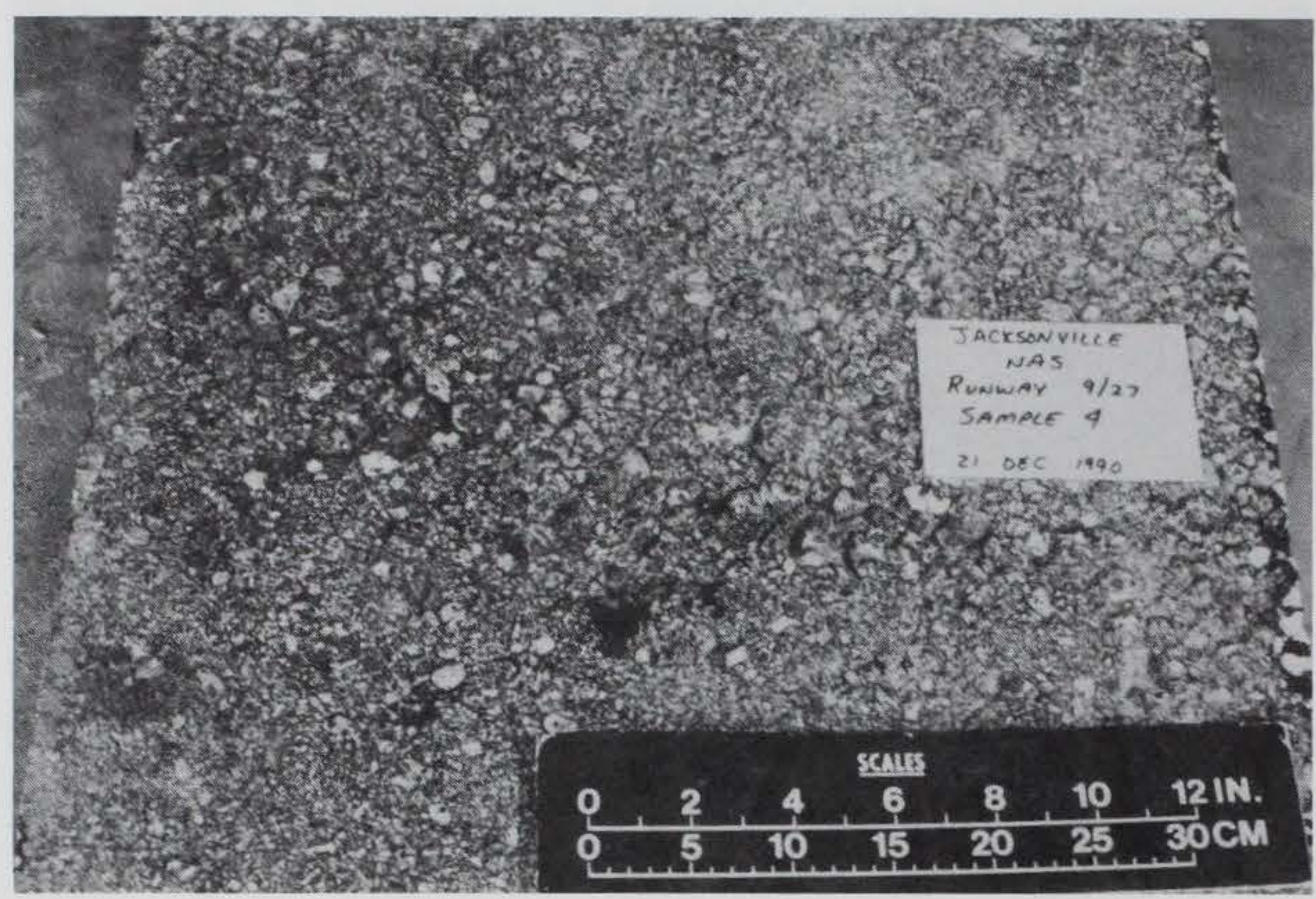

Photo 13. Pavement surface - Slab 4

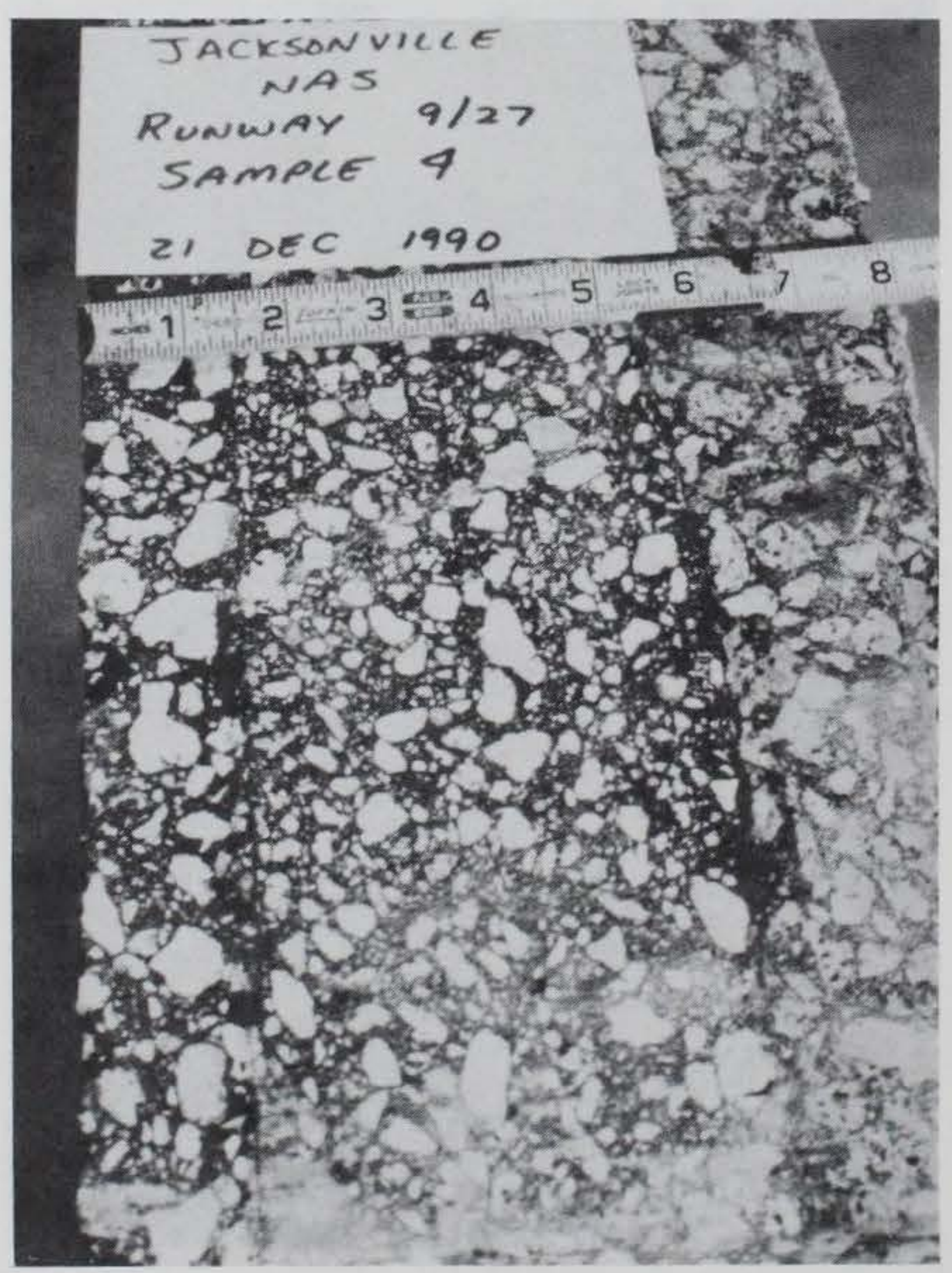

Photo 14. Cross section - Slab 4 


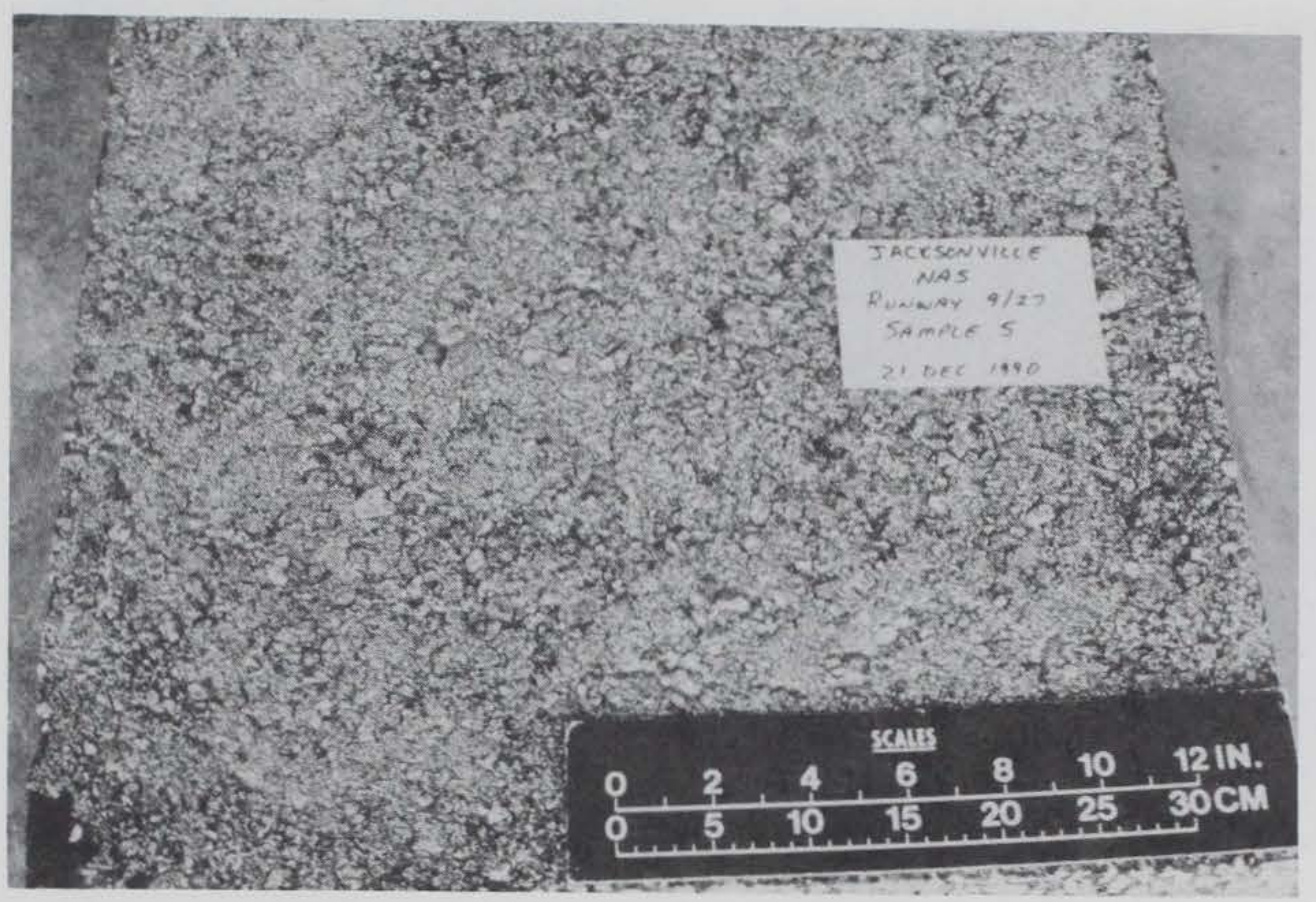

Photo 15. Pavement surface - Slab 5

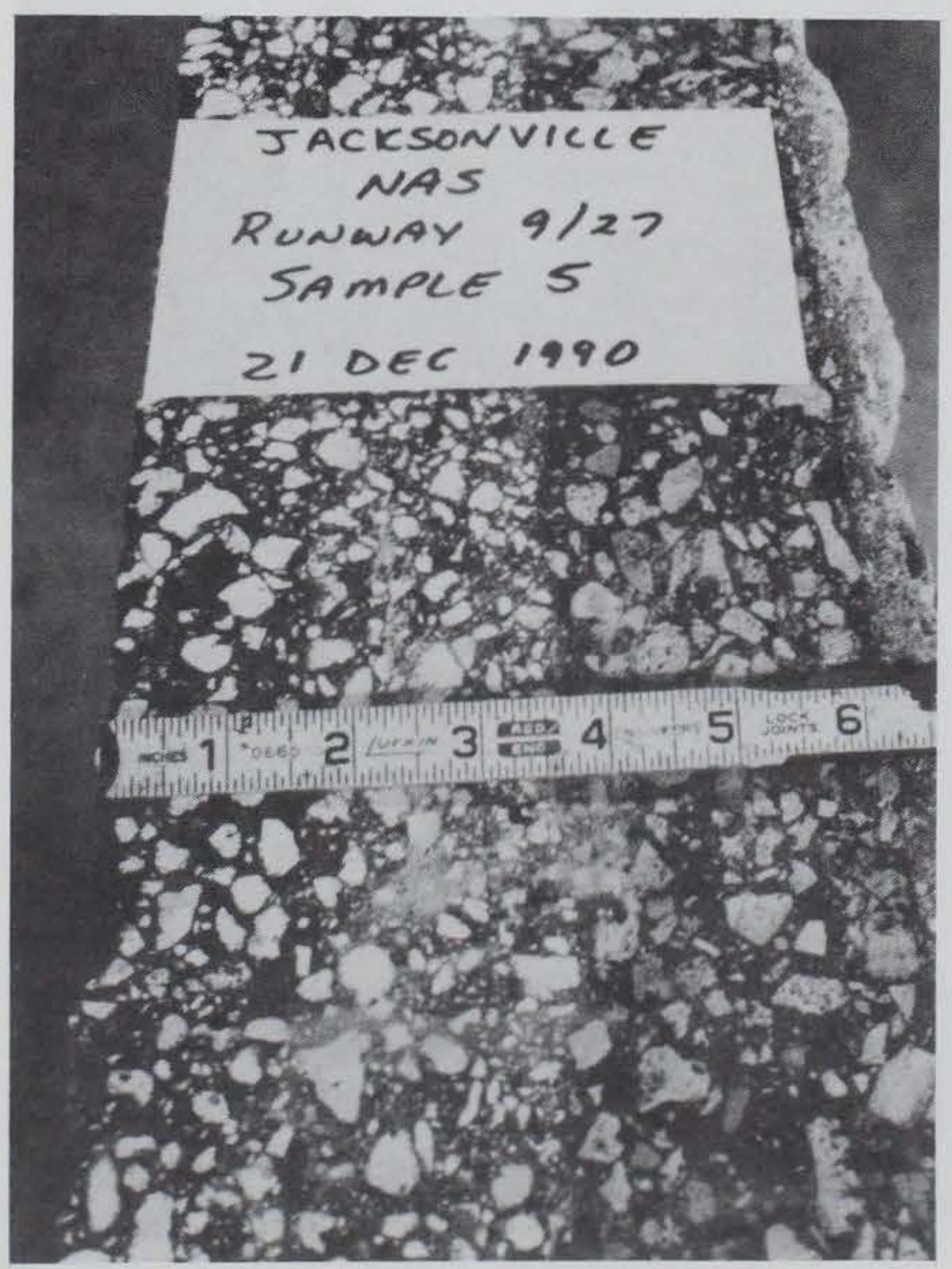

Photo 16. Cross section - Slab 5 


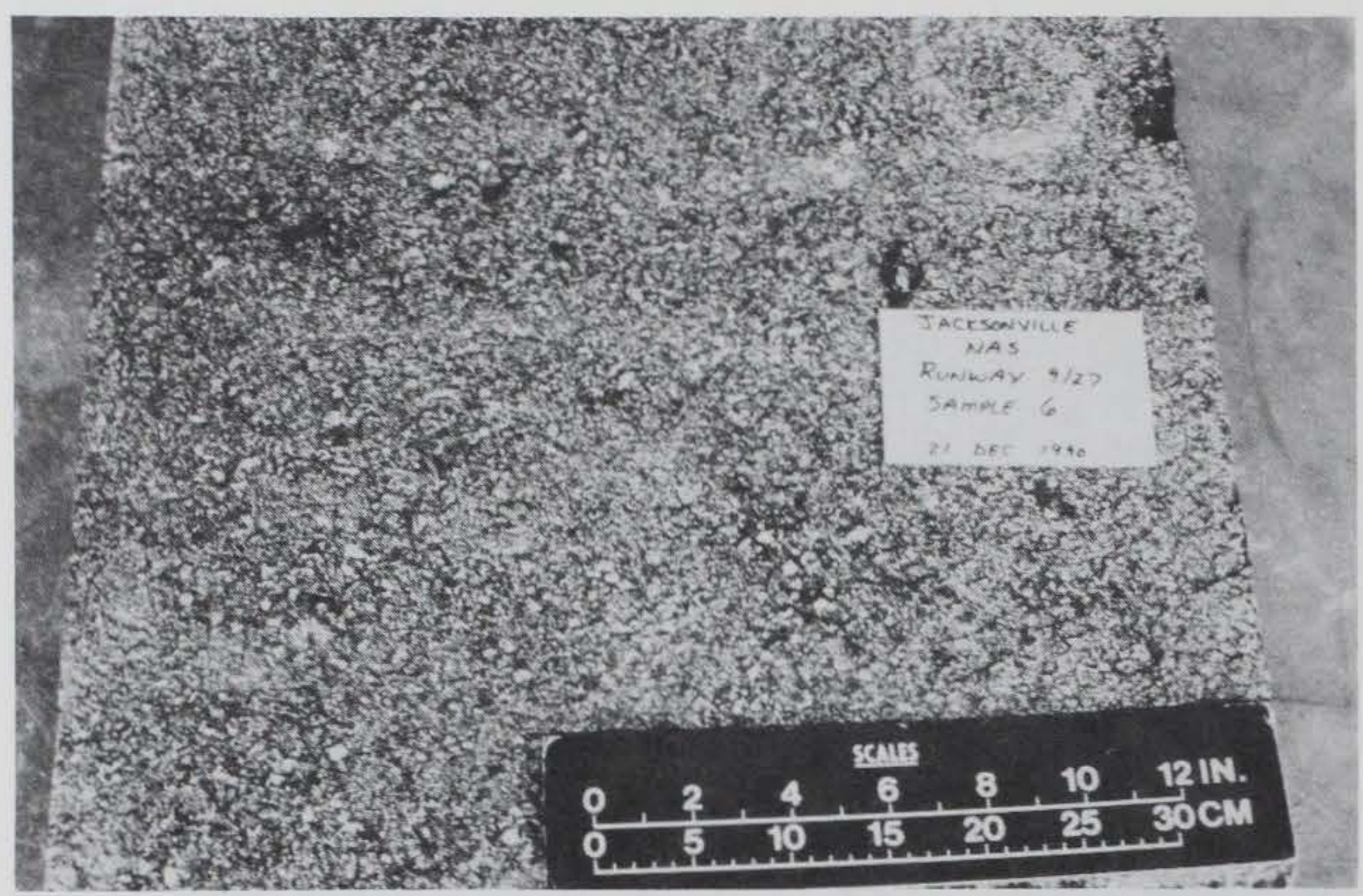

Photo 17. Pavement surface - S1ab 6

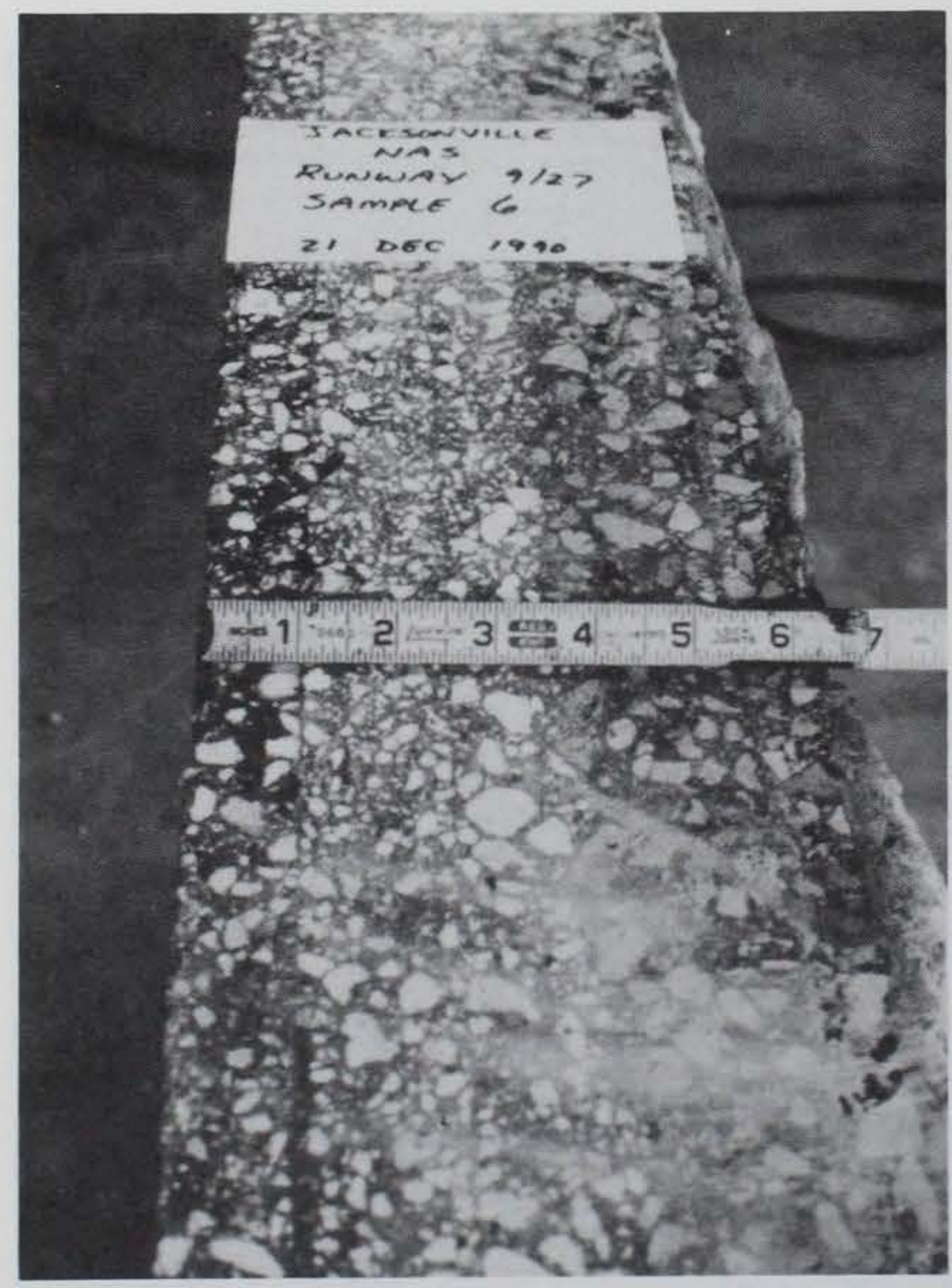

Photo 18. Cross section - Slab 6 


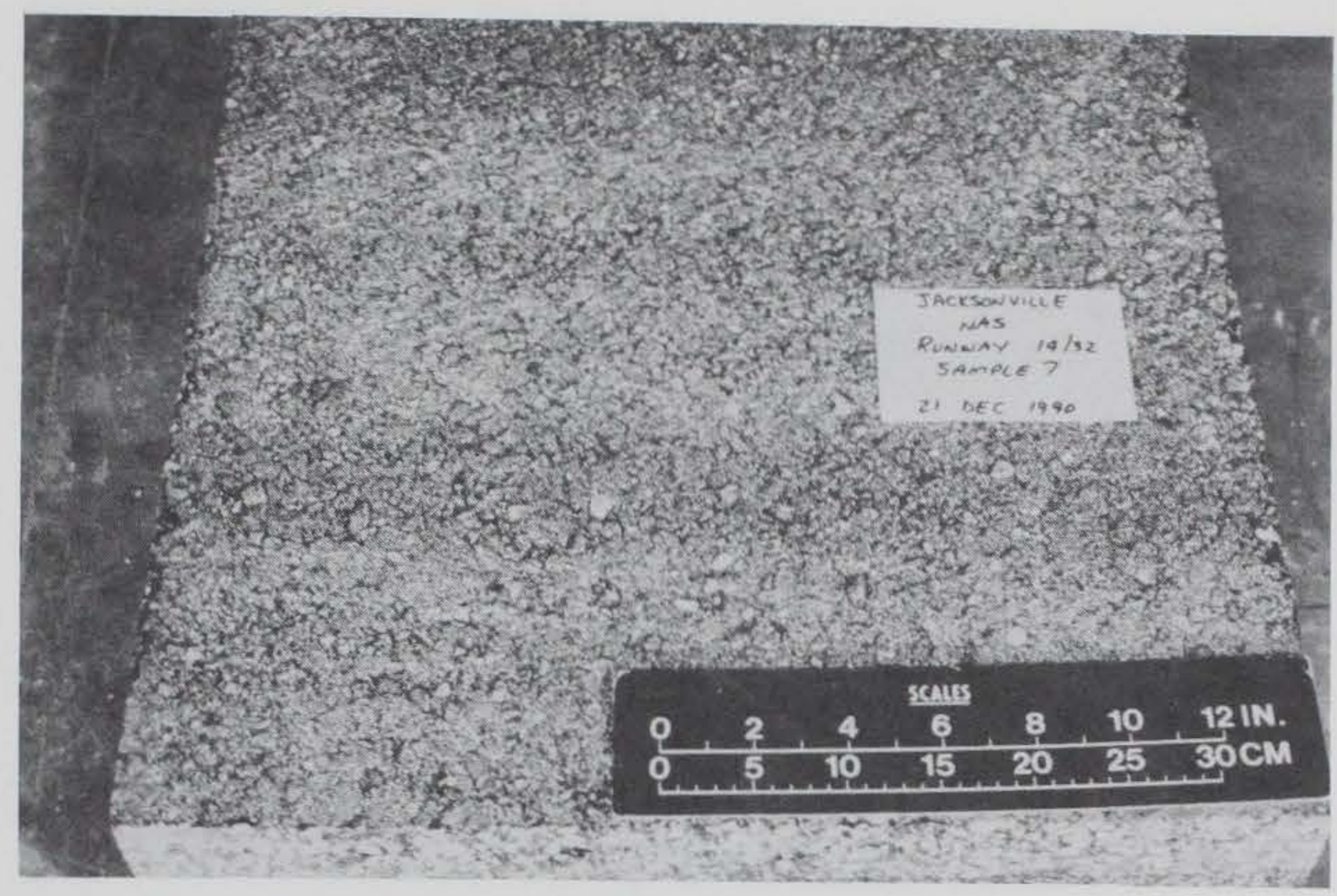

Photo 19. Pavement surface - Slab 7

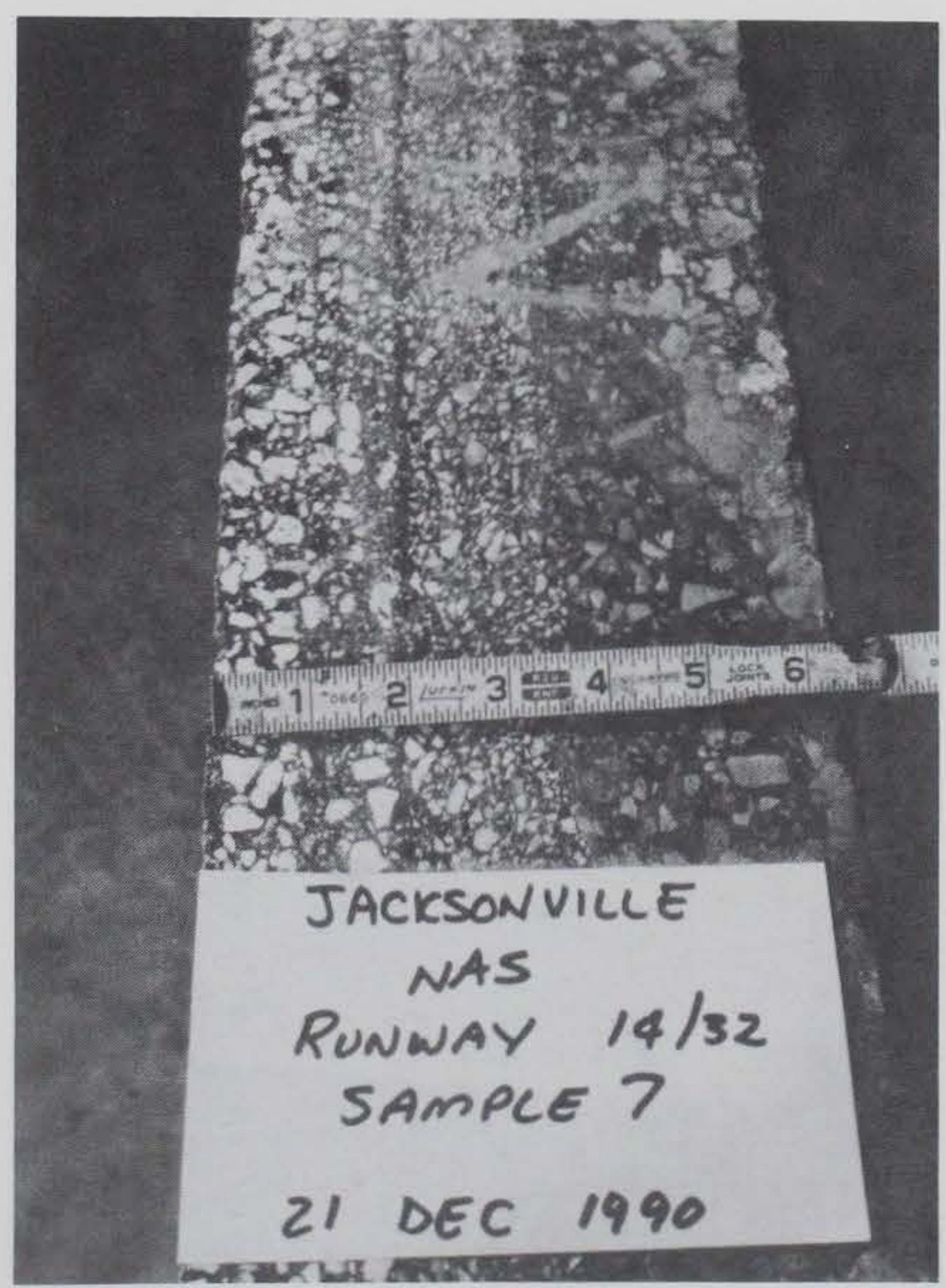

Photo 20. Cross section - Slab 7 


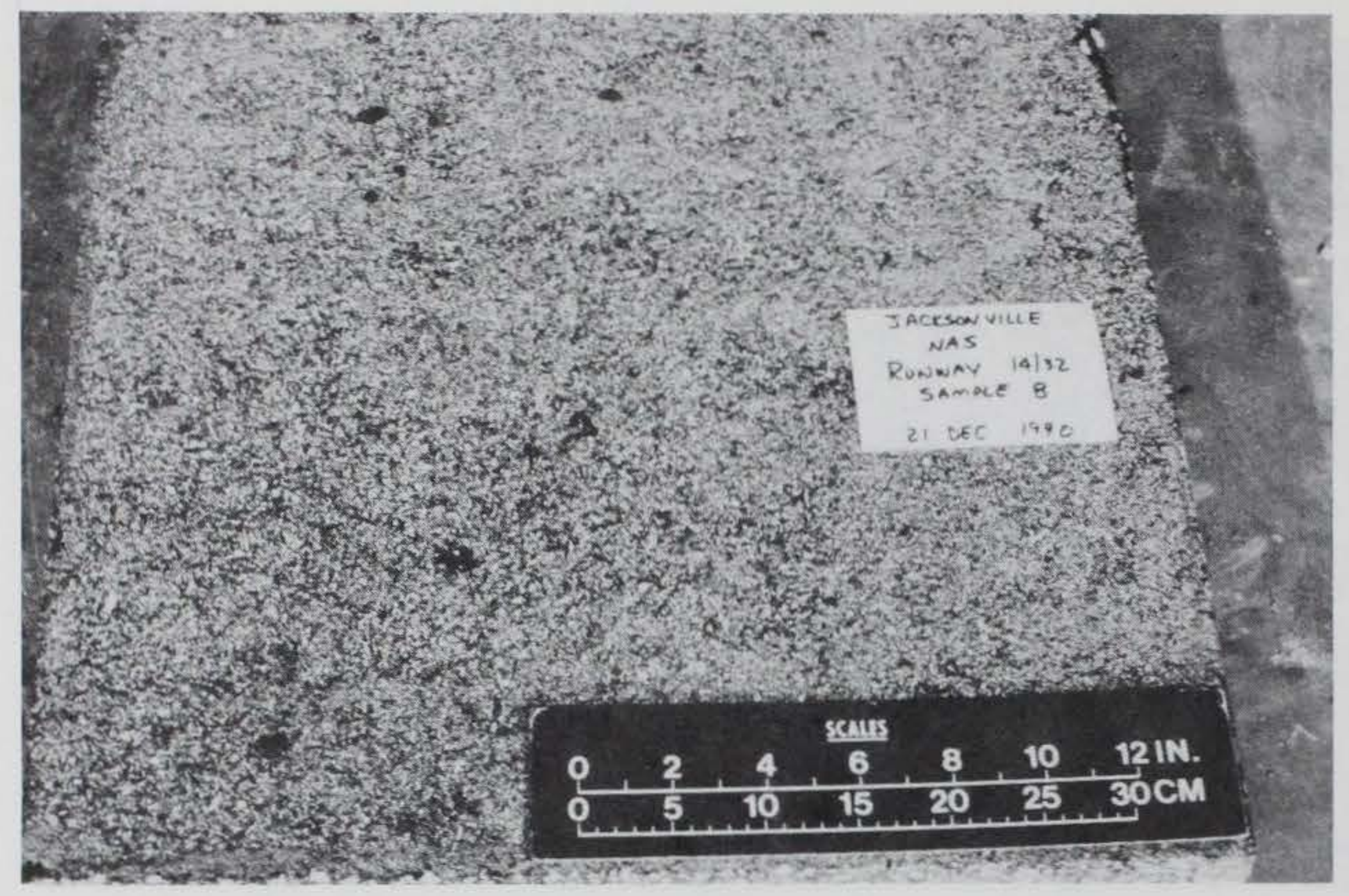

Photo 21. Pavement surface - Slab 8

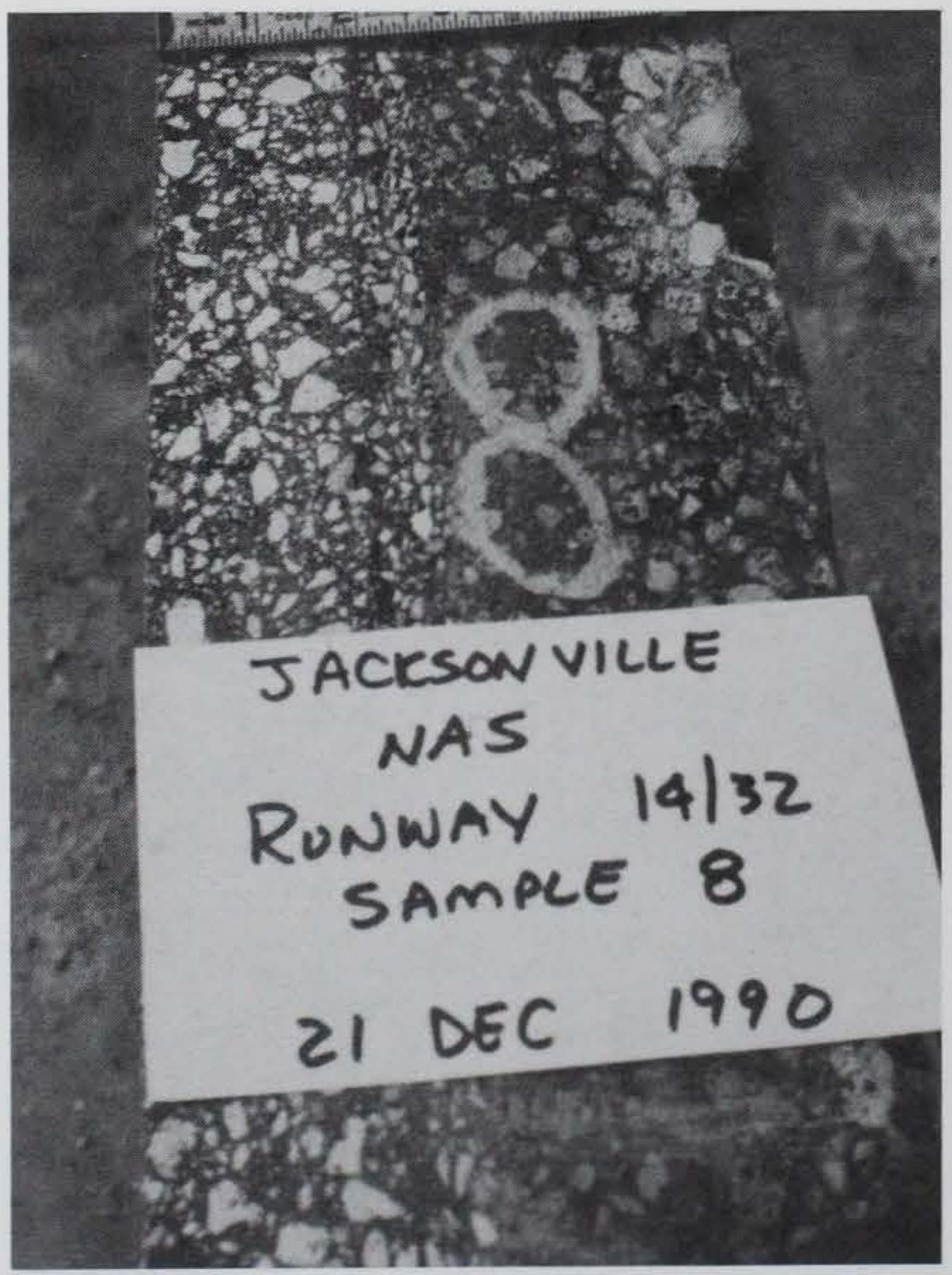

Photo 22. Cross section - S1ab 8 
APPENDIX A: FIELD INSPECTION OF AIRFIELD RUNWAYS AT JACKSONVILLE NAS 


\section{MEMORANDUM FOR RECORD}

SUBJECT: Inspection of Runway 9/27-Jacksonville Naval Air Station

1. Messrs. Nelson Godwin and Randy Ahlrich, U.S. Army Engineer Waterways Experiment Station (WES), Geotechnical Laboratory, Pavement Systems Division, visited Jacksonville Naval Air Station, Florida, on 6 November 1990 to inspect and evaluate the airfield pavement. WES was requested by the Southern Division, Naval Facilities Engineering Command, Charleston, South Carolina, to provide technical assistance in the inspection of Runway 9/27. Personnel involved with the inspection of the airfield pavement included the following:
a. CDR J. C. Knol1, ROICC.
b. Larry Blackburn, ROICC.
c. Pat Haley, ROICC.
d. Mike Wade1, ROICC.
e. Wilbert Beverly, Southern Division.
f. Bill Meyer, Airfield Operations.
g. ABH2 Dale Nelson, Airfield Operations.
h. Tommy Surrency, PWD (FMED).
i. CPT Rick Sloop, PWD (FMED).
j. Nelson Godwin, WES .
k. Randy Ahlrich, WES.

2. Jacksonville NAS renovated Runways $14 / 32$ and $9 / 27$ during 1988 . Runway $14 / 32$ was rehabilitated with a 1 1/2-inch asphalt concrete overlay. An asphalt mixture with a $1 / 2$-inch maximum aggregate gradation was used to resurface this pavement. The rehabilitation of Runway $9 / 27$ included cold milling the existing asphalt pavement and placing a minimum of 3 inches of asphalt concrete. A $3 / 4$-inch maximum aggregate gradation was used in the asphalt concrete for Runway $9 / 27$. The wearing course for Runway $9 / 27$ was completed in December 1988.

3. In December 1989 , the airfield manager and the maintenance department noticed large amounts of fine aggregate on the pavement surface. Since that time, the pavement surface has continued to deteriorate. Several inspections of the runway had been conducted since December 1989. The primary defects reported for the pavement surface included raveling, segregation, and the evidence of roots in the asphalt concrete mixture. 
CEWES - GP-Q

SUBJECT: Inspection of Runway 9/27-Jacksonville Naval Air Station

4. On 6 November 1990 , the airfield pavement was inspected during the normal maintenance shut down period, 0800-1000. The overall appearance of Runway $9 / 27$ indicated the asphalt concrete material was losing the fine aggregate and raveling. The touchdown zone area near the center line was exhibiting the most severe raveling. The pavement had excessive rubber build-up and an opentextured appearance. Figures 1 and 2 show the typical condition of Runway 9/27. Specific observations and defects observed in Runway $9 / 27$ are listed below:

a. Medium to severe raveling had occurred in the pavement surface. Raveling was more severe near the center line but was also occurring in the non-traffic areas (Figure 3-5).

b. Crushed and fractured limerock was exposed on the pavement surface (Figure 6).

c. Large amounts of roots were observed in asphalt concrete mixture (Figures 7 and 8 ). Aggregate materials around the roots were not coated with asphalt cement.

d. Uncoated natural sand material was evident under some aggregates.

e. Coarse and fine aggregates were not coated with asphalt cement. Water was evident which could indicate a stripping problem.

f. Surface texture was rough and had small tears and cracks, which may be the result of improper laydown techniques and rolling operations.

g. Some of the open-textured asphalt material existed prior to traffic (Figure 9).

h. Two distinctive colors in asphalt concrete material (Figure 10).

i. Ravelled material and stains on longitudinal construction joint (Figure 11).

5. Based on the visual inspection of Runway $9 / 27$ and the discussion with Jacksonville NAS personnel, possible causes of the pavement deterioration are listed below:

a. Exposed aggregate was due to breakage of soft Florida limerock during construction and under traffic.

b. The large amount of roots in the asphalt concrete mixture indicated a "dirty" natural sand was used.

c. Uncoated coarse and fine aggregate particles may have been caused by any of the following: 
CEWES - GP-Q

SUBJECT: Inspection of Runway 9/27-Jacksonville Naval Air Station

(1) Low asphalt cement content in the mixture.

(2) Stripping of the asphalt cement from the aggregates.

(3) A high fine aggregate content such as too much natural sand.

d. Paver screed may have been dragging causing tears and small cracks in surface or the rollers may have been going too fast or the mixture was too hot to support the roller.

e. Asphalt mixture was not rolled enough with rubber-tired roller to close small cracks and surface voids.

f. Some of the open texture existed prior to aircraft traffic. Figure 9, which shows a painted area with an open texture, indicates that the open or coarse texture existed at the time the paint was applied, which would have been before opening the runway to aircraft traffic. Therefore, the potential exists that the construction procedures or the aggregate gradation contributed to the open texture condition.

6. Runway $14 / 32$ was also inspected. Defects similar to the ones found on Runway $9 / 27$ were also evident but the degree of deterioration on Runway 14/32 was lower. Because of the short length of Runway $14 / 32$, there was also less traffic than on Runway $9 / 27$.

7. During a briefing after the field inspection, Mr. Godwin and I discussed the pavement distresses and possible causes of the pavement deterioration. We informed the Navy personnel that the pavement deterioration was caused by several factors. Most of these factors dealt with material and mixture properties and could only be verified through laboratory testing. We also stated that the pavement deterioration would continue and possibly reach a state where the pavement would be unusable. Foreign object damage potential is great and will increase.

RANDY C. AHLRICH

Pavement Systems Division

Routing:

1. Godwin

2. Vollor

3. Ulery

4. Hadala

5. Marcuson

6.

7. Edwards/originator/files 


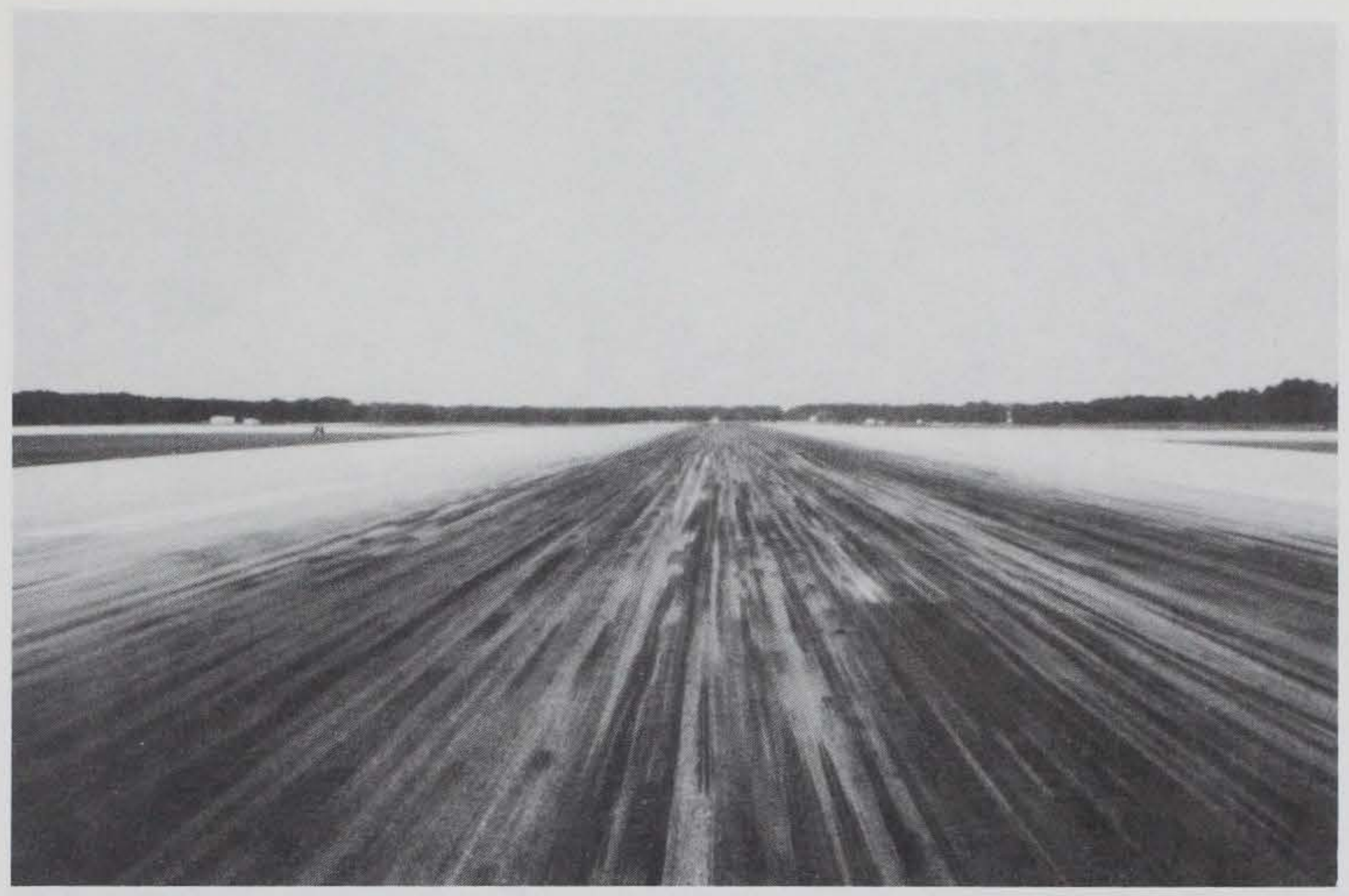

Figure 1. Typical view of Runway $9 / 27$

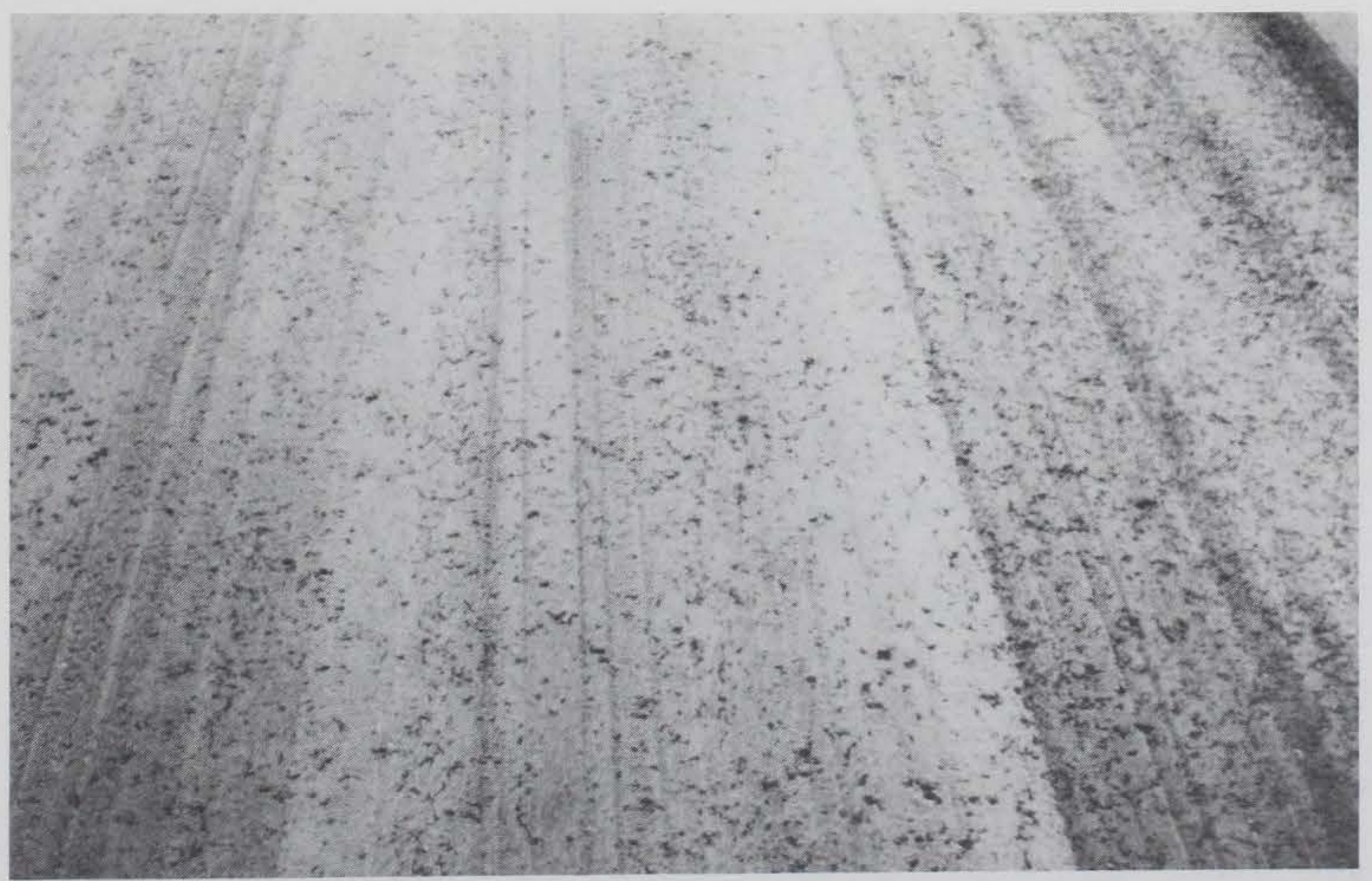

Figure 2. Open-textured asphalt mixture with rubber build-up 


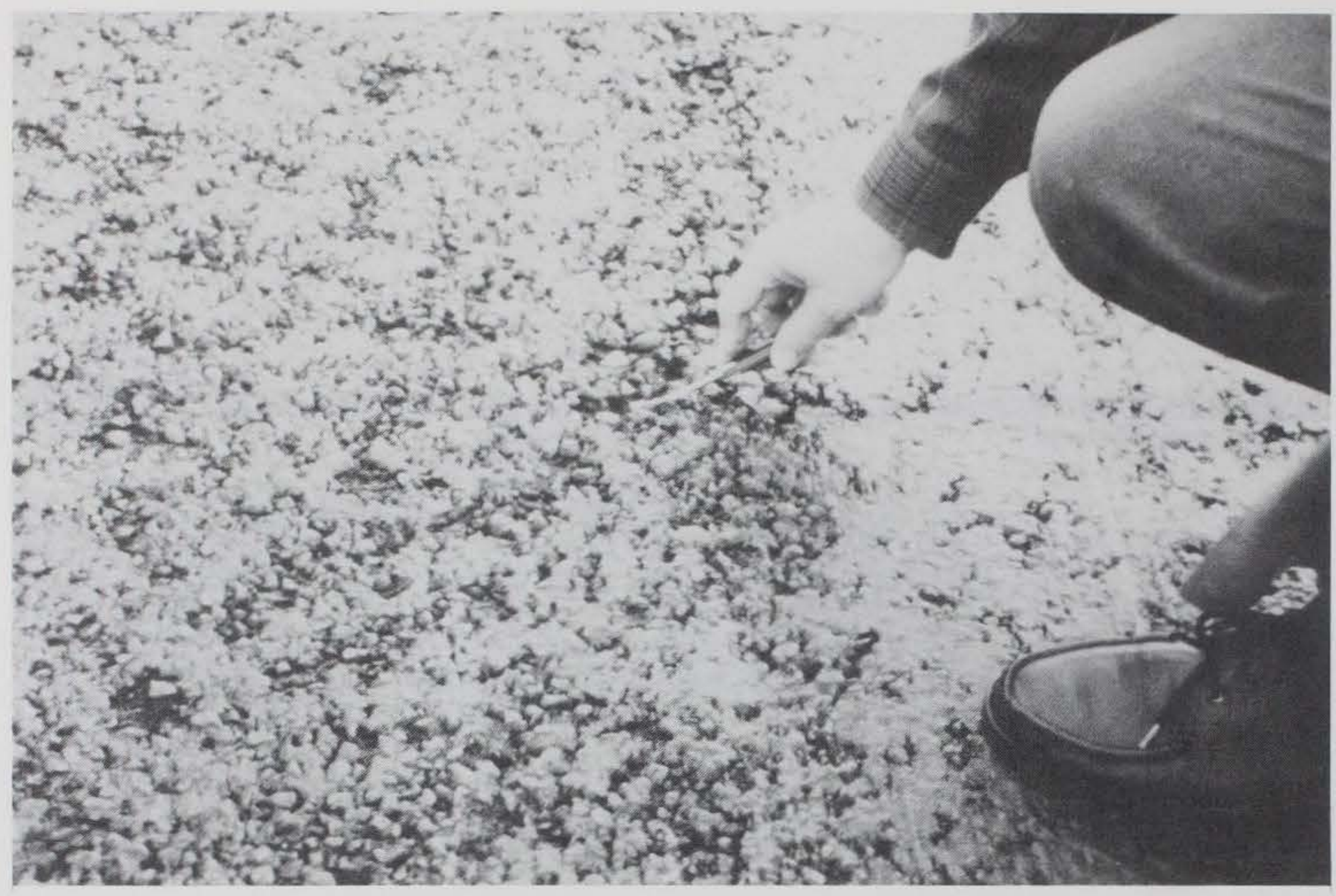

Figure 3. Severe raveling near centerline.

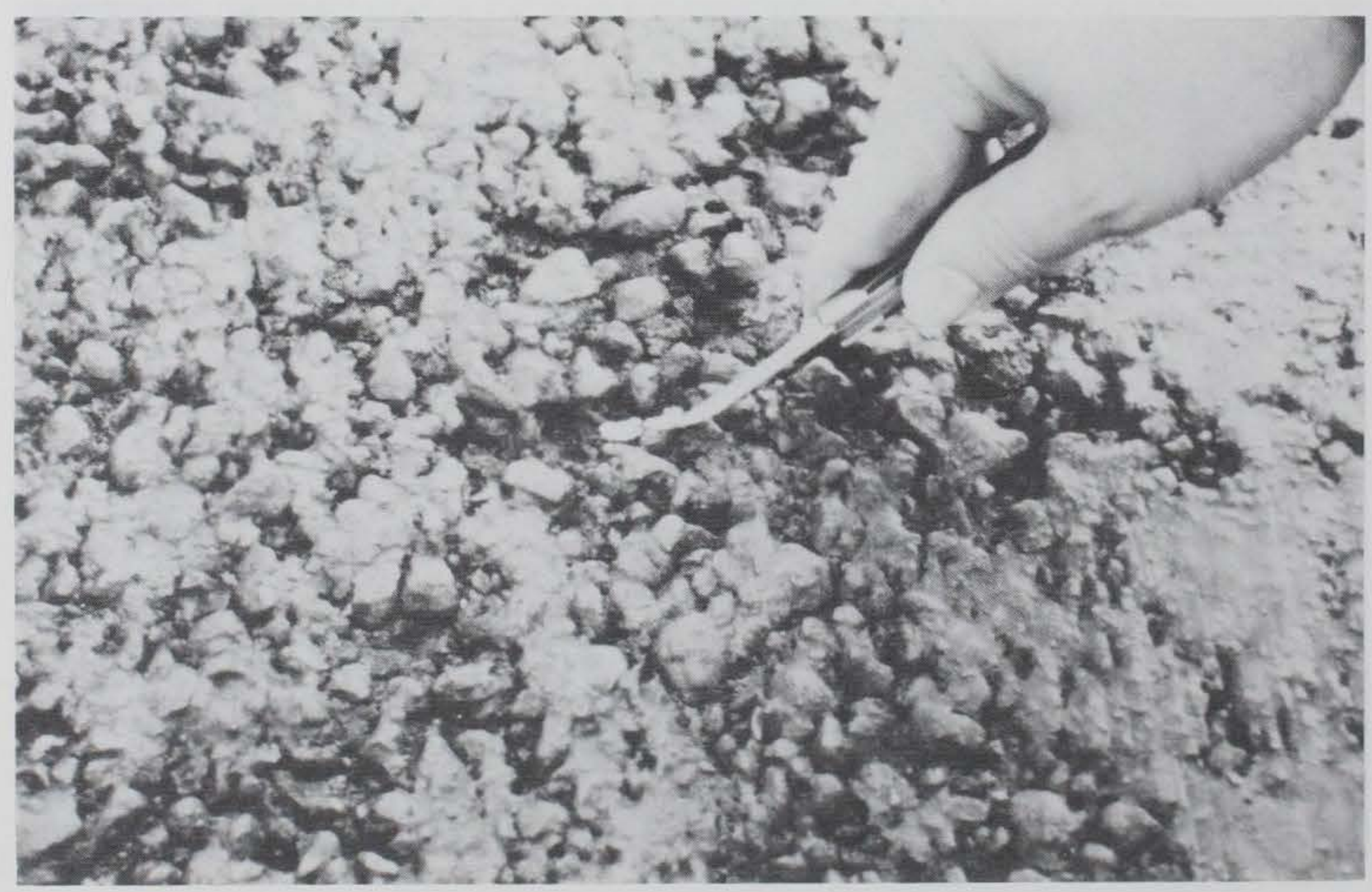

Figure 4. Close-up of raveling 


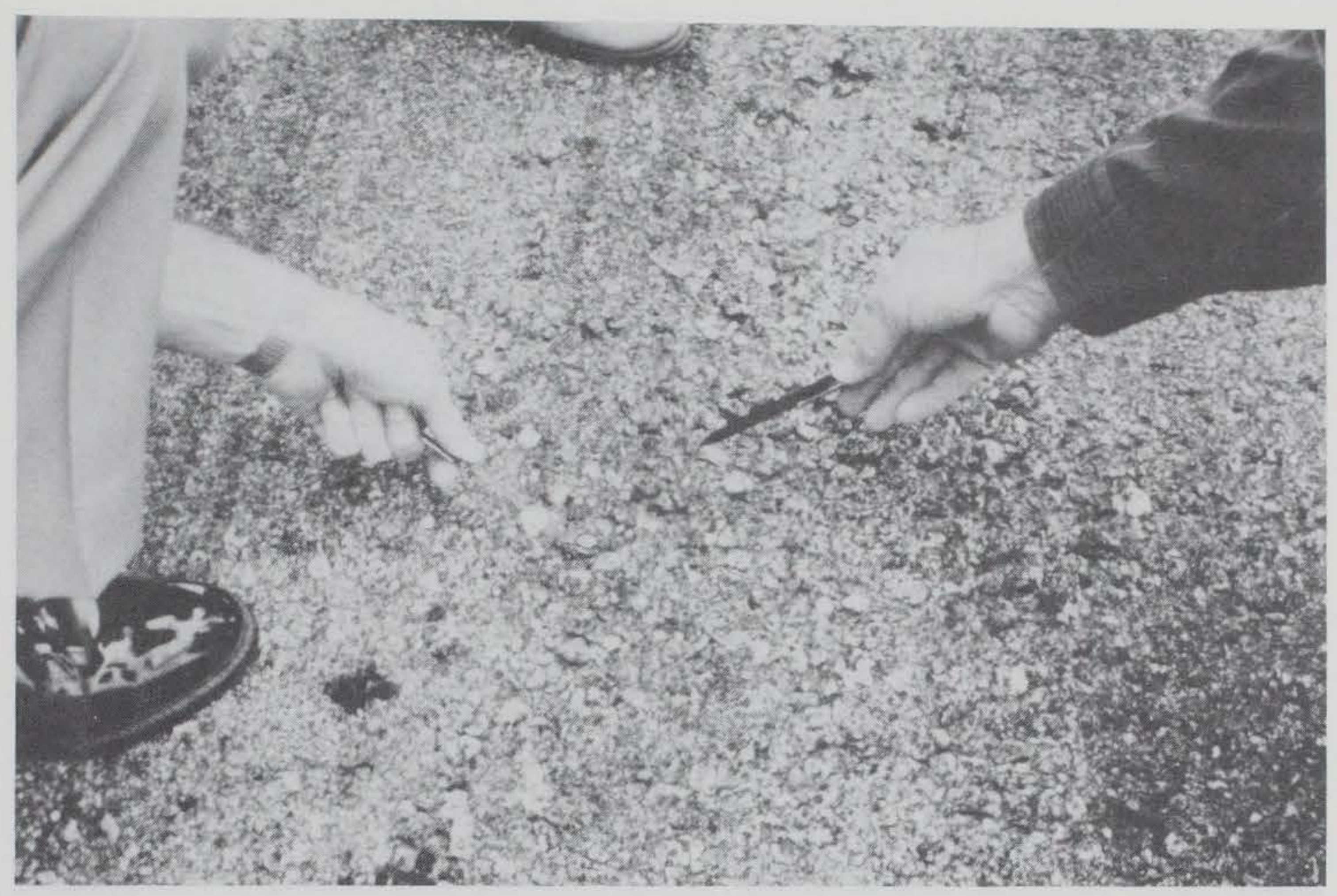

Figure 5. Medium raveling in nontraffic area

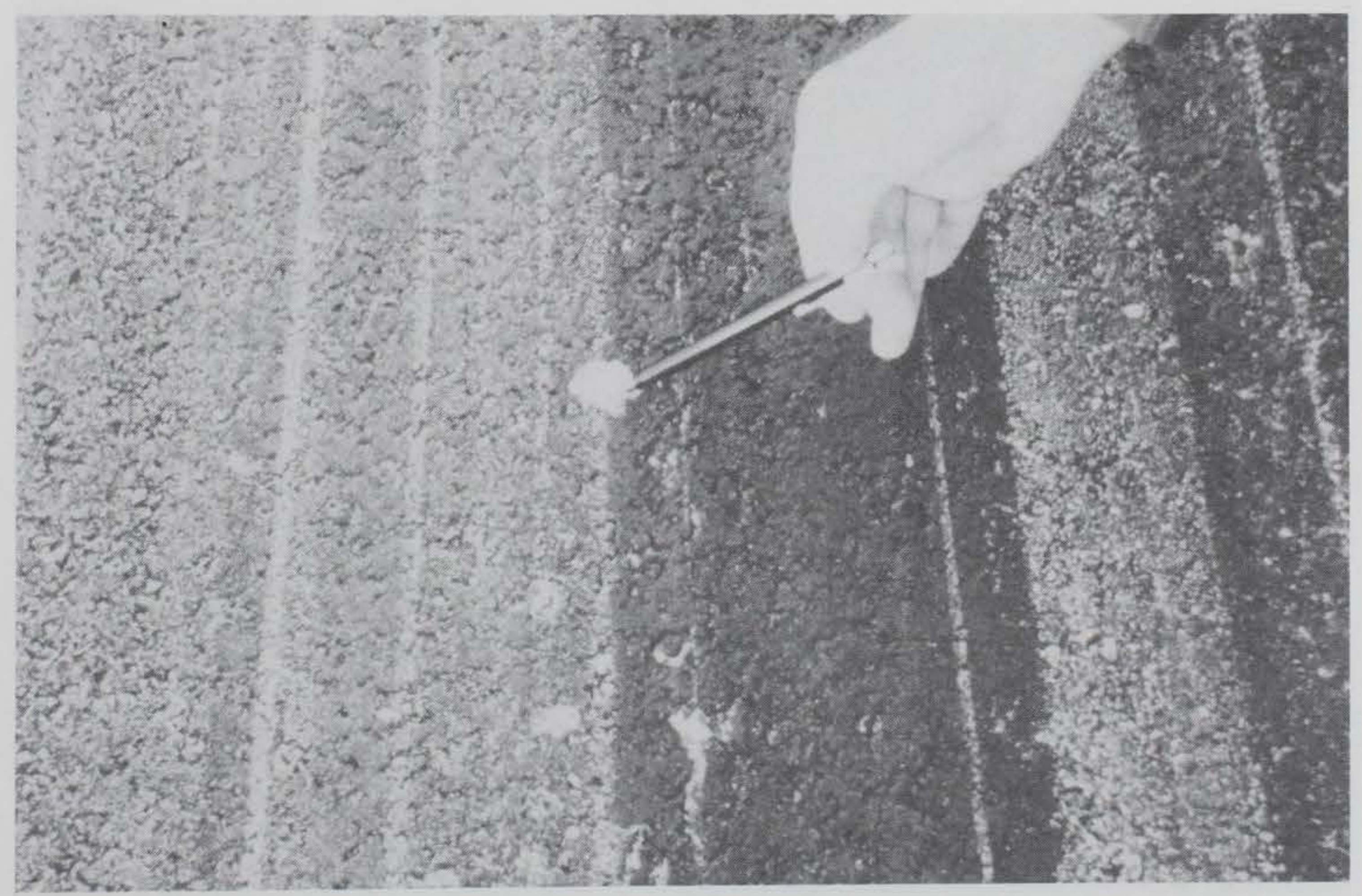

Figure 6. Exposed crushed limerock aggregate 


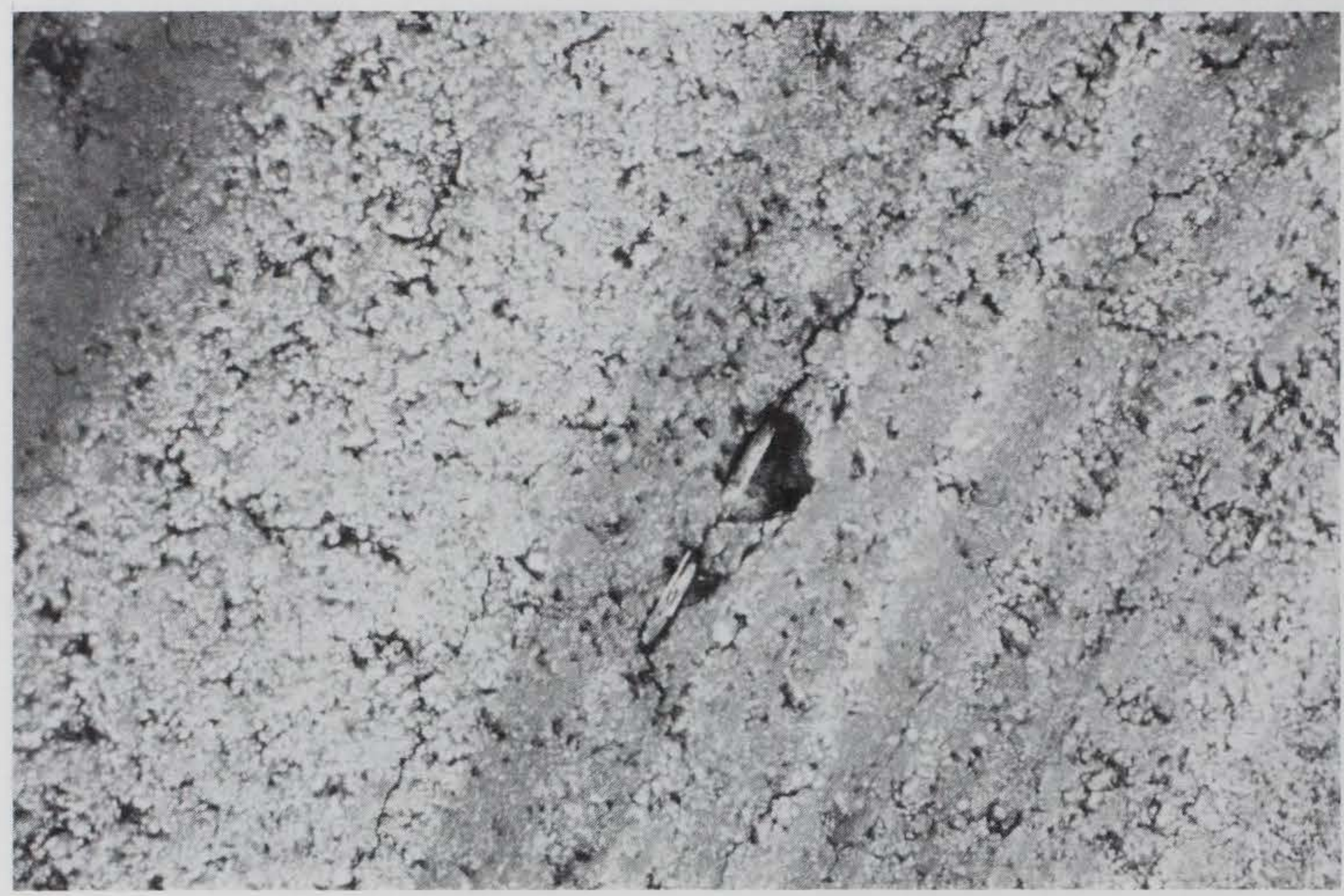

Figure 7. Typical root in asphalt

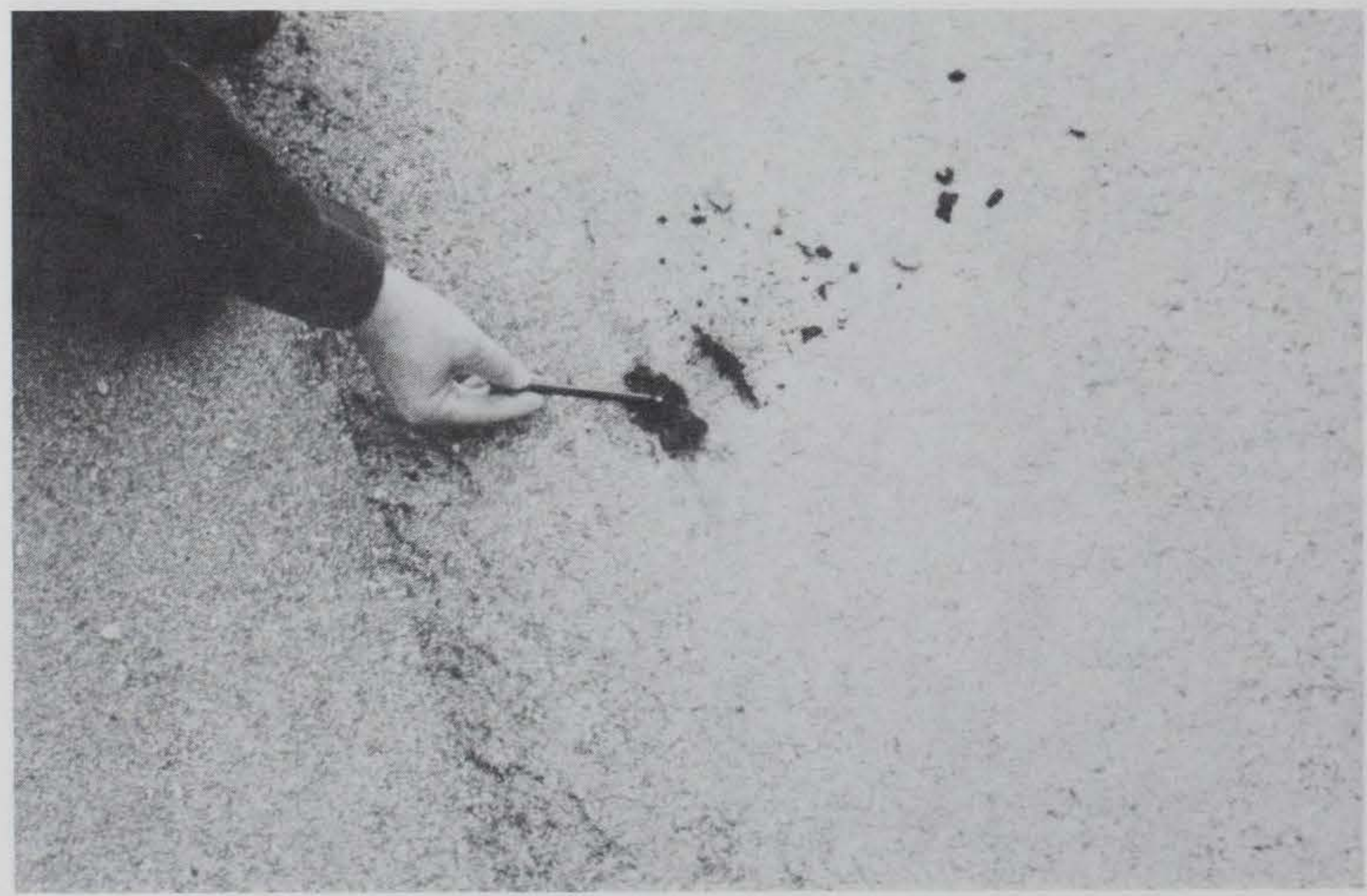

Figure 8. Uncoated fine aggregate beneath root (dirty natural sand) 


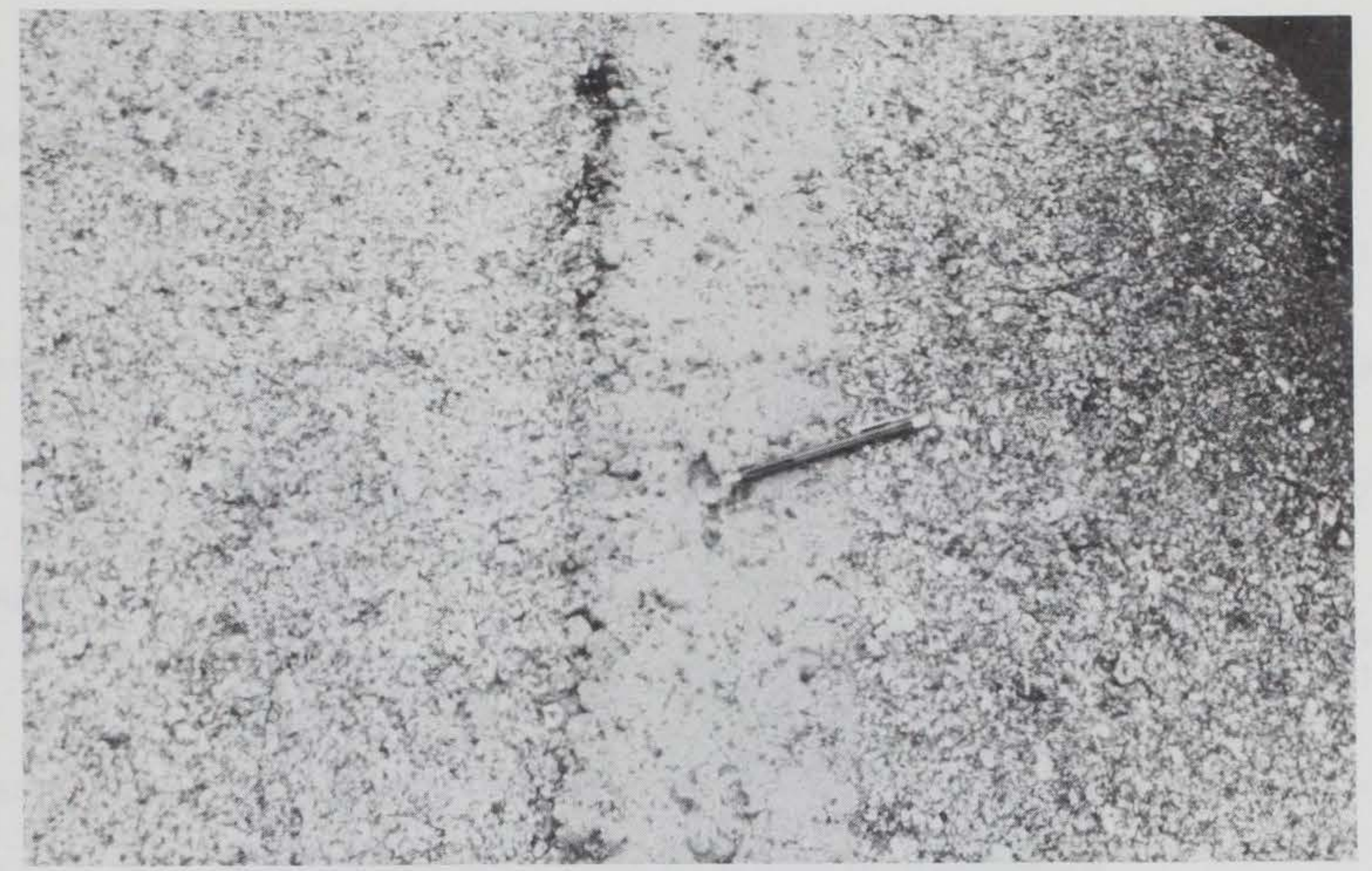

Figure 9. Open-textured asphalt concrete mixture beneath pavement marking

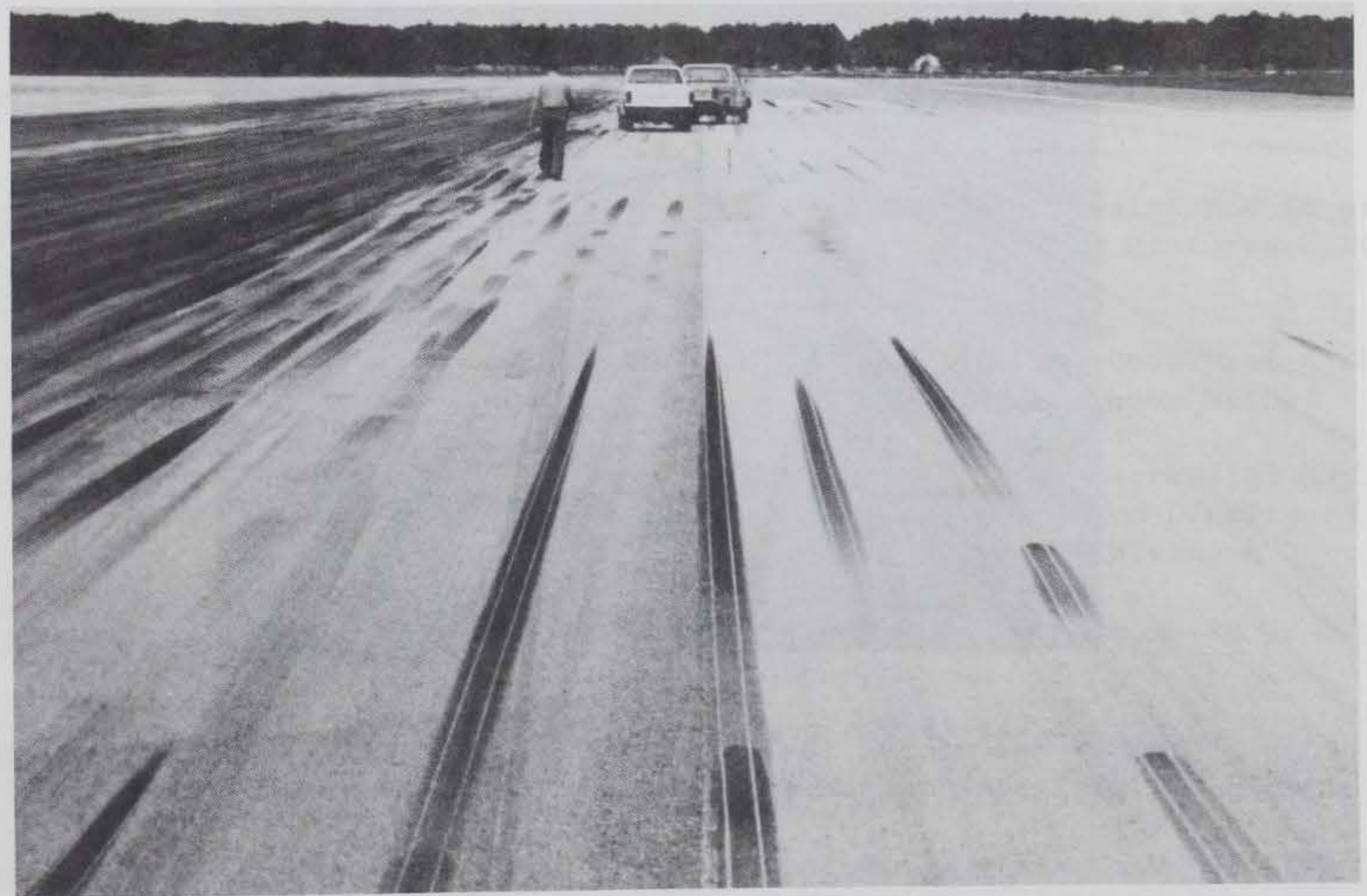

Figure 10. Two distinctive colors in asphalt concrete mixtures 


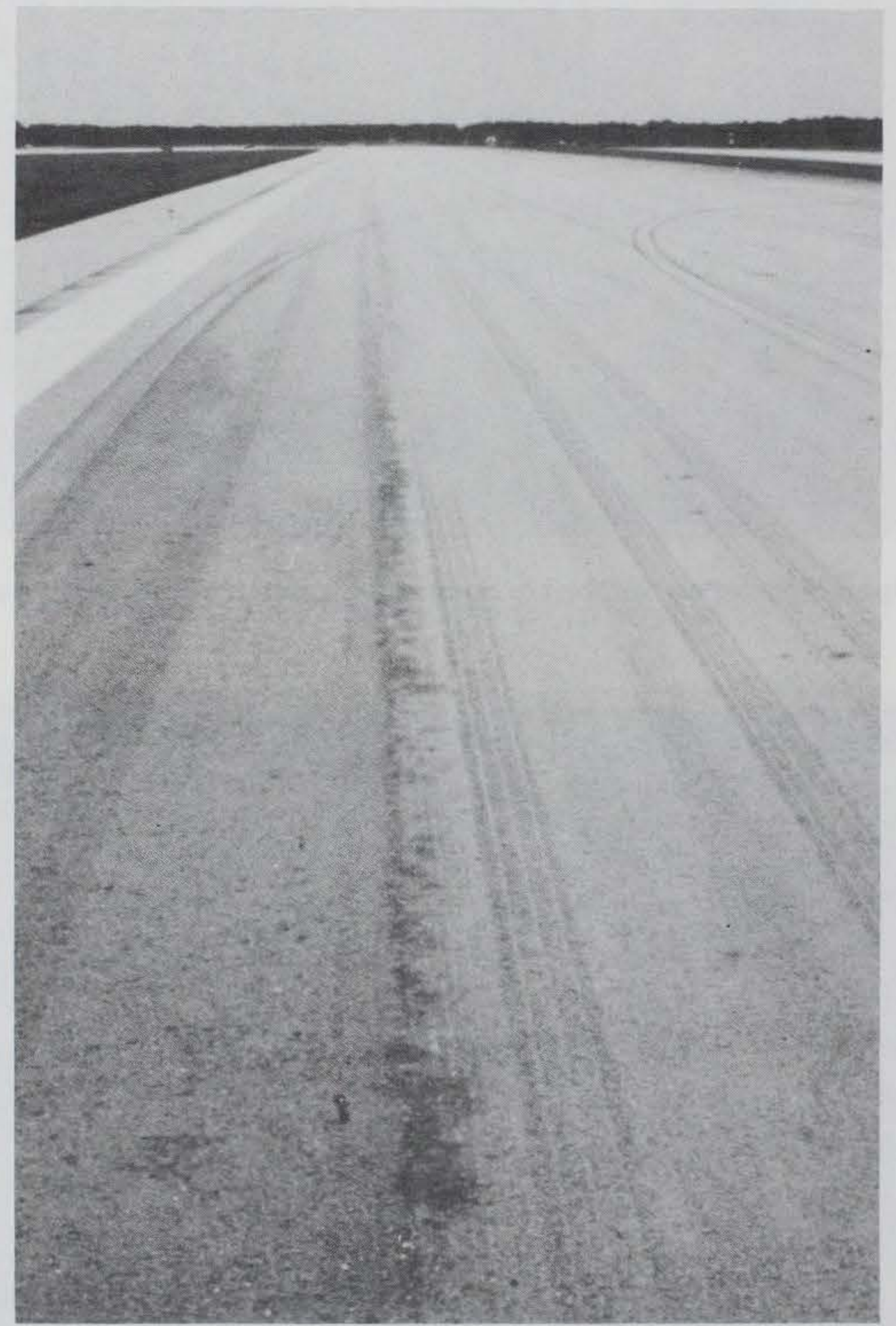

Figure 11. Brown stains alongside longitudinal joint 
Designation

ASTM C117

ASTM C127

ASTM C128

ASTM C131

ASTM C136

ASTM D5

ASTM D70

ASTM D113

ASTM D1559

ASTM D1856

ASTM D2041

ASTM D2170

ASTM D2171

ASTM D2171

\section{Title}

Test Method for Materials Finer than $75-\mu \mathrm{m}$ (No. 200) Sieve in Mineral Aggregates by Washing

Test Method for Specific Gravity and Absorption of Coarse Aggregate

Test Method for Specific Gravity and Absorption of Fine Aggregate

Test Method for Resistance to Degradation of Small-Size Coarse Aggregate by Abrasion and Impact in the Los Angeles Machine

Method for Sieve Analysis of Fine and Coarse Aggregate

Test Method for Penetration of Bituminous Materials

Test Method for Specific Gravity of Semi-Solid Bituminous Materials

Test Method for Dictility of Bituminous Materials

Test Method for Resistance to Plastsic Flow of Bituminous Mixtures Using Marshall Apparatus

Test Method for Recovery of Asphalt from Solution by Abson Method

Test method for Theoretical Maximum Specific Gravity and Density of Bituminous Paving Mixtures

Test Method for Kinematic Viscosity of Asphalts

Test Method for Viscosity of Asphalts by Vacuum Capillary Viscometer

Test methods for Quantitative Extraction of Bitumen from Bituminous Paving Mixtures 
ASTM D3387

ASTM D4867

MIL STD 620B, Method 100

MIL STD 620B, Method 101

MIL STD 620B, Method 104
Test Method for Compaction and Shear Properties of Bituminous Mixtures by Means of the U.S. Corps of Engineers Gyratory Testing Machine (GTM)

Test Method for Effect of Moisture on Asphalt Concrete Paving Mixtures

Unit Weight, Marshall Stability and Flow of Bituminous Mixtures

Density and Pe:-cent Voicis of Compacted Bituminous Paving Mixtures

Measurement of Reduction in Marshal1 Stability of Bituminous Mixtures

Caused by Immersion in Water 